\title{
ÆUSGS
}

science for a changing world

In cooperation with the Connecticut Department of Environmental Protection

\section{Nutrient Enrichment, Phytoplankton Algal Growth, and Estimated Rates of Instream Metabolic Processes in the Quinebaug River Basin, Connecticut, 2000-2001}

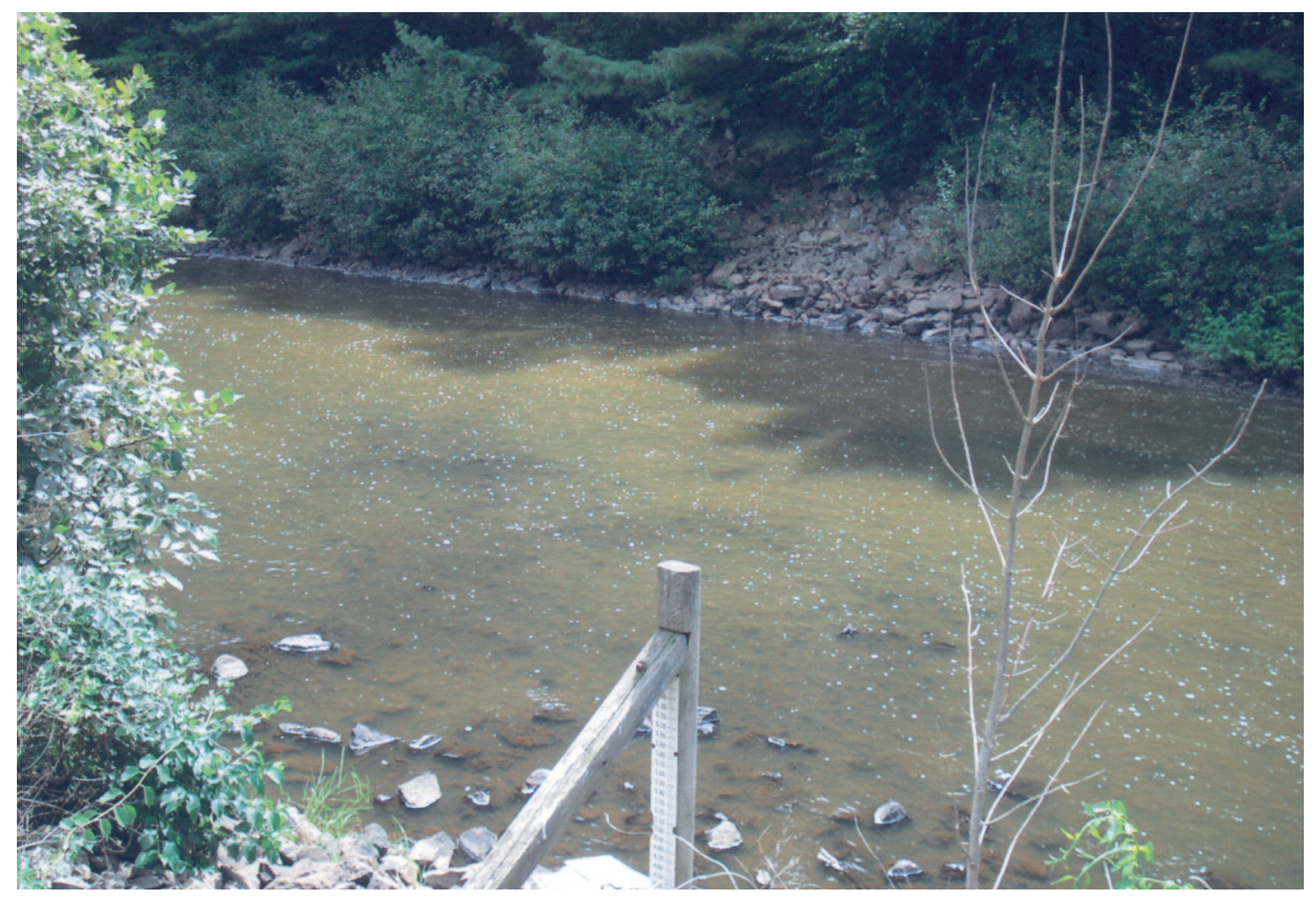

Scientific Investigations Report 2004-5227

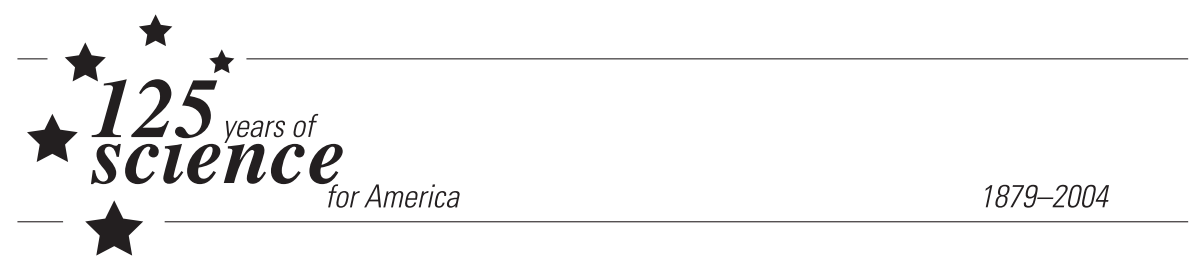

U.S. Department of the Interior

U.S. Geological Survey 
Cover.-Photograph showing the Quinebaug River at the outlet of West Thompson Lake, August 2003.

(Photograph by Jonathan Morrison, U.S. Geological Survey.) 


\section{Nutrient Enrichment, Phytoplankton Algal Growth, and Estimated Rates of Instream Metabolic Processes in the Quinebaug River Basin, Connecticut, 2000-2001}

By Michael J. Colombo, Stephen J. Grady, and Elaine C. Todd Trench

Scientific Investigations Report 2004-5227 


\title{
U.S. Department of the Interior Gale A. Norton, Secretary
}

\author{
U.S. Geological Survey \\ Charles G. Groat, Director
}

U.S. Geological Survey, Reston, Virginia: 2004

For sale by U.S. Geological Survey, Information Services

Box 25286, Denver Federal Center

Denver, CO 80225

\author{
For more information about the USGS and its products: \\ Telephone: 1-888-ASK-USGS \\ World Wide Web: http://www.usgs.gov/ \\ Any use of trade, product, or firm names in this publication is for descriptive purposes only and does not imply \\ endorsement by the U.S. Government. \\ Although this report is in the public domain, permission must be secured from the individual copyright owners to \\ reproduce any copyrighted materials contained within this report.
}




\section{Contents}

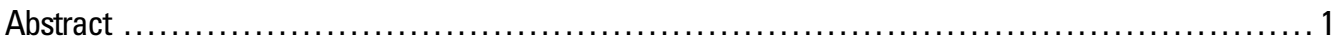

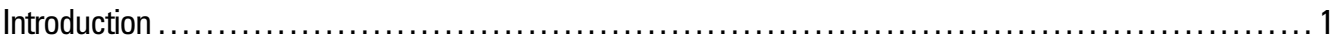

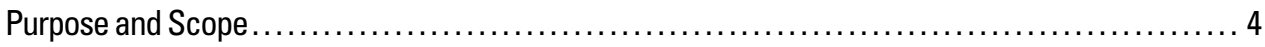

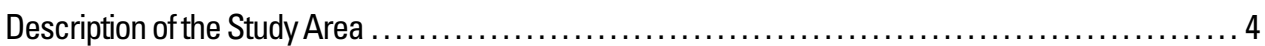

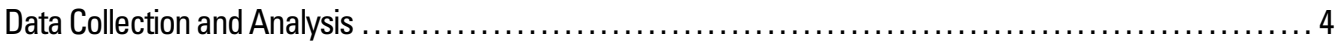

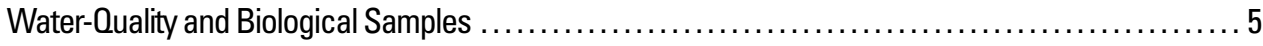

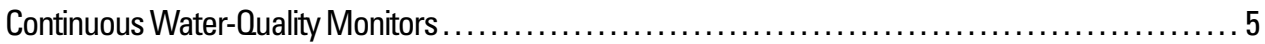

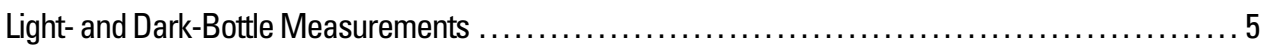

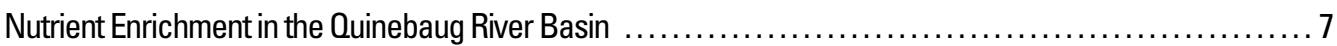

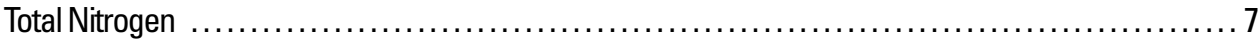

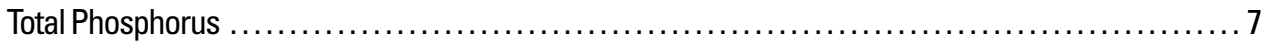

Correlation Between Total Nitrogen and Total Phosphorus ............................... 11

Effect of Nutrient Enrichment on Phytoplankton Algal Growth ................................ 11

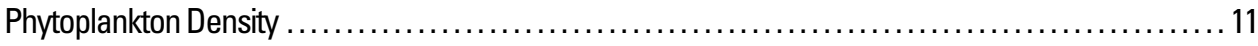

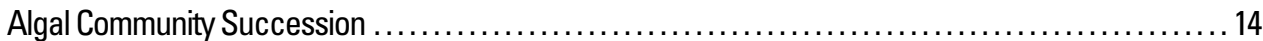

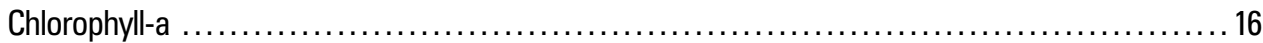

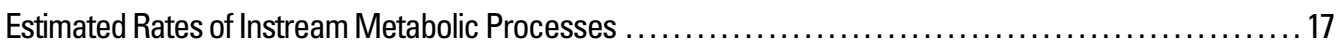

Rates Determined from Continuous Water-Quality Monitor Data $\ldots \ldots \ldots \ldots \ldots \ldots \ldots \ldots \ldots \ldots \ldots \ldots \ldots \ldots \ldots \ldots$

Rates Determined from Light- and Dark-Bottle Measurements .......................... 22

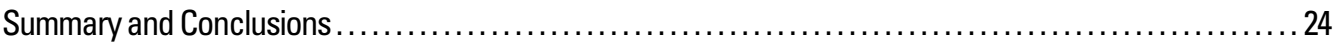

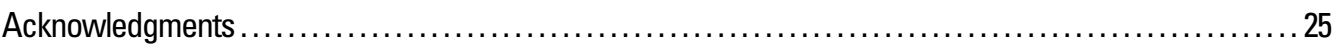

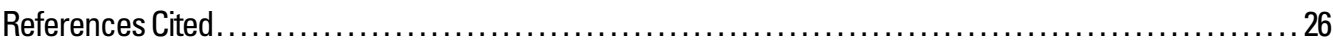

Appendix 1. Continuous water-quality monitor data and estimated maximum rates of instream metabolic processes at station 01124151, Quinebaug River at West Thompson, Conn. .................29

Appendix 2. Continuous water-quality monitor data and estimated maximum rates of instream metabolic processes at station 01125520, Quinebaug River at Cotton Bridge Road near Pomfret

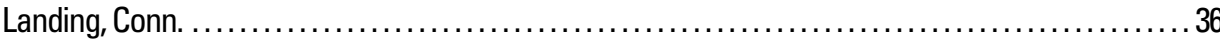

Appendix 3. Continuous water-quality monitor data and estimated maximum rates of instream metabolic processes at station 01126720, Quinebaug River near Packer, Conn...................... 44

Appendix 4. Continuous water-quality monitor data and estimated maximum rates of instream metabolic processes at station 01127000 , Quinebaug River at Jewett City, Conn....................... 50

Appendix 5. Seston algal abundance by taxa in water samples collected from the Quinebaug River Basin,

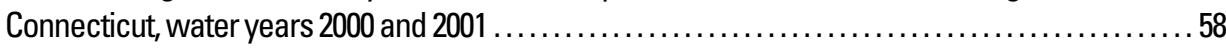

\section{Figures}

1. Map showing locations of U.S. Geological Survey stations, flood-control dams, and municipal wastewater-treatment plants in the Quinebaug River Basin, Connecticut....................2

2. Photograph showing summer algal bloom on the French River in Connecticut, August 20, 2002 .....3

3.-17. Graphs showing:

3. Streamflow at U.S. Geological Survey station 01125500, Quinebaug River at Putnam, Connecticut, indicating dates and flow conditions when water samples were collected,

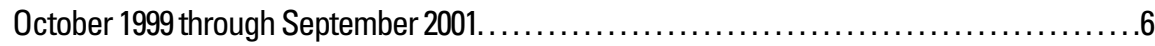


4. Concentration of total nitrogen at water-quality stations in the Quinebaug River Basin, October 1999 through September 2001..... .8

5. Relation between concentration of total nitrogen and streamflow for dates sampled during water years 2000 and 2001 at U.S. Geological Survey station 01125100, French River near North Grosvenordale, Connecticut.

6. Concentrations of total phosphorus at water-quality stations in the Quinebaug River Basin, October 1999 through September 2001.

7. Cumulative distribution of total phosphorus concentrations in water samples collected during water years 2000 and 2001 from stations in the Quinebaug River Basin in relation to probable phosphorus sources.

8. Concentration of total nitrogen plotted against concentration of total phosphorus in water samples collected during water years 2000 and 2001 from stations in the Quinebaug River Basin, Connecticut, in relation to probable nutrient sources

9. Long-term median monthly streamflow plotted against monthly mean streamflow during the growing seasons of water years 2000 and 2001 for U.S. Geological Survey station 01125500, Quinebaug River at Putnam, Connecticut.

10. Mean daily streamflow during the growing seasons of water years 2000 and 2001 for U.S. Geological Survey station 01125500, Quinebaug River at Putnam, Connecticut......... 14

11. Seston algal communities in the Quinebaug River at West Thompson, Connecticut, during the summers of 2000 and 2001

12. Relation of concentration of seston chlorophyll-a to phytoplankton algal abundance in the Quinebaug River Basin, Connecticut, October 1999 through September 2001......... 16

13. Concentrations of chlorophyll-a in the Quinebaug River and tributary streams, Connecticut, October 1999 through September 2001

14. Determination of the maximum estimated rate of primary productivity and respiration from continuous monitor dissolved oxygen data at U.S. Geological Survey station 01125520, Quinebaug River at Cotton Bridge Road near Pomfret Landing, Connecticut ...... 18

15. Estimated maximum primary productivity and streamflow of the Quinebaug River at U.S. Geological Survey station 01125520, Cotton Bridge Road near Pomfret Landing, Connecticut,, showing (A) variability with discharge and (B) variability with time.

16. Effects of streamflow regulation on concentrations of dissolved oxygen at U.S. Geological Survey station 01127000, Quinebaug River at Jewett City, Connecticut....

17. Ratio of estimated maximum primary productivity rate (Pmax) to estimated maximum respiration rate (Rmax) during water years 2000 and 2001 at four stations in the Quinebaug River Basin, Connecticut.

\section{Tables}

1. Sampling sites and types of data collected in the Quinebaug River Basin, Connecticut, water years 2000 and 2001.

2. Phytoplankton density at sampling locations in the Quinebaug River Basin, Connecticut, water years 2000 and 2001.

3. Primary productivity and respiration estimated from continuous monitors at sampling locations in the Quinebaug River Basin, Connecticut, water years 2000 and 2001.

4. Primary productivity and respiration estimated from light and dark bottles at sampling locations in the Quinebaug River Basin, Connecticut, water year 2001. 


\section{Conversion Factors, Vertical Datum, and Abbreviations}

\begin{tabular}{lcl}
\hline Multiply & By & To obtain \\
\hline & Length & \\
foot (ft) & 0.3048 & meter \\
mile (mi) & 1.609 & kilometer \\
& Area & \\
square mile $\left(\mathrm{mi}^{2}\right)$ & 2.590 & square kilometer \\
& Flow rate & \\
cubic foot per second $\left(\mathrm{ft}^{3} / \mathrm{s}\right)$ & 0.02832 & cubic meter per second \\
cubic foot per second per & & cubic meter per second per \\
square mile $\left(\mathrm{ft}^{3} / \mathrm{s} / \mathrm{mi}^{2}\right)$ & 0.01093 & square kilometer \\
\hline
\end{tabular}

Temperature in degrees Celsius $\left({ }^{\circ} \mathrm{C}\right)$ may be converted to degrees Fahrenheit $\left({ }^{\circ} \mathrm{F}\right)$ as follows: ${ }^{\circ} \mathrm{F}=\left(1.8 \times{ }^{\circ} \mathrm{C}\right)+32$

Temperature in degrees Fahrenheit $\left({ }^{\circ} \mathrm{F}\right)$ may be converted to degrees Celsius $\left({ }^{\circ} \mathrm{C}\right)$ as follows: ${ }^{\circ} \mathrm{C}=\left({ }^{\circ} \mathrm{F}-32\right) / 1.8$

Vertical coordinate information is referenced to the North American Vertical Datum of 1988 (NAVD 88). Horizontal coordinate information is referenced to the North American Datum of 1927 (NAD 27).

Concentration of chemical constituents is given in milligrams per liter $(\mathrm{mg} / \mathrm{L})$ or micrograms per liter $(\mu \mathrm{g} / \mathrm{L})$.

Primary productivity is expressed as a rate of change in either a positive (increasing) or negative (decreasing) direction in grams of oxygen per cubic meter per hour $\left(\mathrm{g} \mathrm{O}_{2} / \mathrm{m}^{3} / \mathrm{hr}\right.$ ).

Phytoplankton density is given in algal cells per milliliter $(\mathrm{c} / \mathrm{mL})$. 



\title{
Nutrient Enrichment, Phytoplankton Algal Growth, and Estimated Rates of Instream Metabolic Processes in the Quinebaug River Basin, Connecticut, 2000-2001
}

\author{
by Michael J. Colombo, Stephen J. Grady, and Elaine C. Todd Trench
}

\section{Abstract}

A consistent and pervasive pattern of nutrient enrichment was substantiated by water-quality sampling in the Quinebaug River and its tributaries in eastern Connecticut during water years 2000 and 2001. Median total nitrogen and total phosphorus concentrations exceeded the U.S. Environmental Protection Agency's recently recommended regional ambient water-quality criteria for streams ( 0.71 and 0.031 milligrams per liter, respectively). Maximum total phosphorus concentrations exceeded 0.1 milligrams per liter at nearly half the sampled locations in the Quinebaug River Basin. Elevated total nitrogen and total phosphorus concentrations were measured at all stations on the mainstem of the Quinebaug River, the French River, and the Little River. Nutrient enrichment was related to municipal wastewater point sources at the sites on the mainstem of the Quinebaug River and French River, and to agricultural nonpoint nutrient sources in the Little River Basin.

Nutrient enrichment and favorable physical factors have resulted in excessive, nuisance algal blooms during summer months, particularly in the numerous impoundments in the Quinebaug River system. Phytoplankton algal density as high as 85,000 cells per milliliter was measured during such nuisance blooms in water years 2000 and 2001. Different hydrologic conditions during the summers of 2000 and 2001 produced very different seston algal populations. Larger amounts of precipitation sustained higher streamflows in the summer of 2000 (than in 2001), which resulted in lower total algal abundance and inhibited the typical algal succession from diatoms to cyanobacteria. Despite this, nearly half of all seston chlorophyll-a concentrations measured during this study exceeded the recommended regional ambient stream-water-quality criterion $(3.75$ micrograms per liter), and seston chlorophyll-a concentrations as large as 42 micrograms per liter were observed in wastewater-receiving reaches of the Quinebaug River.

Estimates of primary productivity and respiration obtained from diel dissolved oxygen monitoring and from light- and dark-bottle dissolved oxygen measurements demonstrated that instream metabolic processes are consistent with a seston-algae dominant system. The highest estimated maximum primary productivity rate was 1.72 grams of oxygen per cubic meter per hour at the Quinebaug River at Jewett City during September 2001. The observed extremes in diel dissolved oxygen concentrations (less than 5 milligrams per liter) and $\mathrm{pH}$ (greater than 9) may periodically stress aquatic organisms in the Quinebaug River Basin.

\section{Introduction}

Phosphorus and nitrogen are essential nutrients for plant growth; however, excessive concentrations of both nutrients have been reported historically at water-quality monitoring stations in the Quinebaug River Basin that are operated cooperatively by the Connecticut Department of Environmental Protection (CTDEP) and the U.S. Geological Survey (USGS).

Nitrogen availability rarely limits aquatic plant growth in freshwater, whereas phosphorus concentrations in natural or nearnatural streams are generally low enough to limit plant growth. Excessive phosphorus concentrations in freshwater promote growth of aquatic algae and eutrophic conditions (Hem, 1985; Litke, 1999). National criteria have not been established for concentrations of phosphorus compounds in streams; however, to control eutrophication, the U.S. Environmental Protection Agency (USEPA) (1986) has recommended that total phosphorus not exceed $0.05 \mathrm{mg} / \mathrm{L}$ (milligrams per liter) in a stream at a point where it enters a lake or reservoir and not exceed $0.1 \mathrm{mg} /$ L in flowing waters. More recently, the USEPA has presented a national strategy to develop regional nutrient criteria (U.S. Environmental Protection Agency, 1998) and has recommended an ambient water-quality criterion of $0.031 \mathrm{mg} / \mathrm{L}$ of total phosphorus as the aggregate reference condition for rivers and streams in the Eastern Coastal Plain ecogregion, which includes Connecticut (U.S. Environmental Protection Agency, 2000a).

Municipal wastewater containing high levels of phosphorus and nitrogen is discharged to the Quinebaug River and its tributaries (Medalie, 1996; Trench, 2000) at numerous locations in Connecticut and Massachusetts (fig. 1). Municipal wastewater return flows constituted approximately 1.3 to 2.4 percent of the annual mean streamflow of the Quinebaug River (measured at USGS streamflow-gaging stations at Quinebaug and at Jewett City, Connecticut) in the early to mid-1990's (Trench, 2000). Improvements in wastewater treatment and the decline in the manufacture and use of detergents containing phosphorus probably have contributed to the significant decline in total phosphorus concentrations observed in many Connecticut streams, including the Quinebaug River, from the 1970's to the 1990's (Trench, 1996; 2000; Colombo and Trench, 2002). Litke (1999) reported that total phosphorus concentrations in municipal wastewater have declined nationally from about $11 \mathrm{mg} / \mathrm{L}$ during the height of phosphate detergent use in the 1970's to about $5 \mathrm{mg} / \mathrm{L}$ in the late 1990's. Despite the improvements in wastewater treatment and significant long-term downward trends in 


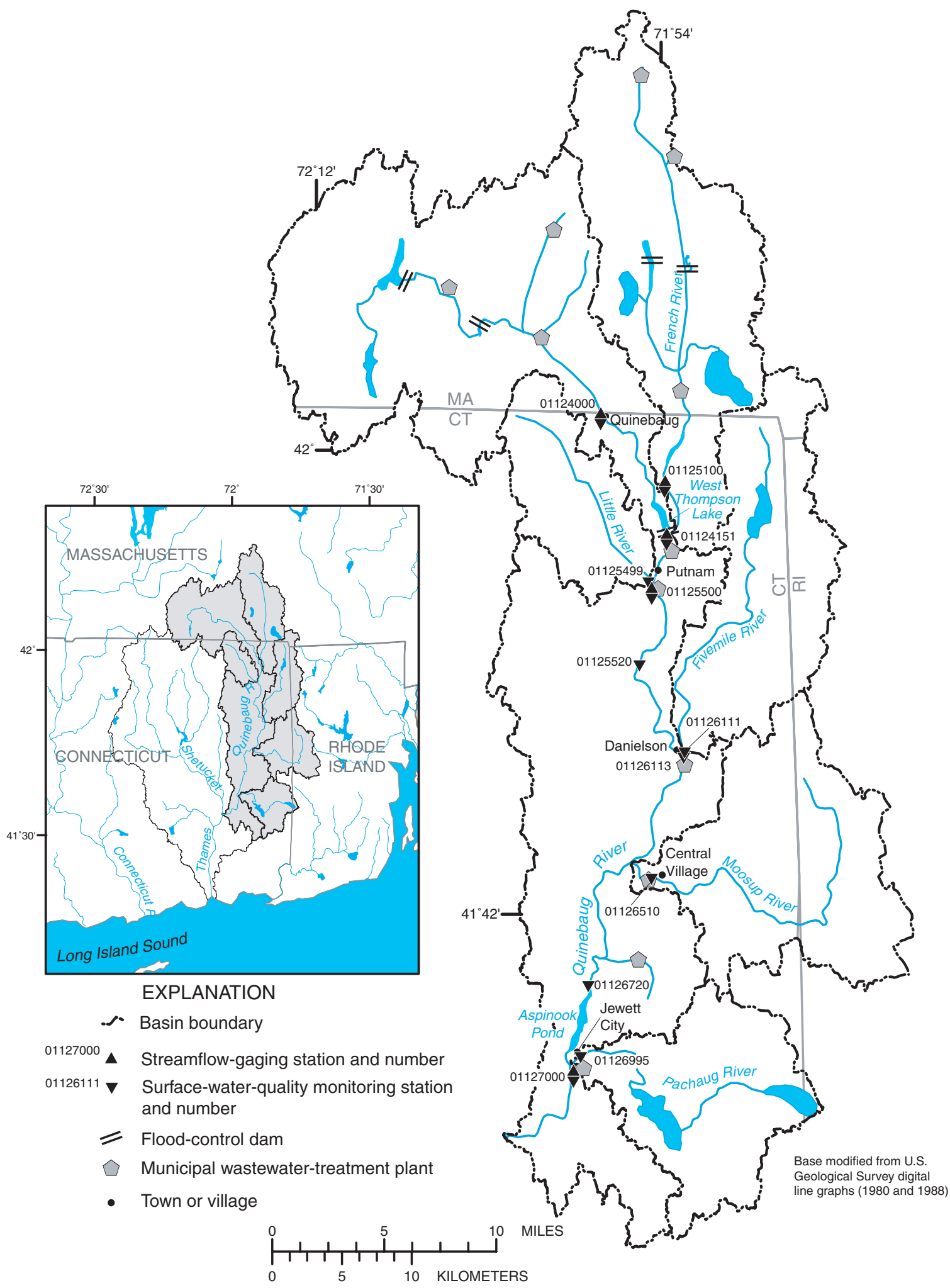

Figure 1. Locations of U.S. Geological Survey stations, flood-control dams, and municipal wastewater-treatment plants in the Quinebaug River Basin, Connecticut. 
phosphorus concentrations in the Quinebaug River, current concentrations of total phosphorus are substantially higher than those that would be found under natural or near-natural conditions in Connecticut. Total phosphorus concentrations in excess of $0.1 \mathrm{mg} / \mathrm{L}$ are still measured along many reaches of the Quinebaug River and some of its tributaries (Morrison and others, 2003), and eutrophic conditions with nuisance algal blooms have been observed during summer and fall months in several impoundments and slackwater reaches of the Quinebaug River and its tributaries (fig. 2).

Several impoundments and stream reaches in the Quinebaug River Basin have been listed repeatedly as not meeting standards of the Federal Clean Water Act because of elevated nutrient and chlorophyll-a concentrations, excessive algal growth, and persistent organic enrichment causing high levels of biochemical oxygen demand and low levels of dissolved oxygen (Connecticut Department of Environmental Protection, 1994; 1998a; 2002). Furthermore, the affected impoundments and river reaches of the Quinebaug River and its tributaries may store and release nutrients and algae and serve as "point sources" for downstream stream reaches under some conditions. High levels of biochemical oxygen demand in the upper reaches of the Thames River Estuary have been attributed to downstream transport of high concentrations of nutrients and algae originating in the Quinebaug River Basin (T. Nelson, Connecticut Department of Environmental Protection, written commun., 1998).

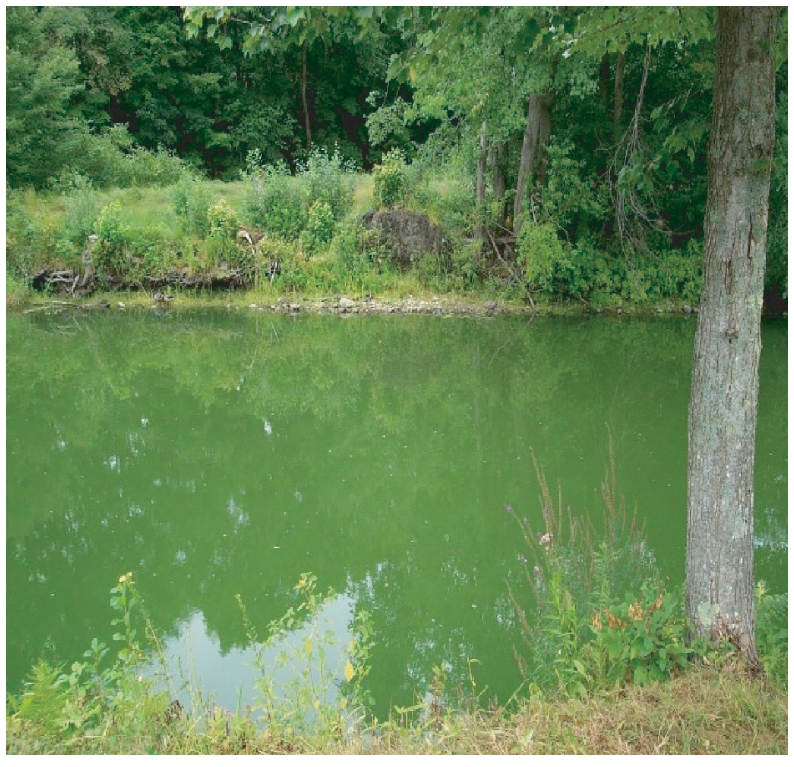

Figure 2. Summer algal bloom on the French River in Connecticut, August 20, 2002. (Photograph by S. Lyle Phipps, USGS.)
Algae are single-celled plants that contain chlorophyll and carry out photosynthesis. Nutrient enrichment can promote excessive growth of two types of algae: (1) phytoplankton, algae suspended in lakes and reservoirs and sometimes in slowflowing rivers and streams, and (2) periphyton, algae attached to some submerged substrate. Seston refers to the algae transported in the river or stream and includes both the suspended phytoplankton plus any periphyton that have been dislodged. Algae decompose when they die, consuming oxygen in the water and contributing to a condition called hypoxia. Hypoxia occurs when dissolved oxygen levels are depleted to such a degree that the viability of aquatic life is affected. Low concentrations of dissolved oxygen in the Thames River have been reported by the CTDEP during summer and fall periods coinciding with or following periods of observed high concentrations of nutrients and nuisance algae blooms in the Quinebaug River Basin (E. Pizzuto, Connecticut Department of Environmental Protection, oral commun., 2001).

The diurnal metabolic cycle of aquatic plants and animals can produce fluctuations in nutrient concentrations and affect water-quality conditions, as measured by parameters such as specific conductance, $\mathrm{pH}$, dissolved oxygen, and carbon dioxide. During the day, photosynthetic activity of aquatic plants, including algae, removes carbon dioxide and releases oxygen to the stream. At night, photosynthesis ceases while aquatic plants and animals continue to respire and consume oxygen. Continuous water-quality monitoring records for water temperature, $\mathrm{pH}$, specific conductance, and dissolved oxygen collected in the Quinebaug River during 2000 and 2001 show that $\mathrm{pH}$ and dissolved oxygen levels vary on a diurnal basis. The cause of this diel activity is believed to be associated with excess algal plant growth due to nutrient enrichment.

Understanding where, when, and how elevated nutrient concentrations affect the rate of primary productivity in the Quinebaug River Basin may facilitate decisions by waterresource managers on how best to manage the water resources to minimize nuisance algal blooms. This may involve lowering maximum productivity rates and decreasing the length of time during which the blooms occur. As part of the continuing effort to understand and improve water quality in Connecticut, the CTDEP and the USGS began a cooperative multi-part study in 2000 to (1) characterize the relation between nutrient enrichment and excessive algal productivity in the Quinebaug River Basin, (2) analyze long-term trends for total phosphorus in the Quinebaug River Basin and evaluate optimal sampling designs for monitoring future trends, (3) review the current level of understanding of nutrient-related water-quality problems in the Thames River Basin, and (4) develop a science plan to direct water-quality investigations needed to manage and restore aquatic resources. Results from the first objective of the study, relating to nutrient concentrations in the Quinebaug River Basin and the effects of nutrient enrichment on algal growth, are reported here. 


\section{Purpose and Scope}

This report presents information on nutrient concentrations in the Quinebaug River and several tributaries in eastern Connecticut during water years ${ }^{1} 2000$ and 2001 (October 1999 through September 2001) and relates the location and timing of elevated nutrient concentrations to the occurrence of elevated seston chlorophyll-a concentrations and pronounced increases in seston algal populations. The report also provides estimated rates of primary productivity and respiration of seston algal communities using both diel curves of dissolved oxygen concentrations measured at continuous water-quality monitors and in light- and dark-bottle samples. On the basis of the primary productivity and respiration rates determined from the lightand dark-bottle method, this report also characterizes parts of the main stem and tributary rivers as either seston- or periphyton-dominated systems.

\section{Description of the Study Area}

The Quinebaug River drains $740 \mathrm{mi}^{2}$ (square miles) in eastern Connecticut, western Rhode Island, and south-central Massachusetts and is a major tributary to the Shetucket River, which flows into the Thames River Estuary at the eastern end of Long Island Sound (fig. 1). The principal tributaries of the Quinebaug River, listed from north to south, are the French, Little, Fivemile, Moosup, and Pachaug Rivers. The Quinebaug River and some of its tributaries were used at numerous locations in the basin for industrial water power to supply $18^{\text {th }}$ - and $19^{\text {th }}$-century mills. Numerous dams and associated structures were located throughout the watershed and many of these remain, some still producing hydroelectric power. Additional dams were constructed by the U.S. Army Corps of Engineers for flood control following widespread floods in 1938 and 1955. With numerous impoundments along the main stem and its tributaries (fig. 1), streamflow in the Quinebaug River is highly regulated.

Land use in the Quinebaug River Basin is primarily forest (68 percent) and agriculture (12 percent). Scattered small urban areas are mostly along the main stem and upper tributaries where villages and towns were built around an economy dominated by textile mill works. Urban land use encompasses about 8 percent of the watershed including the historic small urban centers and newer suburban developments that are more often found in upland areas. The remaining area includes water or wetlands and other minor land uses. The current and historic land-use patterns have affected various segments of the basin with point- and nonpoint-source pollution from municipal and industrial wastewater discharges, urban runoff, and agricultural practices.

\section{Data Collection and Analysis}

Water-quality and biological samples were collected at 12 USGS stations during water years 2000 and 2001. The stations sampled included seven sites along the main stem of the Quinebaug River and five sites on tributaries to the Quinebaug River. The distribution, type, and period of record for the data used in this report are summarized in table 1.

\footnotetext{
${ }^{1} \mathrm{~A}$ water year is defined as the 12-month period October 1 through September 30 . The water year is designated by the calendar year in which it ends and which includes 9 of the 12 months. Thus, the year ending September 30, 2001 is called the 2001 water year.
}

Table 1. Sampling sites and types of data collected in the Quinebaug River Basin, Connecticut, water years 2000 and 2001.

$[\mathrm{CM}$, continuous water-quality monitoring for dissolved oxygen, $\mathrm{pH}$, specific conductance, and water temperature; TN, total nitrogen; TP, total phosphorus; TOC, total organic carbon; CHLa, chlorophyll-a; PA, phytoplankton analysis; LD, light- and dark-bottle productivity]

\begin{tabular}{|c|c|c|c|c|c|c|c|c|}
\hline \multicolumn{2}{|r|}{ U.S. Geological Survey station } & \multicolumn{7}{|c|}{ Type of data collected and number of days of data or number of samples } \\
\hline Number & Name & $\mathrm{CM}$ & TN & TP & TOC & CHLa & PA & LD \\
\hline 01124000 & Quinebaug River at Quinebaug, Conn. & 0 & 34 & 34 & 22 & 19 & 6 & 0 \\
\hline 01125100 & French River near North Grosvenordale, Conn. & 0 & 34 & 34 & 21 & 18 & 6 & 1 \\
\hline 01125499 & Little River at Putnam, Conn. & 0 & 20 & 20 & 5 & 18 & 6 & 1 \\
\hline 01125500 & Quinebaug River at Putnam, Conn. & 0 & 37 & 37 & 6 & 18 & 6 & 1 \\
\hline 01126111 & Fivemile River at Danielson, Conn. & 0 & 18 & 18 & 4 & 18 & 6 & 0 \\
\hline 01126113 & Quinebaug River at Danielson, Conn. & 0 & 18 & 18 & 4 & 18 & 7 & 1 \\
\hline 01126510 & Moosup River at Plainfield, Conn. & 0 & 18 & 18 & 4 & 18 & 6 & 1 \\
\hline 01126720 & Quinebaug River near Packer, Conn. & 217 & 20 & 20 & 6 & 18 & 7 & 1 \\
\hline 01126995 & Pachaug River at Jewett City, Conn. & 0 & 18 & 18 & 5 & 17 & 7 & 1 \\
\hline
\end{tabular}




\section{Water-Quality and Biological Samples}

At most stations, water-quality samples were collected from October 1999 through September 2001 (fig. 3) to characterize the areal and temporal distribution of nutrient concentrations and loads in various reaches of the Quinebaug River Basin. Total nitrogen was determined as the sum of analytically determined dissolved nitrite-plus-nitrate nitrogen and total ammonia-plus-organic nitrogen concentrations. Total phosphorus was analytically determined by a Kjeldahl digestion method. Nutrient samples were collected year-round at most sites, although the sampling frequency increased from monthly during the fall and winter to biweekly during the spring and summer (fig. 3). Also, sampling was begun in the fall of 1999 at 5 of the sites but not until the spring of 2000 at 7 others; consequently, the number of total nitrogen and total phosphorus samples ranged from as few as 18 to as many as 37 among the 12 stations (table 1).

Biological data collection included seston samples for phytoplankton enumeration and identification, and determination of chlorophyll-a concentrations. Biological data were collected only during the growing seasons of 2000 and 2001 (fig. 3 ). Limited phytoplankton sampling was conducted to document the number and identification of seston algae in the Quinebaug River and tributaries at selected dates before, during, and (or) after observed nuisance algal blooms. Generally, six or seven phytoplankton samples were collected in May, July, and (or) September 2000 and June, August, and September 2001 at each of the 12 sites sampled (table 1). Chlorophyll-a samples were collected with all phytoplankton samples and with most biweekly summer water-quality samples to estimate algal enrichment at the sampling sites when phytoplankton samples were not collected (fig. 3). Between 17 and 19 seston chlorophyll-a samples were collected at each station during this study (table 1). Total organic carbon (TOC) samples can be used as an indirect indicator of algal enrichment, but other sources of organic carbon (industrial and municipal wastewater effluents) are likely contributors to elevated TOC concentrations in waste-receiving streams. TOC samples were collected at all 12 sites; however, only 4 of the sites in the Quinebaug River Basin were sampled frequently for TOC (table 1).

In addition to the water-quality and biological sampling described above, treated effluent wastewater samples were collected during the summer of 2001 at four municipal wastewatertreatment plants to characterize the nutrient content of wastewater that is discharged to the Quinebaug River. Ten samples were collected from the outfall of each plant and analyzed for the same nutrient constituents as the surface-water samples.

All water-quality samples, seston chlorophyll-a, and phytoplankton samples were collected in accordance with USGS approved methods and protocols (Britton and Greeson, 1989; Ward and Harr, 1990; Shelton, 1994; Wilde and Radtke, 1998; and, Moulton and others, 2002). Water-quality (and effluent) samples were processed (filtered and preserved as appropriate), chilled, and shipped for analysis at the USGS National Water Quality Laboratory (NWQL) in Denver, Colorado. The NWQL performed all analyses for nutrients, carbon, and chlorophyll-a included in this report; analytical methods used by the NWQL are described in USGS reports (Wershaw and others, 1987; Britton and Greeson, 1989; Fishman and Friedman, 1989; Patton and Truitt, 1992; Brenton and Arnett, 1993; and Fishman, 1993). Samples obtained for seston (phytoplankton) analyses were collected generally on the same day as water-quality samples and were chilled and delivered to the CTDEP laboratory in Hartford, Connecticut. Phytoplankton enumeration (SedgwickRafter cell counts) and identification were conducted in accordance with protocols described by the American Public Health Association (1992).

\section{Continuous Water-Quality Monitors}

Continuous water-quality monitors were deployed at four sites in the Quinebaug River to collect dissolved oxygen concentration, $\mathrm{pH}$, water temperature, and specific conductance data at 15-minute intervals. Daily maximum and minimum values are reported in appendixes 1 to 4 . The monitors were intended to collect data throughout the period of each water year when solar insolation is greatest and most aquatic plant growth occurs (generally May through September). Additionally, in the first year of the study, continuous data also were collected during the period of declining solar insolation during fall and early winter (October to December). Installation, maintenance, calibration, cleaning, and record computation were done in accordance with USGS guidelines and standard procedures (Wagner and others, 2000). Some record was lost at each station, however, because of operational problems including battery, probe fouling, and instrument failures; hence, the number of days with continuous monitor data ranged from 217 for station 01126720 (appendix 3) to 305 at station 0112700 (appendix 4). Dissolved oxygen data were the most problematic of the continuous-monitor measurements, and the number of days with complete daily dissolved oxygen record varied from 102 to 185 days at the four sites in water year 2000. Operational problems also severely limited data collection at two sites in 2001 such that only 40 days of dissolved oxygen data were collected at station 01126720 (appendix 3), and just 6 days of data were recorded at station 01124151(appendix 1).

\section{Light- and Dark-Bottle Measurements}

Standard light- and dark-bottle metabolic-rate measurements (Britton and Greeson, 1989; American Public Health Service, 1992) were conducted one time at each of 10 stations in water year 2001, including 6 sites on the main stem of the Quinebaug River and 4 tributary sites (table 1). Two sets of three light-transmitting and three darkened bottles were used for the experiment. The bottles were 1-pint, glass, milk bottles (used primarily for USGS sediment collection) with plastic, snap-on caps. The light bottles were clear with no labels; conversely, the dark bottles were completely wrapped with black vinyl tape. 


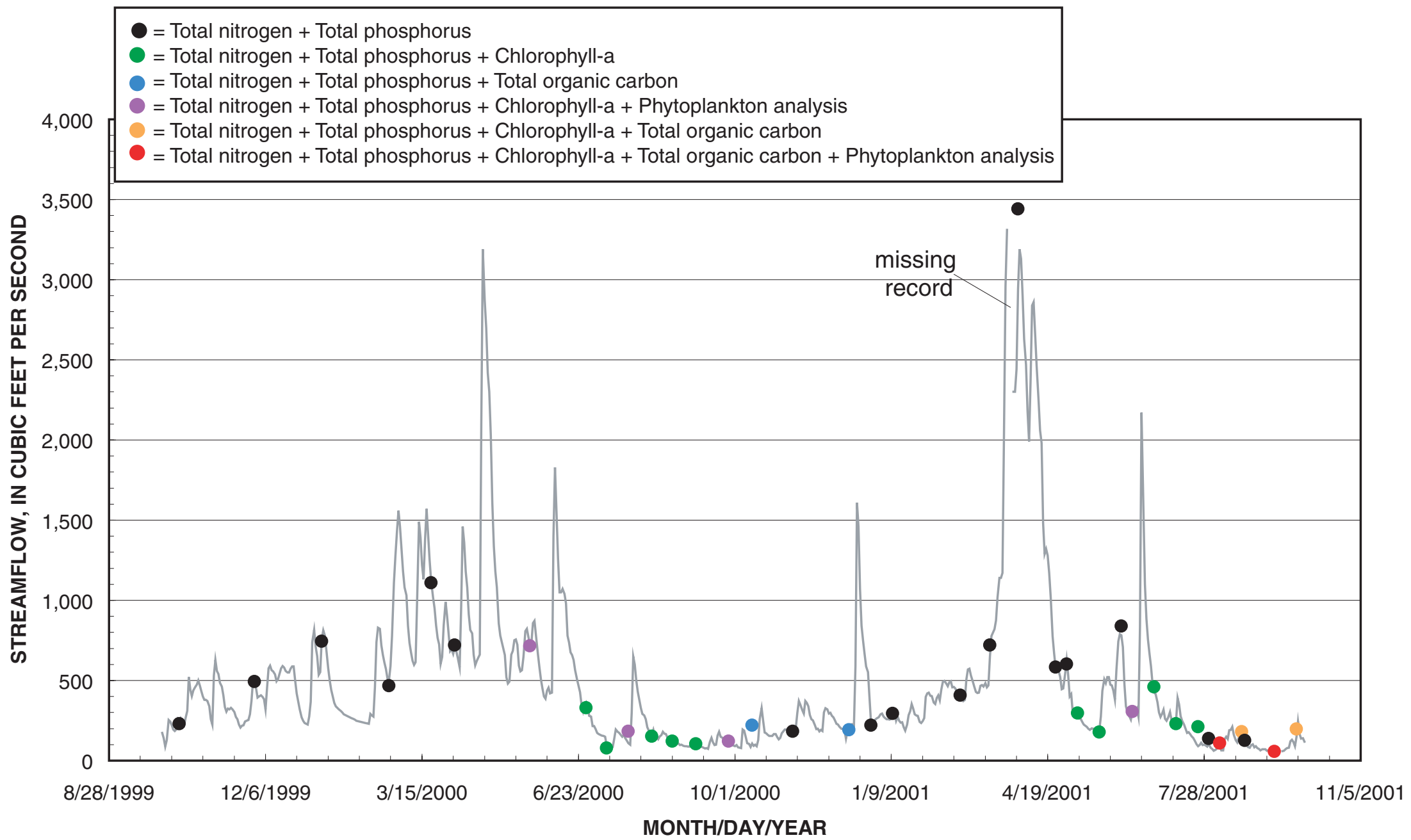

Figure 3. Streamflow at U.S. Geological Survey station 01125500, Quinebaug River at Putnam, Connecticut, indicating dates and flow conditions when water samples were collected, October 1999 through September 2001. [Dots represent instantaneous streamflow at time of sample collection.] 
The light- and dark-bottle experiments were conducted during the photoperiod (sunlight part of the day) in the euphotic zone (part of the aquatic environment with sufficient light for photosynthesis) of the Quinebaug River and its tributaries. The bottles were filled with unfiltered river water, sealed, and placed at a location within the euphotic zone on the riverbed for several hours. The dissolved oxygen in the river was measured and recorded initially when the bottles were filled. The euphotic zone was measured at several sites and was determined to extend to the river bottom during low- flow periods when the light- and dark-bottle productivity measurements were made. After a measured time interval of approximately 1 to 2 hours, the bottles were retrieved from the river, and a dissolved oxygen measurement was taken using a dissolved oxygen meter immediately upon opening each bottle. The measured values for each set of three light and three dark bottles for each site were averaged for one light-bottle value and one dark-bottle value.

\section{Nutrient Enrichment in the Quinebaug River Basin}

Water-quality samples collected during water years 2000 and 2001 substantiate the consistent and pervasive occurrence of elevated concentrations of total nitrogen and total phosphorus in wastewater-receiving parts of the Quinebaug River Basin. Runoff from agricultural lands also caused elevated nutrient concentrations in some parts of the basin. The following sections describe the extent of nutrient enrichment observed during this study in various parts of the Quinebaug Basin.

\section{Total Nitrogen}

Elevated concentrations of total nitrogen were measured throughout the Quinebaug River Basin in water years 2000 and 2001. Median total nitrogen concentrations in water samples from 9 of the 12 stations sampled for this study (fig. 4) equaled or exceeded the USEPA's proposed regional total nitrogen ambient water quality criterion of $0.71 \mathrm{mg} / \mathrm{L}$ (U.S. Environmental Protection Agency, 2000a). The maximum total nitrogen concentrations measured at the same nine stations during this study ranged from 1.2 to $4.8 \mathrm{mg} / \mathrm{L}$. The nine stations with elevated total nitrogen concentrations included all seven Quinebaug River mainstem stations and stations on two tributaries, the French River and Little River (fig. 4). The largest median total nitrogen concentration $(1.5 \mathrm{mg} / \mathrm{L})$ and the highest total nitrogen concentration $(4.8 \mathrm{mg} / \mathrm{L})$ in the basin observed during this study were in water samples from the French River near North Grosvenordale, Connecticut (USGS station 01125100). Several municipal wastewater-treatment plants discharge nutrient-enriched wastewater to the Quinebaug River and the French River upstream from the locations sampled for this study. Total nitrogen concentrations in the effluent samples collected at four of these wastewater-treatment plants during the summer of 2001 ranged from 1.5 to $25 \mathrm{mg} / \mathrm{L}$, and median total nitrogen concentration for each plant were 4.3, 9.2, 11.5 and $13.5 \mathrm{mg} / \mathrm{L}$. The Little River at Putnam, Connecticut (USGS station 01125499) does not receive wastewater discharges but this drainage basin contains substantially more agricultural land (24 percent) than other tributary streams or reaches of the Quinebaug River. The three tributary streams with the smallest total nitrogen concentrations-the Fivemile, Moosup, and Pachaug Rivers-do not receive wastewater discharges upstream from the sampled locations and contain less than 10 percent agricultural land.

Nutrient concentrations vary with variations in streamflow, as do most water-quality constituents. The nature of the relation between concentration and streamflow can provide an indication of the types of nutrient inputs upstream (Mueller and others, 1995). If the principal source of nitrogen is atmospheric fallout and leaching of forested and undeveloped areas, generally low concentrations persist over a broad range of streamflow conditions because no substantial dilution takes place. With a point source of nitrogen such as a wastewater-treatment plant, however, the effluent nitrogen concentration is added to the stream at a relatively stable rate on a day-to-day basis and instream concentrations increase as streamflow declines. Conversely, concentration decreases sharply as the volume of streamflow rises and dilution takes place. This pattern can be seen in a plot of total nitrogen and streamflow (fig. 5) for the French River near North Grosvenordale, Connecticut (USGS station 01125100). The total nitrogen concentrations decline exponentially as streamflow increases at this station, which receives effluent discharged from a municipal wastewater-treatment plant several miles upstream.

\section{Total Phosphorus}

The distribution of stations with elevated total phosphorus concentrations in the Quinebaug River Basin during water years 2000 and 2001(fig. 6) is similar to total nitrogen. Median total phosphorus concentrations equaled or exceeded the USEPA's proposed regional total phosphorus ambient water-quality criterion of $0.031 \mathrm{mg} / \mathrm{L}$ (U.S. Environmental Protection Agency, 2000a) in water samples from the same nine stations that showed elevated total nitrogen concentrations (fig. 4). The maximum total phosphorus concentrations observed at these nine stations during the study ranged from 0.07 to $0.18 \mathrm{mg} / \mathrm{L}$. Whereas the highest total nitrogen concentrations were measured in the French River near North Grosvenordale, Connecticut (USGS station 01125100), the largest median $(0.065 \mathrm{mg} / \mathrm{L})$ and maximum $(0.181 \mathrm{mg} / \mathrm{L})$ total phosphorus levels were measured at the Quinebaug River at Cotton Bridge Road near Pomfret Landing, Connecticut (USGS station 01125520). 


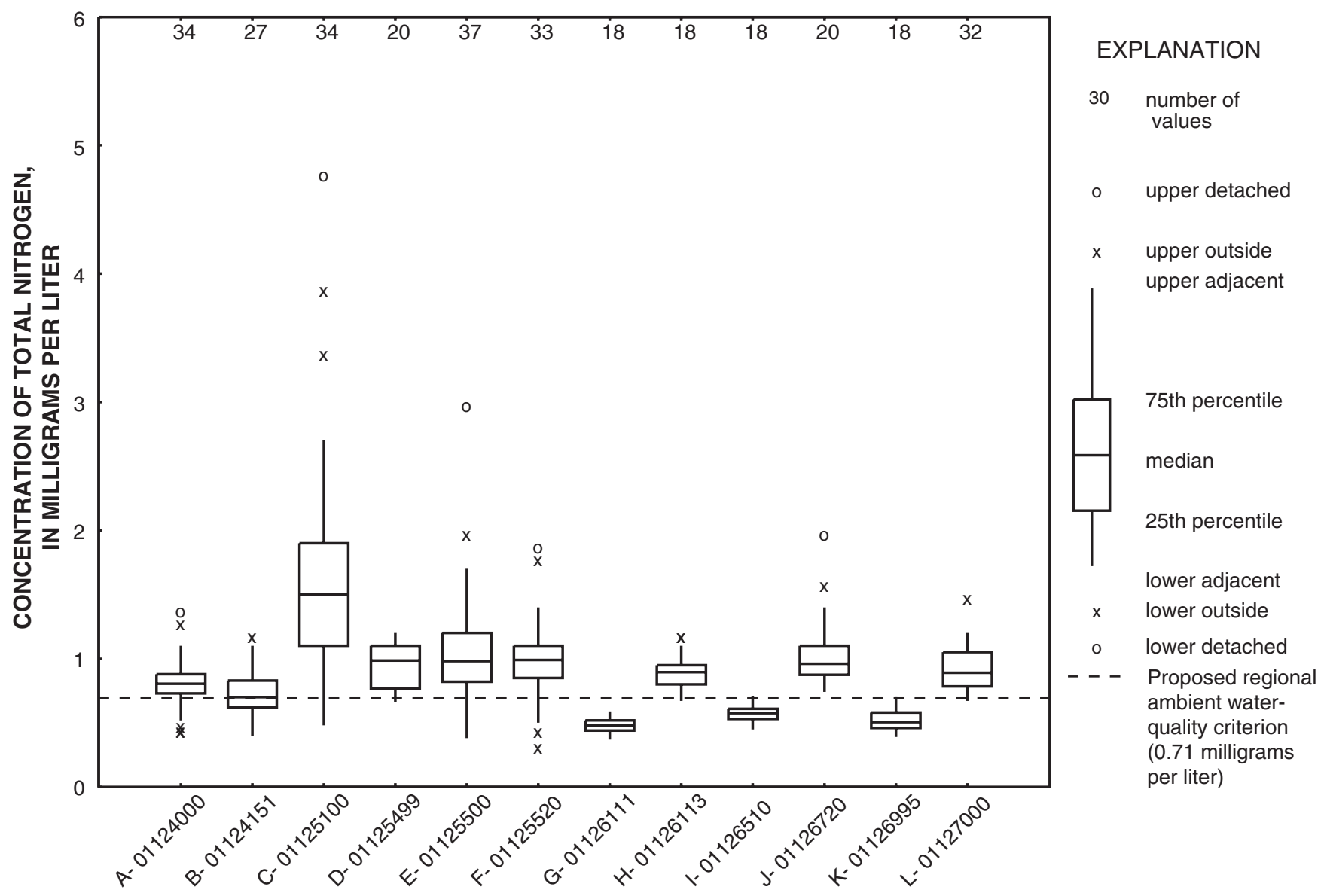

Figure 4. Concentration of total nitrogen at water-quality stations in the Quinebaug River Basin, October 1999 through September 2001.

A- Quinebaug R. at Quinebaug

B- Quinebaug R. at West Thompson

C- French R. near N. Grosvenordale

D- Little R. at Putnam

E- Quinebaug R. at Putnam

F- Quinebaug R. near Pomfret Landing

G- Fivemile R. at Danielson

H- Quinebaug R. at Danielson

I- Moosup R. at Plainfield

J- Quinebaug R. near Packer

K- Pachaug R. at Jewett City

L- Quinebaug R. at Jewett City

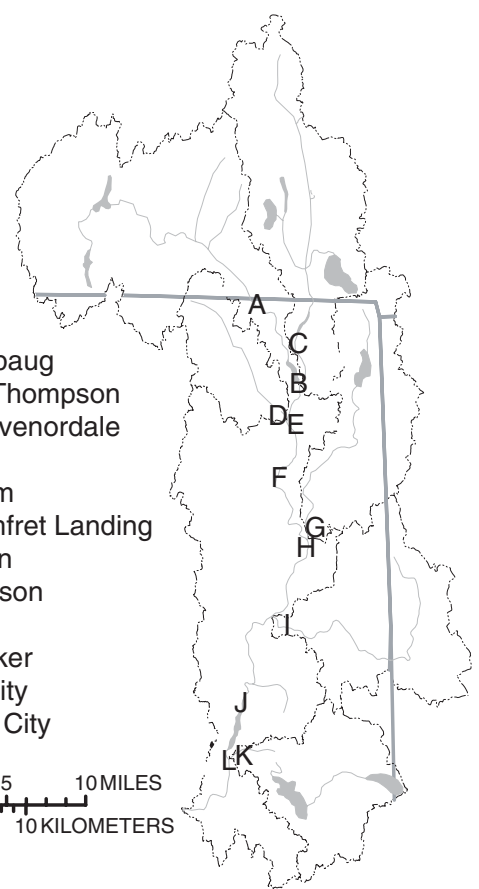

Lettered stations on this map refer to stations in boxplots above (fig. 4) and right (fig. 6). 
Figure 5. Relation between concentration of total nitrogen and streamflow for dates sampled during water years 2000 and 2001 at U.S. Geological Survey station 01125100, French River near North Grosvenordale, Connecticut.

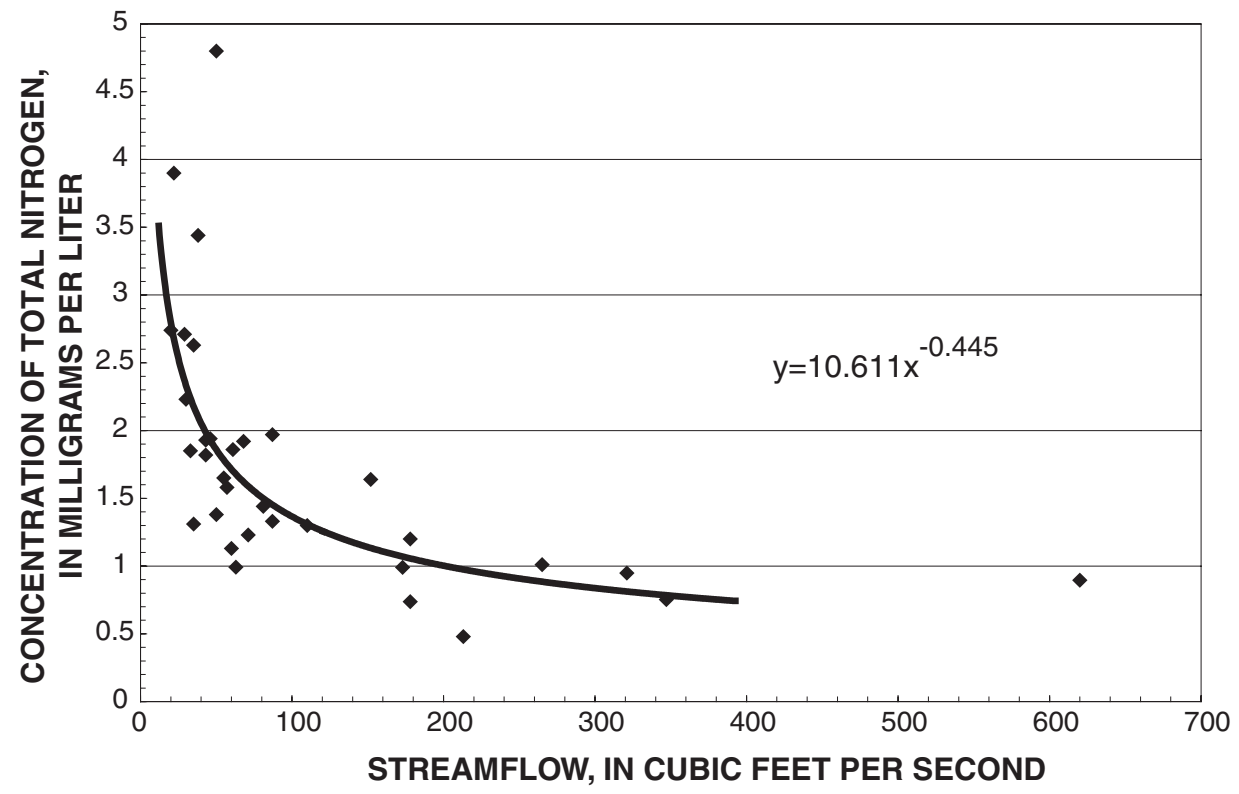

Figure 6. Concentrations of total phosphorus at water-quality stations in the Quinebaug River Basin, October 1999 through September 2001. 
Overall, 78 percent of all total phosphorus samples in the Quinebaug River Basin collected during the study equaled or exceeded the 0.031-mg/L proposed regional ambient waterquality criterion. As with total nitrogen, the geographic distribution of the water-quality stations with elevated total phosphorus concentrations reflects the distribution of point and nonpoint sources. The cumulative distribution curve of total phosphorus concentrations for the three tributary streams without wastewater or substantial agricultural phosphorus sources - the Fivemile, Moosup and Pachaug Rivers-plots significantly ( $\mathrm{p}<0.0001$ for a Kruskal-Wallis rank sum test) to the left of other Quinebaug River Basin stations (fig. 7). Collectively, about 85 percent of the total phosphorus concentrations in water samples from these three stations were less than 0.031 $\mathrm{mg} / \mathrm{L}$, and none of the samples from these stations had concentrations exceeding $0.1 \mathrm{mg} / \mathrm{L}$. Nonpoint sources of phosphorus in the Little River Basin resulted in fewer samples that would meet the proposed regional ambient water-quality criterion of $0.031 \mathrm{mg} / \mathrm{L}$; only about 30 percent of the samples from USGS station 01125499 had total phosphorus concentrations less than $0.031 \mathrm{mg} / \mathrm{L}$ (fig. 7). In water samples from stations on the mainstem of the Quinebaug River and the French River near North Grosvenordale, total phosphorus concentrations seldom were less than $0.031 \mathrm{mg} / \mathrm{L}$; fewer than 10 percent of the samples collected during this study at the French River and mainstem Quinebaug River stations would meet the proposed criterion. Although a variety of point and nonpoint phosphorus sources may contribute to the elevated total phosphorus concentrations at these stations, municipal wastewater-treatment plants are the most probable sources of total phosphorus concentrations that exceeded $0.1 \mathrm{mg} / \mathrm{L}$ in nearly 10 percent of the samples. Total phosphorus concentrations measured in effluent samples from four municipal wastewater-treatment plants that discharge to the Quinebaug River ranged from 0.242 to $4.03 \mathrm{mg} / \mathrm{L}$; the median effluent total phosphorus concentrations from the individual wastewater-treatment plants were $0.55,1.97,3.0$ and $3.34 \mathrm{mg} / \mathrm{L}$.

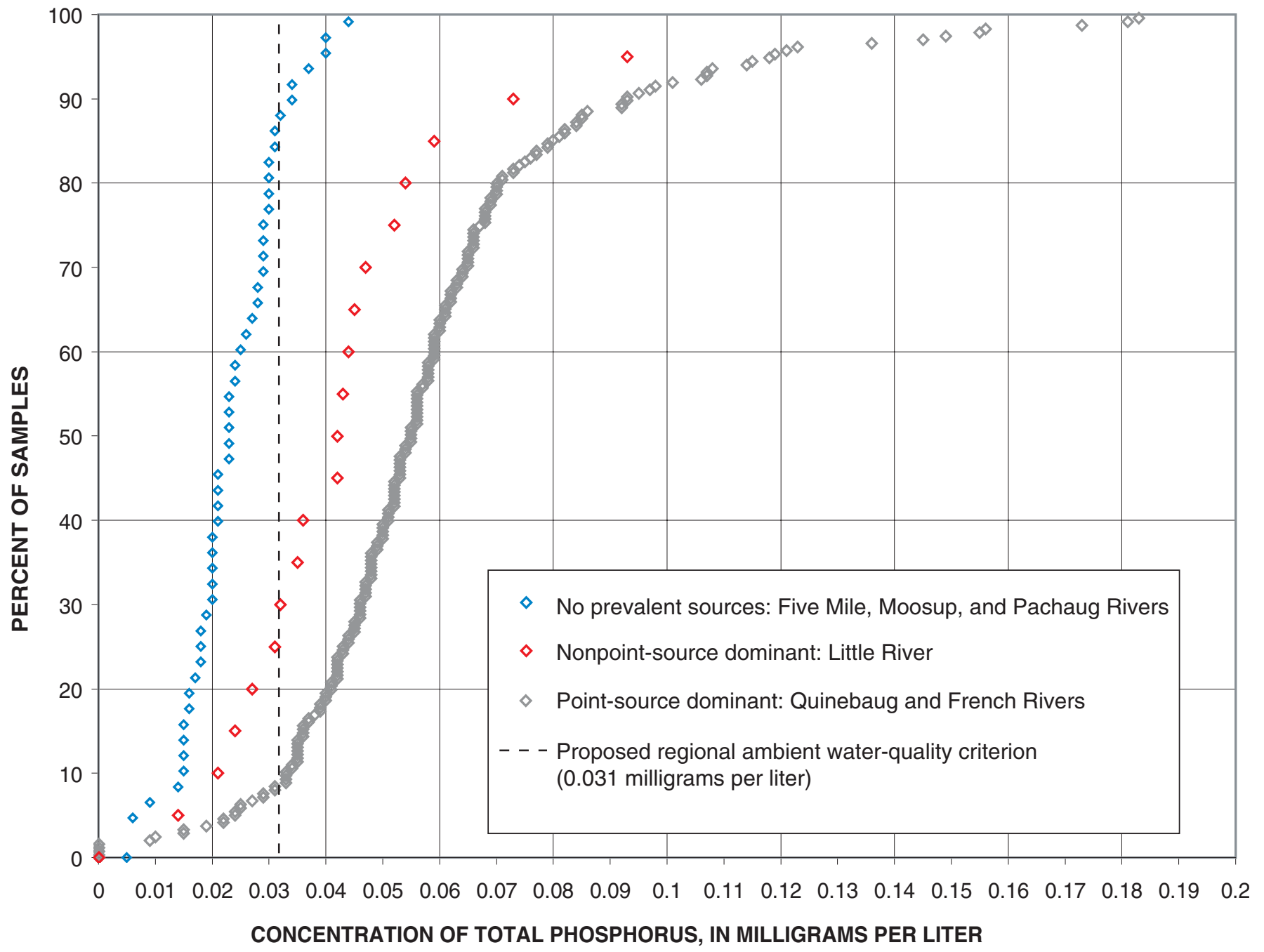

Figure 7. Cumulative distribution of total phosphorus concentrations in water samples collected during water years 2000 and 2001 from stations in the Quinebaug River Basin in relation to probable phosphorus sources. 


\section{Correlation Between Total Nitrogen and Total Phosphorus}

Generally, the correlation is relatively poor between total nitrogen and total phosphorus concentrations (fig. 8) in the Quinebaug River Basin ( $r=0.52)$; this reflects the differences in their sources as well as their transport mechanisms. For the tributary streams with no prevalent nutrient sources, total nitrogen is relatively constant at about $0.5 \mathrm{mg} / \mathrm{L}$, whereas total phosphorus ranges from less than 0.01 to $0.05 \mathrm{mg} / \mathrm{L}$ (fig. 8). For the Little River, which is affected by agricultural nonpoint sources, total nitrogen concentrations vary only a little above or below the $1.0-\mathrm{mg} / \mathrm{L}$ level, whereas total phosphorus concentrations extend nearly an order of magnitude from near zero to almost $0.1 \mathrm{mg} / \mathrm{L}$ (fig. 8). It is only in the reaches of the Quinebaug and French Rivers affected by wastewater-treatment plant point sources that total nitrogen concentrations increase proportionally with total phosphorus concentrations in some samples. A number of factors probably account for the weak total nitrogen: total phosphorus correlation; these include the composition of fertilizers used on agricultural and residential land, with formulations that often contain 10 to 50 times more nitrogen than phosphorus; the seasonal removal of phosphorus from some municipal wastewater effluents; differential aquatic attenuation processes; and the fact that nitrogen species are transported mostly in a dissolved state whereas phosphorus species tend to adsorb to sediment particles.

\section{Effect of Nutrient Enrichment on Phytoplankton Algal Growth}

Low streamflow velocities, warm temperatures, and long hours of daylight all act together to promote algal growth in areas where concentrations of nutrients are elevated during summer and early fall. These conditions favor phytoplankton rather than periphyton dominance. Summer and fall algal blooms that produce turbid, deep-green discolored water (see fig. 2) have been observed at a number of locations on slowmoving and impounded reaches of the Quinebaug, French, and Little Rivers for more than 20 years (Connecticut Department of Environmental Protection, 1978; Kulp, 1991; Healy and Kulp, 1995). Although a variety of phytoplankton have been identified in recent efforts to characterize the algal community (Connecticut Department of Environmental Protection, 1998b), blue-green algae were the predominant contributors to the phytoplankton biomass during periods of nuisance algal growth observed in the Quinebaug River Basin.

Algal biomass is the amount of algae in a water body at a given time. Two methods were used during this study to measure seston algal biomass: microscopic counts of phytoplankton cells and determinations of chlorophyll-a concentrations.

\section{Phytoplankton Density}

Phytoplankton samples were collected three to four times during the summer of 2000 and three times during the summer of 2001 at 12 stations (table 2) for microscopic examination. The results of algal identification and enumeration are reported by taxa in appendix 5 , and the observed phytoplankton densities are summarized in table 2 . Measured phytoplankton density ranged from 0 algal $\mathrm{c} / \mathrm{mL}$ (cells per milliliter) in samples from four stations (at least once during the study), including two on the main stem of the Quinebaug River plus two tributaries, to an observed maximum of 85,000 algal $\mathrm{c} / \mathrm{mL}$ at the Quinebaug River near Packer, Connecticut in September 2001. Phytoplankton densities exceeding 10,000 algal $\mathrm{c} / \mathrm{mL}$ were observed in 16 percent ( 12 of the 77 samples) of the phytoplankton samples collected over the two summers. Eight of the 10 highest phytoplankton densities were measured during August and September 2001 at stations on impounded or slowmoving reaches of the Quinebaug River; the stations with high phytoplankton density were among the nine stations with median total phosphorus concentrations greater than $0.031 \mathrm{mg} /$ L (fig. 6). Generally, algal densities were lower, showed a less consistent pattern of increasing over the summer, and peaked earlier during the summer of 2000 than in 2001.

The different patterns of algal growth and the generally lower densities observed during the summer of 2000 compared to the summer of 2001 may relate to differences in precipitation and the consequence of that precipitation-higher sustained streamflow in 2000 than 2001 (fig.9). Annual precipitation at the National Oceanic and Atmospheric Administration (NOAA) climatological station at Worcester, Mass. for the year 2000 (44.14 in.) was slightly below average (44.75 in.), but the 32.32 in. recorded for the year 2001 was substantially (15.43 in.) below average. Although annual precipitation totals were below average in both 2000 and 2001, precipitation recorded during the summer months of both years was greater than normal. Streamflow in the summer of 2000 was consistently higher than in the summer of 2001, particularly for May and June, and higher even than median streamflow for the period of record (fig. 9). Comparatively, the average mean daily streamflow of the Quinebaug River at Putnam, Conn. (fig. 10) for the 153 days from May 1 through September 30, 2000 was $379 \mathrm{ft}^{3} / \mathrm{s}$; whereas average mean daily streamflow was $255 \mathrm{ft}^{3} / \mathrm{s}$ for the same period in 2001. Additionally, only two or three brief periods of relatively elevated streamflow occurred during the summer of 2001, and these periods were both of short duration and before mid-July (fig. 10). Cool, wet periods with elevated streamflow were more pervasive during the summer of 2000, including a 2week period in late July and early August 2000 (fig. 10) that is likely to have flushed the standing crop of algae from impoundments; the elevated streamflow likely diluted nutrient concentrations and carried more turbid waters that would limit solar insolation and subsequently hinder algal growth. 


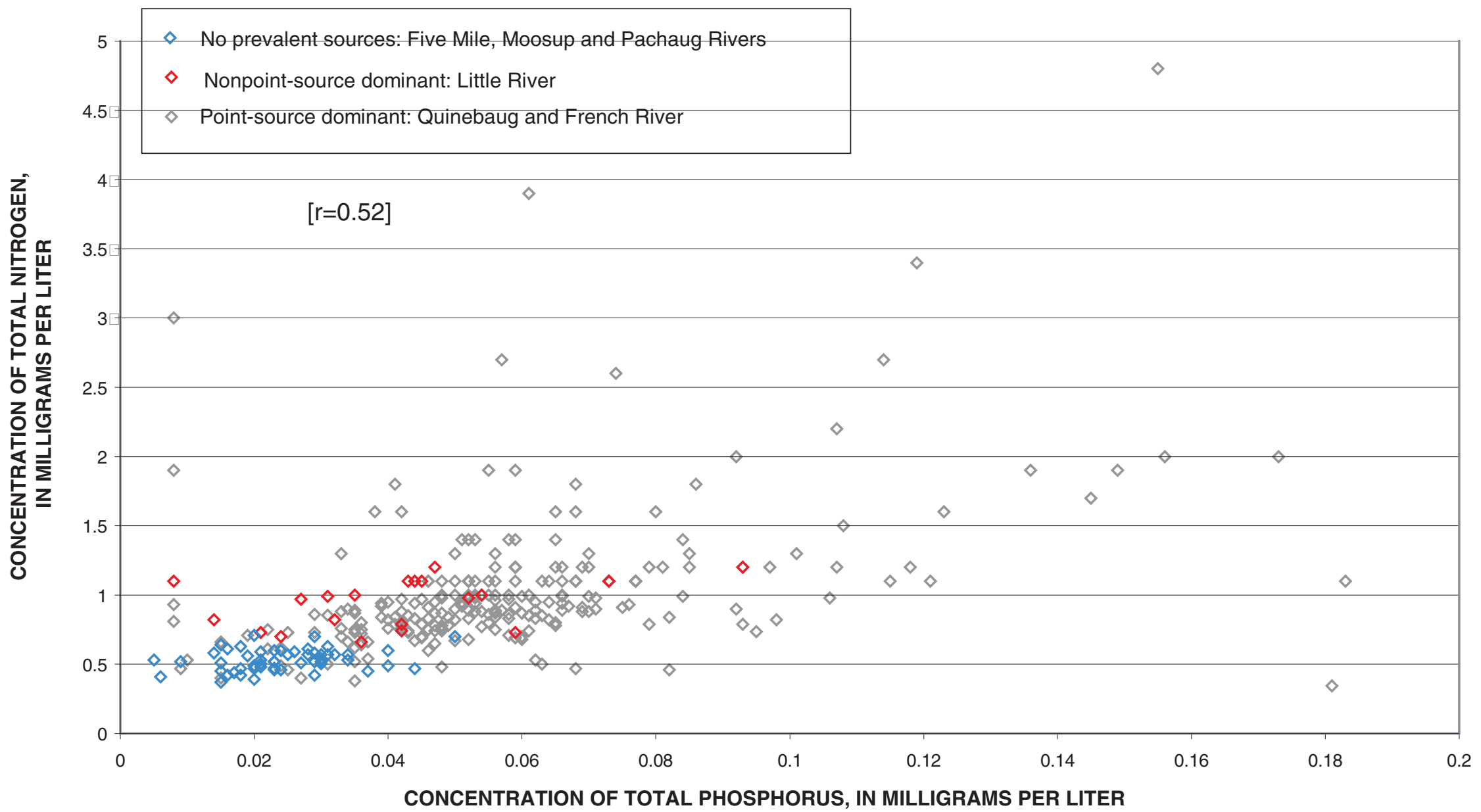

Figure 8. Concentration of total nitrogen plotted against concentration of total phosphorus in water samples collected during water years 2000 and 2001 from stations in the Quinebaug River Basin, Connecticut, in relation to probable nutrient sources. 
Table 2. Phytoplankton density at sampling locations in the Quinebaug River Basin, Connecticut, water years 2000 and 2001.

[Phytoplankton enumeration performed by Connecticut Department of Environmental Protection (DEP) using Sedgwick-Rafter cell counts as described by American Public Health Administration, 1992; values are rounded; c/mL, cells per milliliter; --, not sampled

\begin{tabular}{|c|c|c|c|c|c|c|c|c|}
\hline \multicolumn{2}{|r|}{ U.S. Geological Survey station } & \multicolumn{7}{|c|}{ Phytoplankton density (algal c/mL) on sample-collection dates } \\
\hline Number & Name & $\begin{array}{c}\text { May } \\
22-25, \\
2000\end{array}$ & $\begin{array}{c}\text { July } \\
24-27 \text {, } \\
2000\end{array}$ & $\begin{array}{c}\text { August } \\
23-25, \\
2000\end{array}$ & $\begin{array}{c}\text { Sept. } \\
26-29 \\
2000\end{array}$ & $\begin{array}{c}\text { June } \\
11-15, \\
2001\end{array}$ & $\begin{array}{c}\text { August } \\
6-10 \\
2001\end{array}$ & $\begin{array}{c}\text { Sept. } \\
10-14, \\
2001\end{array}$ \\
\hline 01124000 & $\begin{array}{l}\text { Quinebaug River at Quinebaug, } \\
\text { Conn. }\end{array}$ & 140 & 70 & -- & 0 & 280 & 70 & 140 \\
\hline 01124151 & $\begin{array}{l}\text { Quinebaug River at West } \\
\text { Thompson, Conn. }\end{array}$ & 910 & 4,400 & -- & 4,000 & 1,600 & 18,000 & 22,000 \\
\hline 01125499 & Little River at Putnam, Conn. & 630 & 62,000 & -- & 1,500 & 2,500 & 840 & 560 \\
\hline 01125500 & Quinebaug River at Putnam, Conn. & 1,200 & 4,000 & -- & 3,800 & 1,500 & 1,900 & 18,000 \\
\hline 01125520 & $\begin{array}{l}\text { Quinebaug River at Cotton Bridge } \\
\text { Road near Pomfret Landing, Conn. }\end{array}$ & 0 & 12,000 & 560 & 1,200 & 1,600 & 2,200 & 25,000 \\
\hline 01126720 & Quinebaug River near Packer, Conn. & 490 & 910 & 210 & 980 & 1,500 & 15,000 & 85,000 \\
\hline 01126995 & Pachaug River at Jewett City, Conn. & 280 & 4,000 & 210 & 140 & 2,000 & 9,800 & 2,300 \\
\hline 01127000 & $\begin{array}{l}\text { Quinebaug River at Jewett City, } \\
\text { Conn. }\end{array}$ & 980 & 4,900 & 1,800 & 1,800 & 3,400 & 21,000 & 59,000 \\
\hline
\end{tabular}

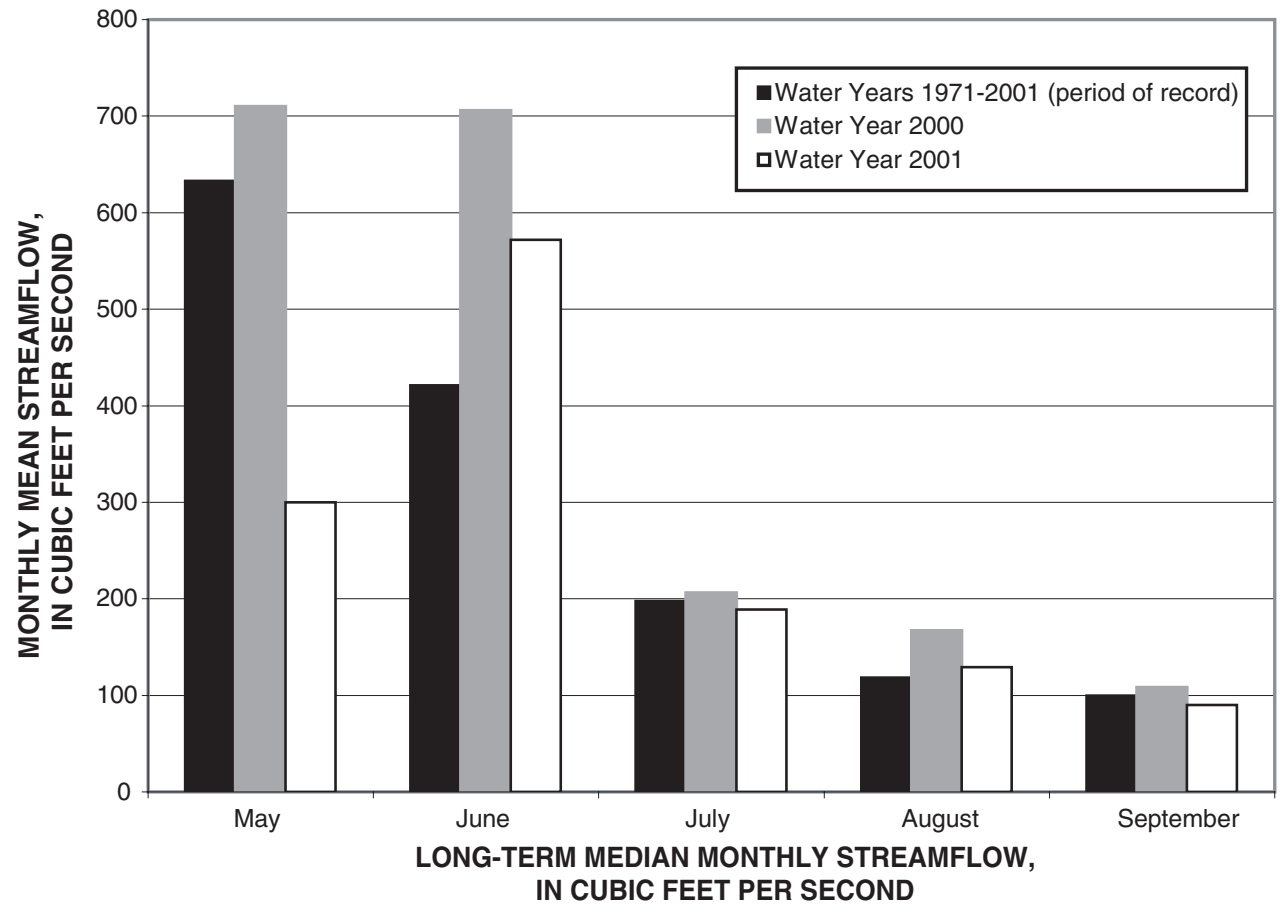

Figure 9. Long-term median monthly streamflow plotted against monthly mean streamflow during the growing seasons of water years 2000 and 2001 for U.S. Geological Survey station 01125500, Quinebaug River at Putnam, Connecticut. 


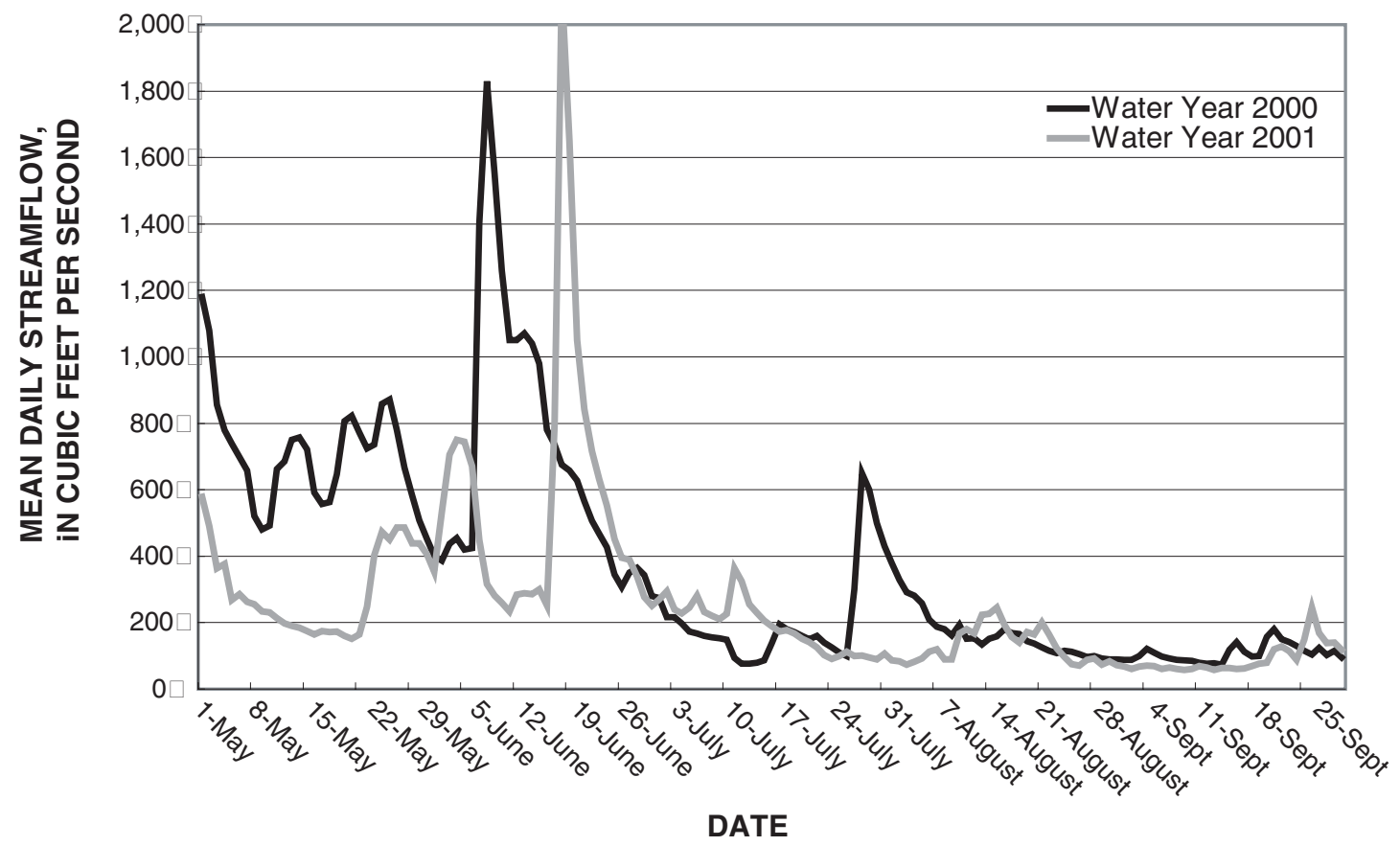

Figure 10. Mean daily streamflow during the growing seasons of water years 2000 and 2001 for U.S. Geological Survey station 01125500, Quinebaug River at Putnam, Connecticut.

\section{Algal Community Succession}

Algae have life cycles that span hours to days and integrate water quality over a relatively short period of time. As physical, chemical, and biological conditions in a stream change over time, some species of algae compete better for available resources or can tolerate the changing conditions. Consequently, as time passes during the growing season, a succession of various types of algae is typical (Wetzel, 1983). Generally, the succession may begin with diatoms as the dominant or only species present from winter into early spring. Then in late spring, with warmer water, more daylight, and potentially greater nutrient availability, green algae appear, and ultimately, in eutrophic streams, cyanobacteria (blue-green algae) take precedence. Although this pattern of algal succession probably occurs to some degree every summer, perturbations in the physical environment (storms, extended cool and wet periods, and regulation in streamflow) can disrupt its timing and sequence. Other factors, such as the establishment of a herbivore zooplankton population, or events that limit nutrient availability (lack of agricultural runoff and potential disruptions or elimination of nutrient-bearing point-source discharges), could preclude the establishment and (or) full development of successive algal communities.

A comparison of the algal community and abundance data from the station on the Quinebaug River at West Thompson, Connecticut (USGS station 01124151) demonstrates the differences observed in algal populations in the Quinebaug River between the summers of 2000 and 2001 (fig. 11). In May 2000, total algal abundance at West Thompson was less than 1,000 algal $\mathrm{c} / \mathrm{mL}$ and consisted entirely of diatoms (Bacillariophyceae). This site was not sampled in June 2000 for phytoplankton analysis, but in July, even after wet weather in spring and early summer, the exclusive diatom community had essentially been replaced by a more abundant community of green algae (Chlorophyceae) and blue-green algae/cyanobacteria (Cyanophyceae) with a small number of dinoflagellates (Dinophyceae) present. In late September 2000, diatom populations were reestablished, replacing the green algae, and the cyanobacteria were in decline. For the most part, truly nuisance algal biomass concentrations causing deep green coloration or floating algal mats were not observed at West Thompson or most other stations in the basin in 2000. During the summer of 2001, however, warm dry weather and lower streamflows, in conjunction with high nutrient concentrations, produced algal blooms with stream discoloration similar to events previously observed at this site. In June 2001, cyanobacteria already dominated the seston algal community, and, with continued favorable growing conditions, populations of blue-green algae expanded exponentially to more than 13,000 algal $\mathrm{c} / \mathrm{mL}$ in August and nearly 19,000 algal c/mL in September (fig. 11, appendix 5). Green algae, as well as diatom populations all expanded in August 2001 at this site and subsequently declined in September. Similar patterns of algal succession were observed at most of the main stem stations during 2001, whereas the tributaries, in particular the Fivemile and Moosup Rivers, saw little or no succession to green and blue-green algae. 

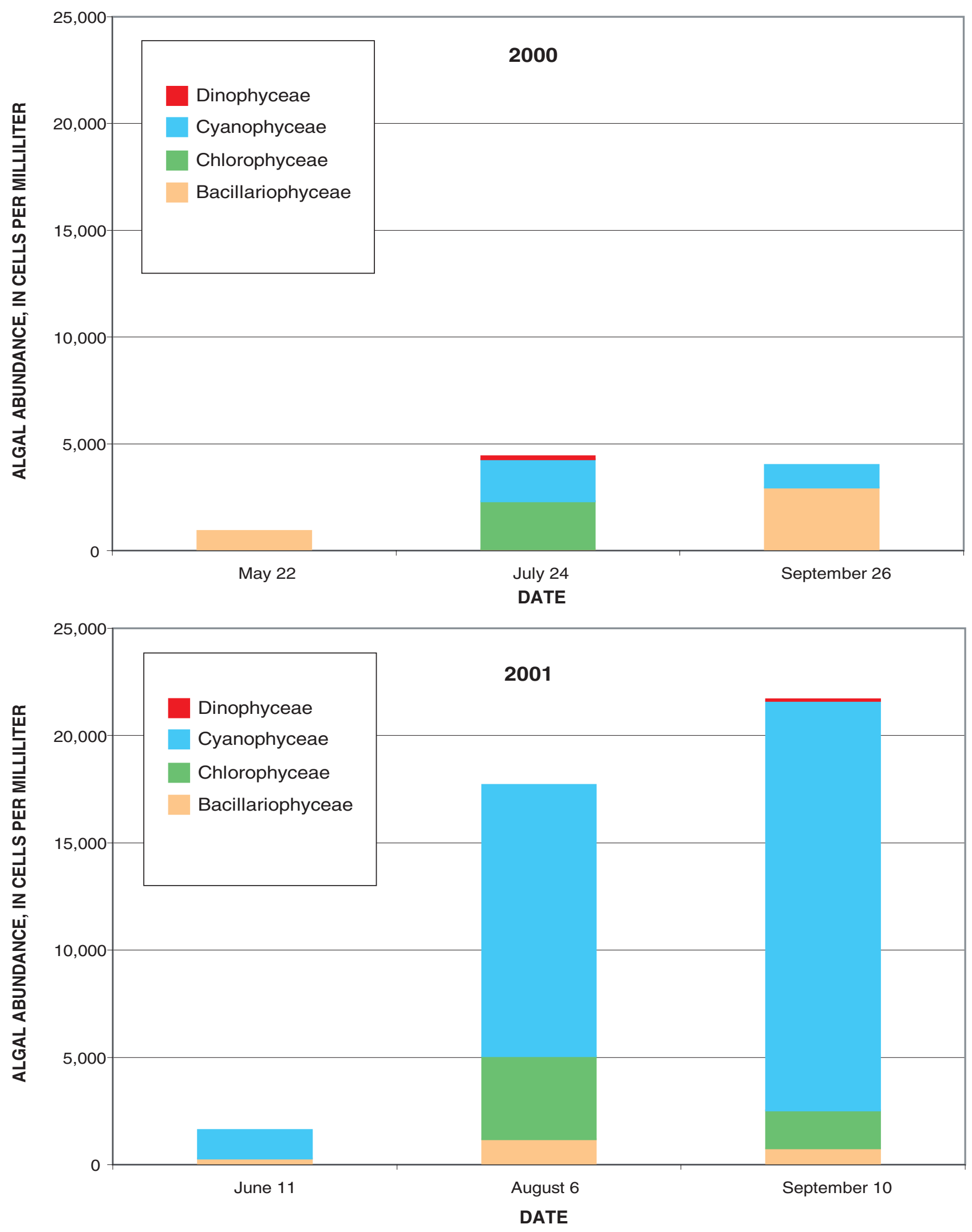

Figure 11. Seston algal communities in the Quinebaug River at West Thompson, Connecticut, during the summers of 2000 and 2001. 


\section{Chlorophyll-a}

Chlorophyll-a is a green pigment that is common to all phytoplankton and is the principal photosynthetic pigment responsible for a plant's ability to convert sunlight into the chemical energy needed to fix carbon dioxide into cell biomass. Chlorophyll-a concentrations are widely used to estimate phytoplankton biomass because a comprehensive microscopic enumeration of the dozens of species of algae that may be present in the water column is often tedious, time consuming, and may be prohibitively costly or impractical. Chlorophyll-a concentrations measured in samples from the Quinebaug River Basin during water years 2000 and 2001 generally increased proportionally with algal abundance (fig. 12). Chlorophyll-a concentrations are low in clean, natural waters and, similarly, can be low in flowing surface-water bodies that are nutrientenriched, because even slow-moving streams may disperse phytoplankton before high algal biomass develops. Further, seston chlorophyll-a concentrations are limited in most deep, slow-moving rivers to approximately $10 \mu \mathrm{g} / \mathrm{L}$ (micrograms per liter) by light attenuation (U.S. Environmental Protection Agency, 2000b). Under conditions that promote the rapid and expansive growth of algal populations in shallow waters, however, chlorophyll-a concentrations can attain levels of 70 to $125 \mu \mathrm{g} / \mathrm{L}$ (U.S. Environmental Protection Agency, 2000b). The
USEPA's recommended regional ambient water-quality criterion for chlorophyll-a is $3.75 \mu \mathrm{g} / \mathrm{L}$ to protect aquatic resources (U.S. Environmental Protection Agency, 2000a) ${ }^{2}$.

Chlorophyll-a concentrations in water samples from the Quinebaug River Basin during this study ranged from 0.2 to $42 \mu \mathrm{g} / \mathrm{L}$. Concentrations were highest in samples from the wastewater-receiving parts of the system-the French and Quinebaug Rivers-and were lowest in samples from the unimpaired tributaries - the Fivemile, Moosup, and Pachaug Rivers (fig. 13). Nearly half (49 percent) of all chlorophyll-a concentrations exceeded the USEPA's 3.75- $\mu \mathrm{g} / \mathrm{L}$ recommended regional water-quality criterion, but chlorophyll-a (and consequently algal biomass) levels above the $3.75-\mu \mathrm{g} / \mathrm{L}$ threshold most often were present (62 percent) in samples from the French and Quinebaug Rivers. Of note, however, was that the distribution of chlorophyll-a concentrations in samples from the Little River at Putnam, Connecticut (USGS station 01125499) was clearly comparable to the wastewater-receiving main stem stations of the French and Quinebaug Rivers (fig. 13). Runoff of agricultural fertilizers and animal wastes into the $39-\mathrm{mi}^{2} \mathrm{Lit}-$ tle River drainage basin appears to affect algal responses in a manner comparable to those of wastewater discharges in the larger streams.

\footnotetext{
${ }^{2}$ The USEPA's chlorophyll-a recommended regional ambient water-quality criterion is based upon chlorophyll-a determinations using the spectrophotometric method (U.S. Environmental Protection Agency, 2000a, p. 14). Sorenson and others (1999, p. 23) have reported that chlorophyll-a concentrations determined by the NWQL using High Performance Liquid Chromatography (HPLC) were slightly less than half of those determined by the fluorometric method. Chlorophyll-a concentrations were determined for this study by the NWQL using HPLC and as such may be negatively biased with respect to chlorophyll-a concentration determined by USEPA methods.
}

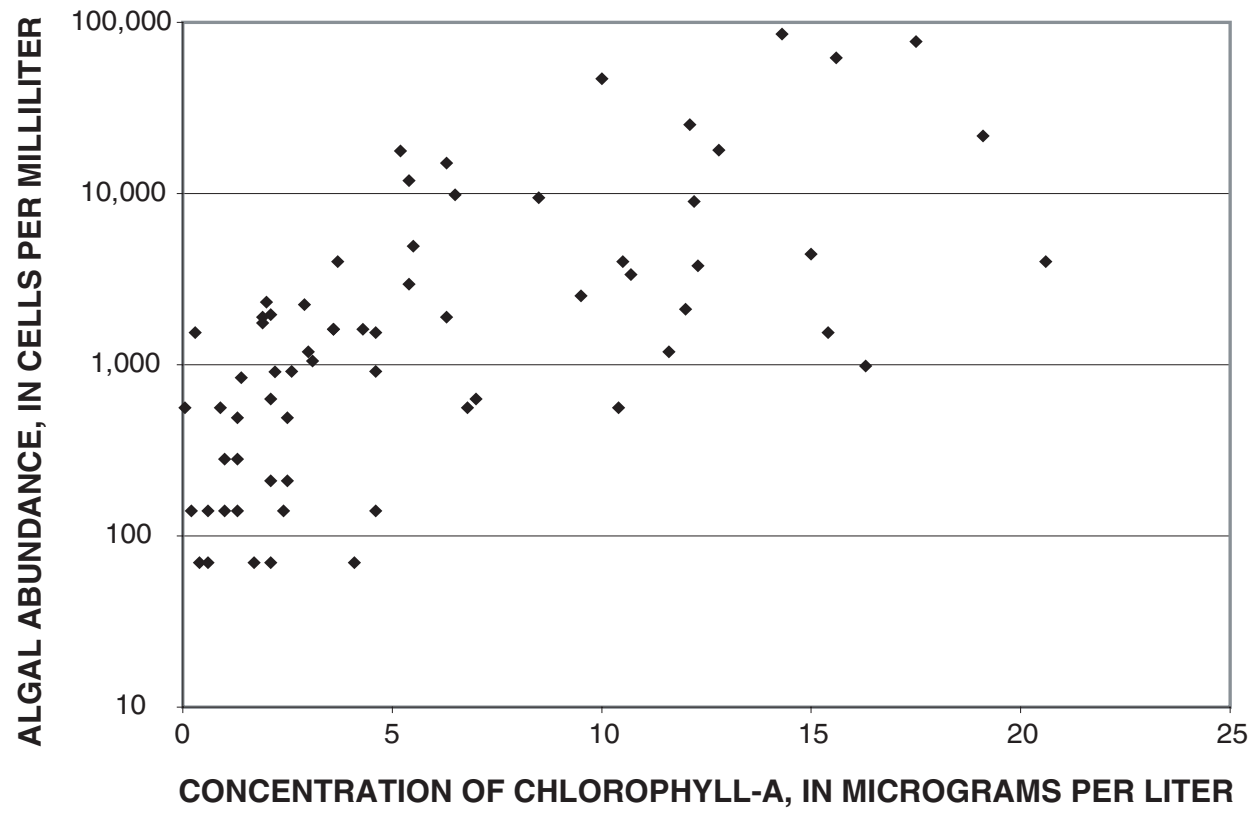

Figure 12. Relation of concentration of seston chlorophyll-a to phytoplankton algal abundance in the Quinebaug River Basin, Connecticut, October 1999 through September 2001. 


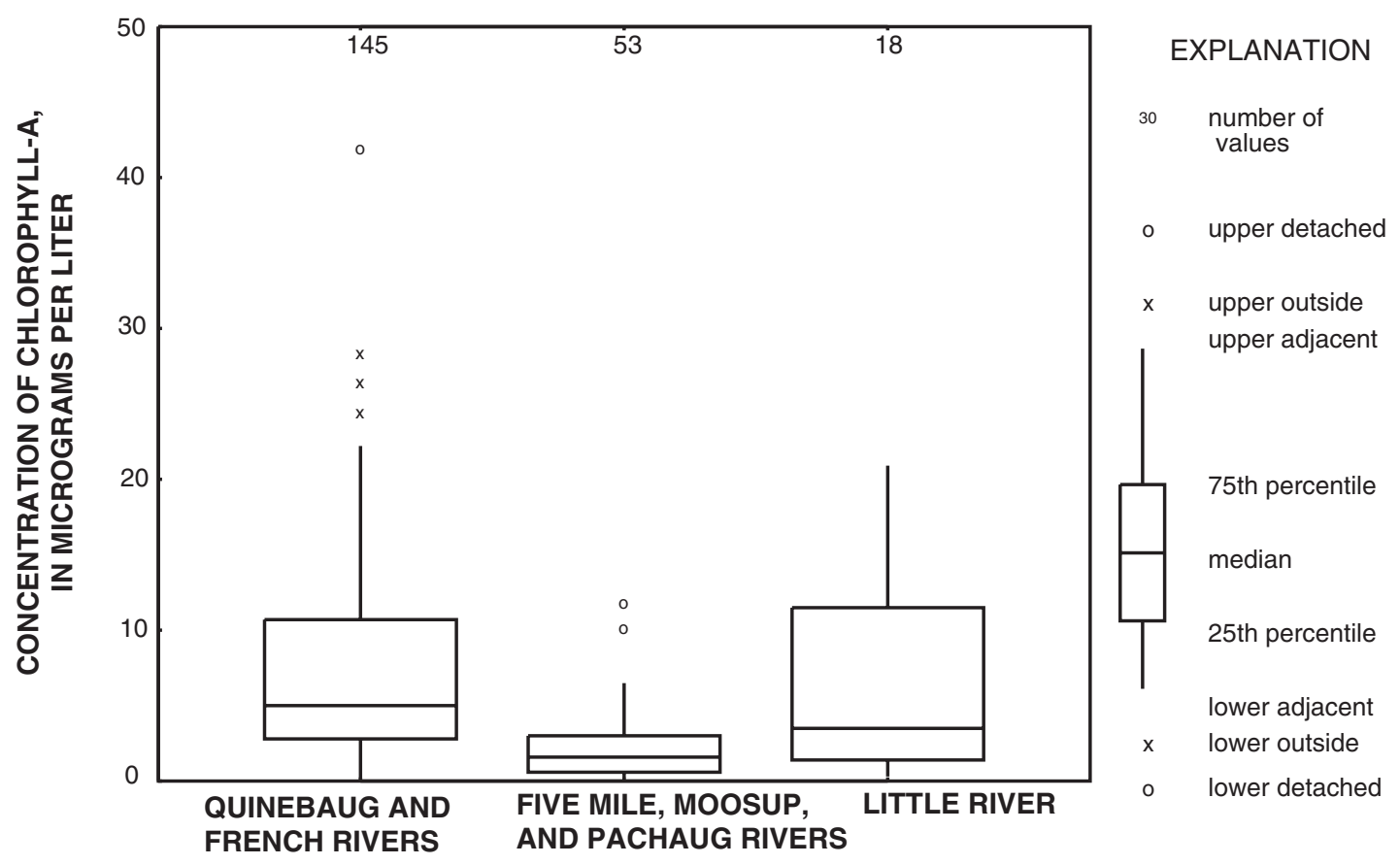

Figure 13. Concentrations of chlorophyll-a in the Quinebaug River and tributary streams, Connecticut, October 1999 through September 2001.

\section{Estimated Rates of Instream Metabolic Processes}

Temporal and spatial variations in rates of instream metabolic processes, primary productivity and respiration, were quantified and evaluated at locations in the Quinebaug River Basin using two methods: (1) interpolations from dissolved oxygen data from continuous monitors at four sites during 2000 and 2001 and (2) observed differences in dissolved oxygen concentrations in paired light- and dark-bottle measurements made during the summer of 2001.

\section{Rates Determined from Continuous Water-Quality Monitor Data}

Data from the continuous water-quality monitors can be used to estimate rates of primary productivity and respiration in streams (Sorenson and others, 1999; Peterson and others 2001). Both dissolved oxygen and $\mathrm{pH}$ may exhibit diel variation as a result of primary production and respiration of algal communities. Generally, dissolved oxygen and $\mathrm{pH}$ increase sharply during daylight hours as algae use energy from sunlight to take in nutrients and carbon dioxide and release oxygen. At night, photosynthesis ceases, and dissolved oxygen and $\mathrm{pH}$ decrease as aquatic plants and animals continue to respire. The rate of primary productivity and respiration can be calculated from the slope of the diel curve, which is a plot of the change in dissolved oxygen over time (Peterson and others, 2001). The process can be expressed as a rate of change in either a positive (increasing) or negative (decreasing) direction in grams of oxygen per cubic meter per hour $\left(\mathrm{g} \mathrm{O}_{2} / \mathrm{m}^{3} / \mathrm{hr}\right)$. The linear portion of the positive slope of the diel curve is taken as the maximum estimated rate of productivity and termed $\mathrm{P}_{\max }$; the linear portion of the negative slope of the diel curve is the maximum estimated rate of respiration or $\mathrm{R}_{\max }$ (fig. 14).

Rates of stream productivity and respiration were calculated for the four main stem sites with a continuous water-quality monitor (see table 1) for all days with complete or nearly complete dissolved oxygen data, and without large changes in streamflow that often disrupted the dissolved oxygen concentration plot. First, the recorded 15-minute continuous-monitor dissolved oxygen data for each site were used to generate diel curves (fig. 14). Then the linear periods of rapidly changing dissolved oxygen concentrations were determined. For example, the rapid rates of dissolved oxygen change between 9:00 a.m. and 3:00 p.m. and between 7:00 p.m. and midnight on July 21, 2001 at the Quinebaug River at Cotton Bridge Road near Pomfret Landing, Connecticut (USGS station 01125520) were linear. Productivity estimates were determined by calculating the slope of the dissolved oxygen (DO) concentrations between 9:00 a.m. and 3:00 p.m.:

$$
\begin{gathered}
\text { Stream Productivity }\left(\mathrm{P}_{\max }\right)=3: 00 \mathrm{p} . \mathrm{m} . \mathrm{DO}-9: 00 \text { a.m. DO/6 hours } \\
=(11.3 \mathrm{mg} / \mathrm{L}-7.5 \mathrm{mg} / \mathrm{L}) / 6 \text { hours } \\
\left.=0.63 \mathrm{mg} \mathrm{O}_{2} / \mathrm{L} / \mathrm{hr} \text { (which is equivalent to } 0.63 \mathrm{~g} \mathrm{O}_{2} / \mathrm{m}^{3} / \mathrm{hr}\right) .
\end{gathered}
$$

Similarly, respiration estimates were determined by calculating the DO slope between 7:00 p.m. and midnight:

Stream Respiration $\left(\mathrm{R}_{\max }\right)=-[$ 7:00 p.m. DO - Midnight DO $] / 5$ hours

$$
\begin{gathered}
=-[(10.6 \mathrm{mg} / \mathrm{L}-7.8 \mathrm{mg} / \mathrm{L}) / 5 \text { hours }] \\
=-0.56 \mathrm{~g} \mathrm{O}_{2} / \mathrm{m}^{3} / \mathrm{hr}
\end{gathered}
$$




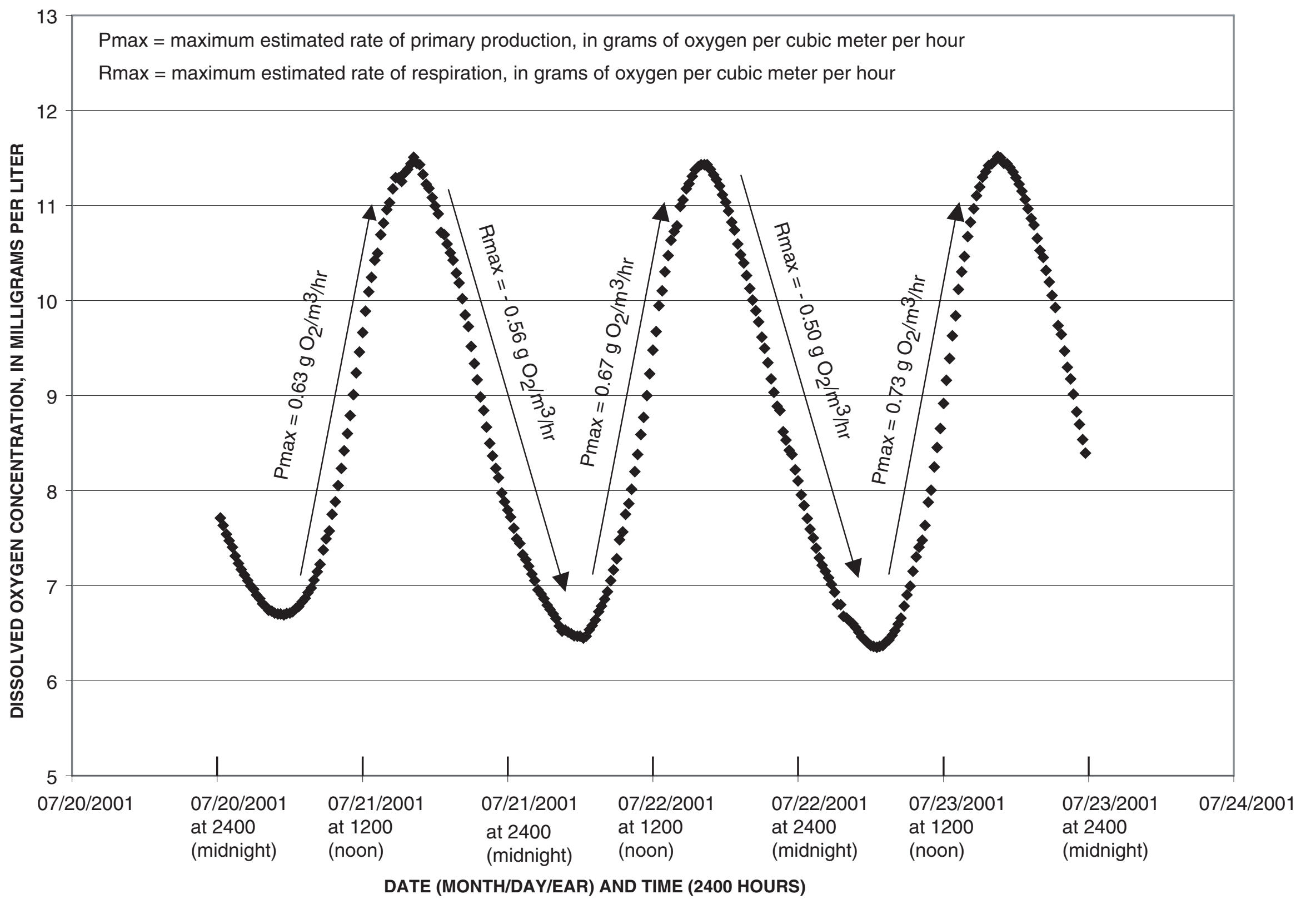

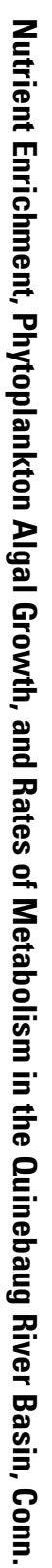

Figure 14. Determination of the maximum estimated rate of primary productivity and respiration from continuous monitor dissolved oxygen data at U.S. Geological Survey station 01125520, Quinebaug River at Cotton Bridge Road near Pomfret Landing, Connecticut. 
Similar curves were determined for each site and each date for which sufficient, undisturbed dissolved oxygen data were recorded to allow an estimate of stream metabolic rate to be computed; however, continuous-monitor-based estimates of $\mathrm{P}_{\max }$ and $\mathrm{R}_{\max }$ do not account for losses or gains due to oxygen diffusion that is a function of water temperature and barometric pressure (Odum, 1956) or accrual of surface and ground water (Britton and Greeson, 1989).

Primary productivity and respiration estimates based on the dissolved oxygen data (appendixes 1 to 4 ) from the continuous water-quality monitors represent seasonal trends in the duration of daylight, as well as short-term changes in flow conditions and various weather patterns throughout the growing season. Phytoplankton growth, as well as other aquatic plant growth, favors stagnant, shallow, nutrient-rich streams; thus for any given stream location, metabolic rates generally are inversely related to streamflow (fig. 15A). Consequently, estimated stream metabolic rates in the Quinebaug River often vary considerably from day to day, even for the same station (fig. 15B). Some areal and seasonal patterns are evident, however, that probably reflect differences in both anthropogenic and natural factors.

The Quinebaug River at Jewett City showed the highest daily maximum productivity rate $\left(1.72 \mathrm{~g} \mathrm{O}_{2} / \mathrm{m}^{3} / \mathrm{hr}\right)$ measured in the study as well as the highest median productivity and respi- ration rates for the four measured sites (table 3). This station is located on the Quinebaug River below the outflow from the Aspinook Pond impoundment, a eutrophic, largely stagnant reach of the lower part of the Quinebaug River. A hydroelectricpower plant taps the Quinebaug River at this location, and the regulation of streamflow with a daily pattern of water released from storage to pass through turbine generators causes rapid changes in dissolved oxygen concentrations (fig. 16). The continuous water-quality monitor data at this site show a pattern of generally sharp rises in dissolved oxygen as aerated water passing through the turbines reaches the monitor, then a decline as the hydroelectric release passes by and backwater formed behind the release reaches the monitor superimposed on the daily fluctuations. These perturbations in dissolved oxygen confound the estimation of instream metabolic processes at this site for those days when the hydroelectric plant was in operation. During this study, the plant operated essentially all of the 2000 growing season and all but 26 days in late summer of 2001 when streamflow conditions were too low to allow hydroelectric-power generation. It was on several days during this period in 2001 that primary productivity in the diminished streamflow of the Quinebaug River exceeded the maximum productivity rates estimated for the other three sites by a factor of 1.4 to 7.2 times.

Table 3. Primary productivity and respiration estimated from continuous monitors at sampling locations in the Quinebaug River Basin, Connecticut, water years 2000 and 2001.

[Values for primary productivity and respiration expressed as a rate of change in either a positive (increasing) or negative (decreasing) direction in grams of oxygen per cubic meter per hour $\left(\mathrm{g} \mathrm{O}_{2} / \mathrm{m}^{3} / \mathrm{hr}\right)$ for lowest, highest, or median values]

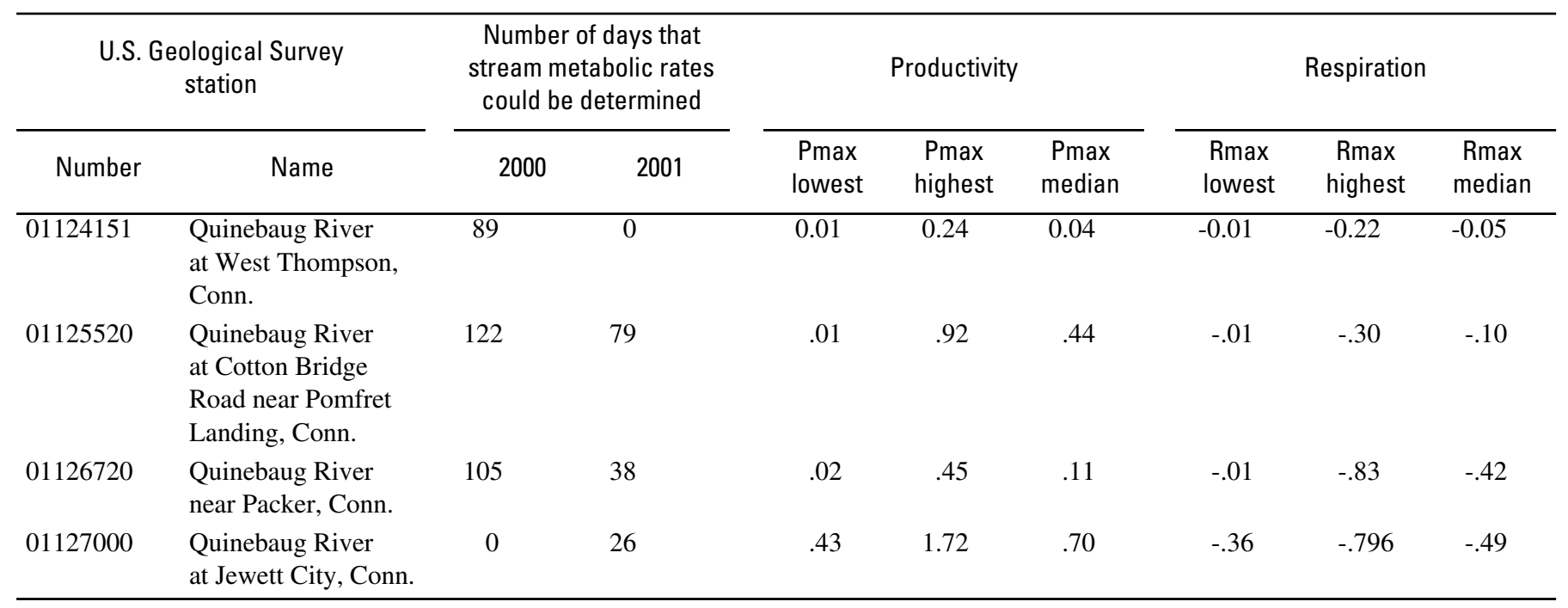



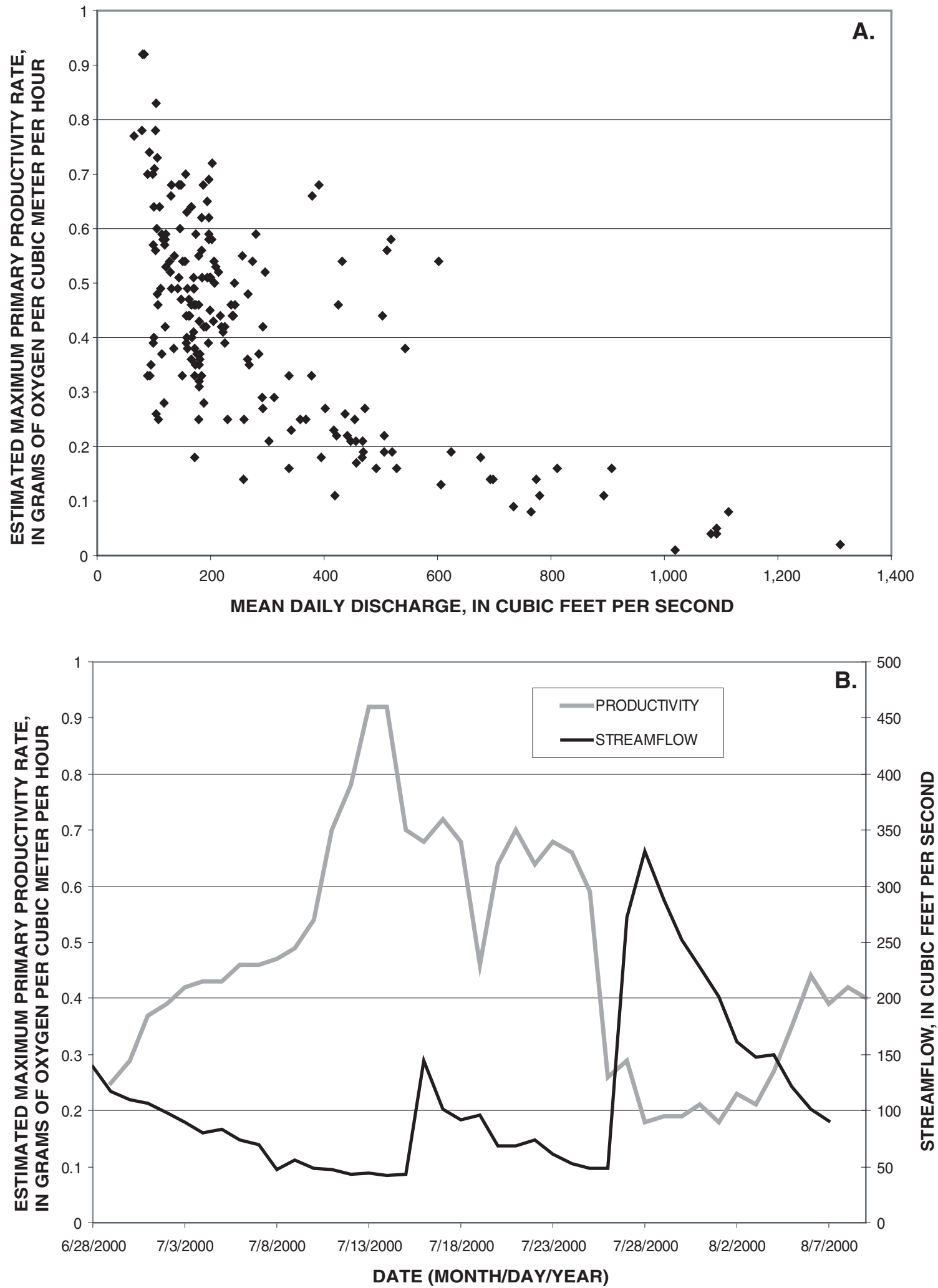

Figure 15. Estimated maximum primary productivity and streamflow of the Quinebaug River at U.S. Geological Survey station 01125520 , Cotton Bridge Road near Pomfret Landing, Connecticut. A. Variability with discharge. B. Variability with time. 


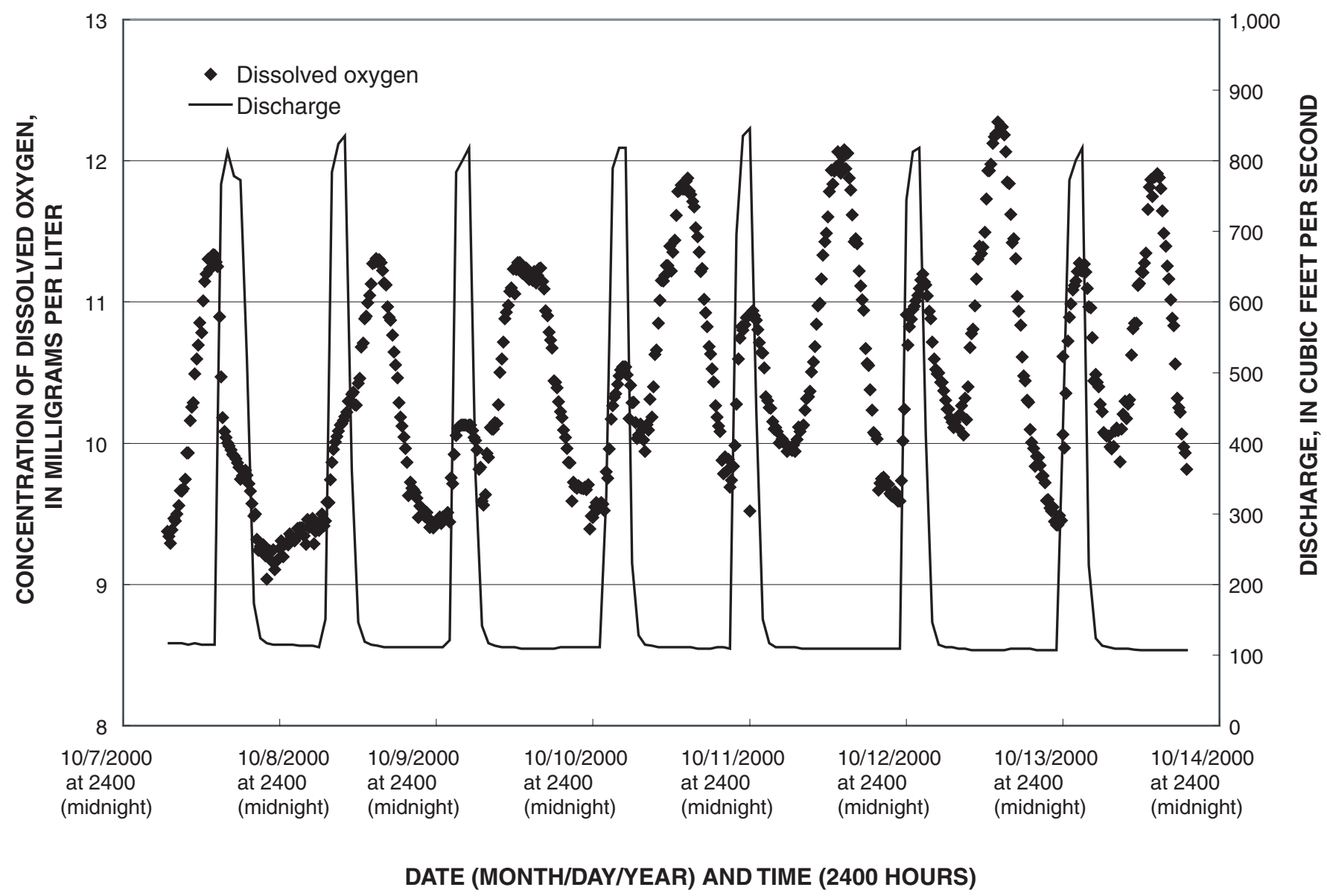

Figure 16. Effects of streamflow regulation on concentrations of dissolved oxygen at U.S. Geological Survey station 01127000, Quinebaug River at Jewett City, Connecticut. 
Ideally, a balance to a slight net gain between photosynthetic primary productivity and respiration is desired (to provide food for aquatic herbivores) with organic materials being decomposed by respiratory activity at about the same rate as they are produced through photosynthesis. The ratio of $\mathrm{P}_{\max }$ to $\mathrm{R}_{\max }$ is therefore, an indication of metabolic balance in the stream. When $P_{\max }$ greatly exceeds $R_{\max }$, algal biomass is accumulating faster than it can be consumed or decomposed, ultimately leading to an imbalance that may be exported downstream, potentially disturbing the metabolic balance of the receiving stream reach (Stumm and Morgan, 1981, p. 701). Plots of the $\mathrm{P}_{\max }$ to $\mathrm{R}_{\max }$ ratio from the continuous-monitorderived metabolic rates (fig. 17) indicate that there is a tendency toward excess productivity at the four sites monitored on the Quinebaug River during water years 2000 and 2001. About 60 percent of the time when both a productivity rate and a respiration rate were determined on the same day at any station, the $\mathrm{P}_{\max }$ to $\mathrm{R}_{\max }$ ratio exceeded 1.0. Productivity rates as much as 11 times greater than respiration rates were determined during some of the most productive periods monitored.

\section{Rates Determined from Light- and Dark-Bottle Measurements}

An alternative method to measure in-stream metabolic rates - the light-dark bottle experiments-was used to help evaluate the estimates produced from continuous-monitor data and to provide rate estimates at locations in the basin that were not monitored. Estimates of primary productivity and respiration were calculated from the measured difference between initial and final dissolved oxygen (DO) concentrations within each light and dark bottle after a known incubation time in the euphotic zone in the river (American Public Health Association and others, 1992).

Primary productivity $=$ light bottle DO - initial DO/incubation period

Respiration = initial DO - dark bottle DO/incubation period

Primary productivity and respiration rates from the light- and dark-bottle measurements conducted in the Quinebaug River Basin during the summer of 2001 are shown in table 4 .

At 6 of the 10 sites sampled, the light bottles had measurable increases of dissolved oxygen over the duration of the experiment allowing for quantification of primary production within the bottle. Conversely, at most sites, the dark bottles had a loss of oxygen as respiration continued in the absence of light. Results for several sites, however, were anomalous: a loss of oxygen in the light bottles occurred at the Little River, the Moosup River, and the Quinebaug River at Jewett City locations. No measurable dissolved oxygen loss occurred in the dark bottles from the French River and Quinebaug River at West Thompson, Connecticut, and no measurable change in dissolved oxygen was observed in either bottle at the Pachaug River location. Oxygen losses in the light bottles may be attributed to chemical oxygen demand and microbial activity that can occur when sample times exceed a few hours (Vollenweider,
1974; Hall and Moll, 1975). These anomalous dissolved oxygen measurements occurred principally in the tributaries, which are generally less nutrient-enriched, and may indicate that a significant seston algal population was not present or was not the dominant primary producer at that time. Periphyton (attached algae) and macrophyte growth have been observed at some of these sites and may be the principal crop in the tributary streams. Riskin and others (2003) have reported median periphyton chlorophyll-a concentrations of 5.4 milligrams per square meter from unimpaired reference streams in eastern Massachusetts that are similar to the Quinebaug tributaries.

The primary productivity and respiration rates in the light and dark bottles were variable throughout the basin (table 4). The highest productivity rate $\left(0.49 \mathrm{~g} \mathrm{O}_{2} / \mathrm{m}^{3} / \mathrm{hr}\right)$ was measured in the Quinebaug River at West Thompson. At three locations in the basin, the light- and dark-bottle data demonstrated negative primary productivity rates, indicating that oxygen consumption was substantially greater than oxygen production at these sites. These conditions may represent high biochemical oxygen demand in the stream that can exist downstream from wastewater-effluent discharges, but two of the sites (the Little River and Moosup River) are not waste-receiving streams. A comparison of the metabolic rates determined from the continuous-monitor data could only be accomplished at one location, the Quinebaug River at Cotton Bridge Road near Pomfret Landing, Conn. $\mathrm{P}_{\max }$ and $\mathrm{R}_{\max }$ rates from the continuous monitor dissolved oxygen data on July 24, 2001 were about twice the values obtained from the light- and dark-bottle measurements. The differences may be an artifact of comparing essentially instantaneous rates (determined from the light and dark bottles) for exclusively phytoplankton populations to time-averaged rates of primary production and respiration in the Quinebaug River aquatic community at large. It can be inferred, however, that about half the productivity in the Quinebaug River at this location was attributable to periphyton and macrophytes. 

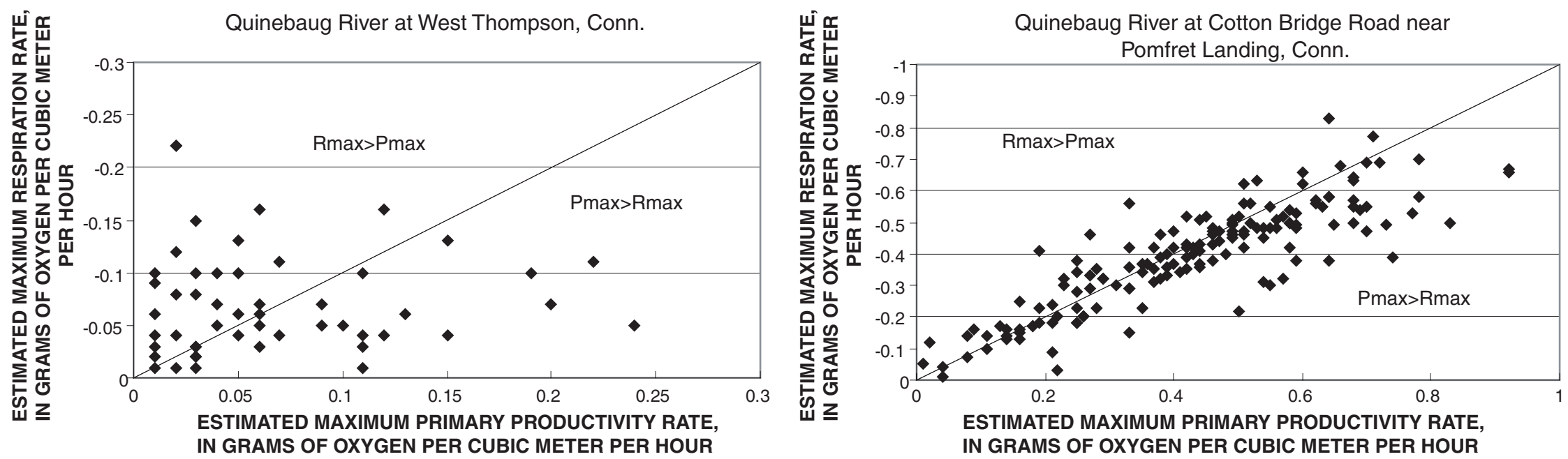

IN GRAMS OF OXYGEN PER CUBIC METER PER HOUR

IN GRAMS OF OXYGEN PER CUBIC METER PER HOUR
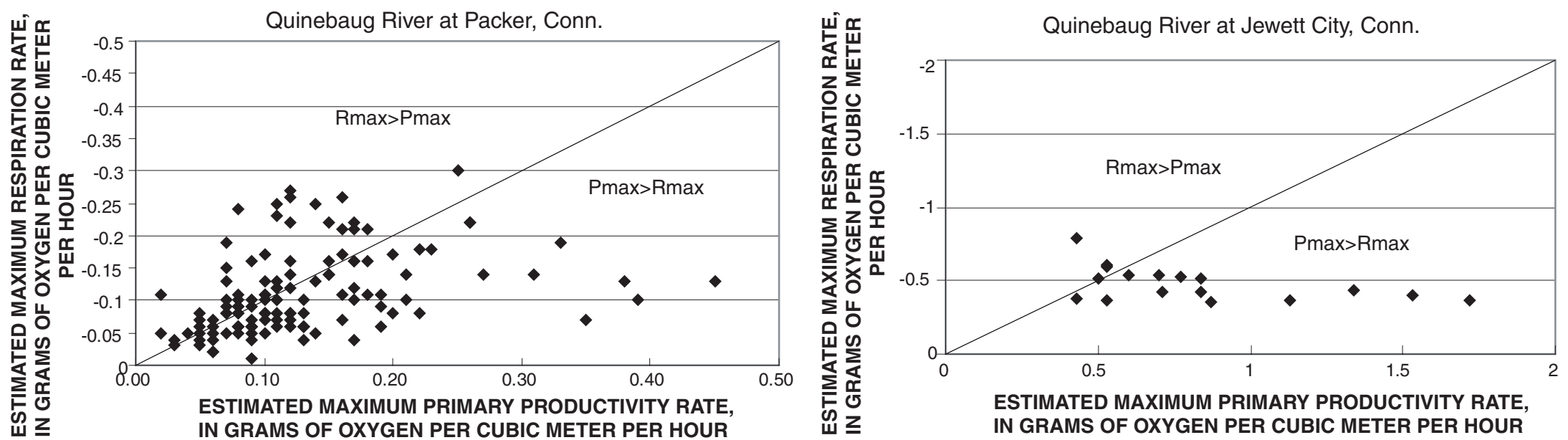

Figure 17. Ratio of estimated maximum primary productivity rate (Pmax) to estimated maximum respiration rate (Rmax) during water years 2000 and 2001 at four stations in the Quinebaug River Basin, Connecticut. 
Table 4. Primary productivity and respiration estimated from light and dark bottles at sampling locations in the Quinebaug River Basin, Connecticut, water year 2001.

[Values for primary productivity and respiration expressed as a rate of change in either a positive (increasing) or negative (decreasing) direction in grams of oxygen per cubic meter per hour $\left(\mathrm{g} \mathrm{O}_{2} / \mathrm{m}^{3} / \mathrm{hr}\right) ;--$, not sampled

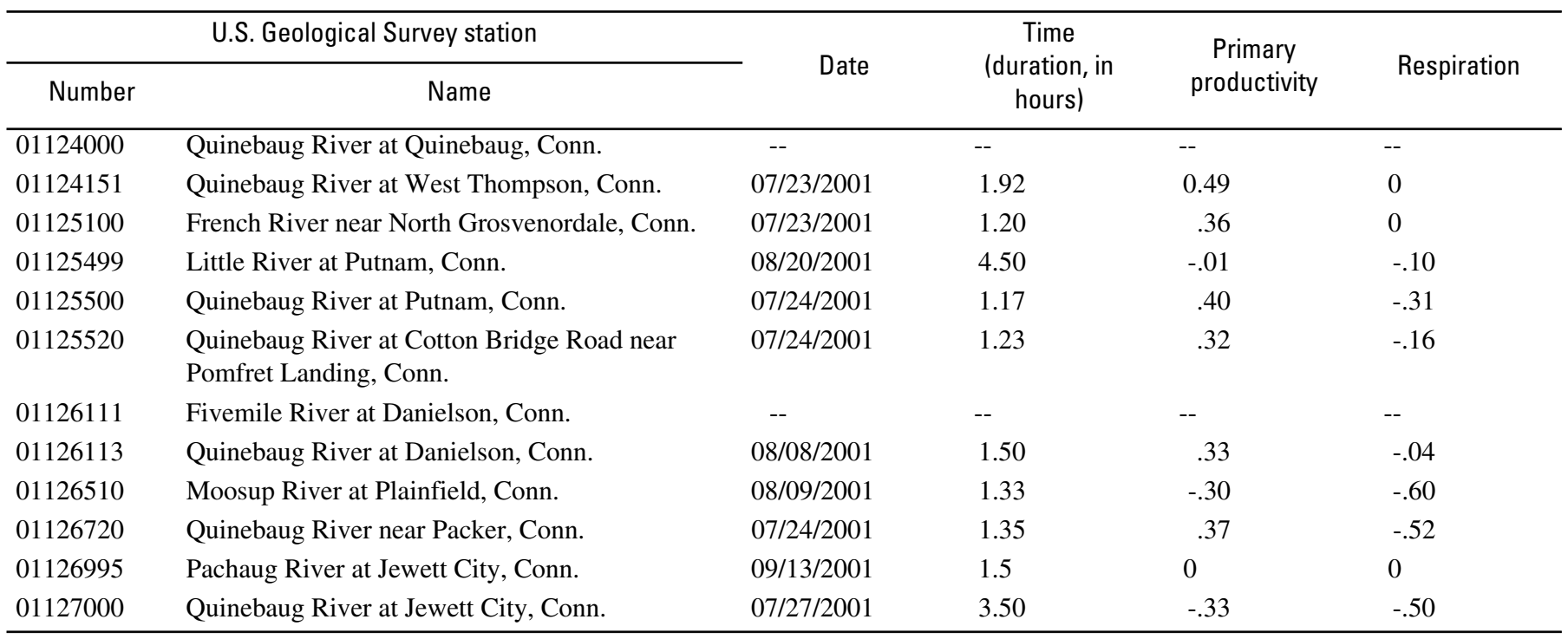

Phytoplankton dominance in the Quinebaug River is supported by the light- and dark-bottle data collected throughout the Quinebaug River Basin. Substantially increased concentrations of dissolved oxygen in the light bottles in the known absence of periphyton can be attributed only to seston productivity. Measurable loss of oxygen in the dark bottles (in the absence of other biota) indicates seston algal metabolism and/or other biochemical oxygen demand.

The daily primary cycle of productivity and respiration in the river also caused daily variability in $\mathrm{pH}$. As dissolved oxygen increases throughout the day during primary production by algae, $\mathrm{pH}$ values also increase as carbon dioxide is removed from the water (Stumm and Morgan, 1981, p. 195). Daily maximum $\mathrm{pH}$ values exceeding 9.0 (and ranging as high as 9.8) have been measured on 44 days during this study. Conversely, during night time hours $\mathrm{pH}$ values return to daily minima as carbon dioxide is produced and dissolved oxygen consumed. Generally, $\mathrm{pH}$ values recorded at the four continuously monitored stations seldom dropped much below 6.7 as the moderate alkalinity of the waters provided a natural buffering capacity. The lowest measured $\mathrm{pH}$ was 6.1 at the Quinebaug River at West Thompson on May 18, 2001. Dissolved oxygen concentrations less than $5 \mathrm{mg} / \mathrm{L}$, and as low as $2.5 \mathrm{mg} / \mathrm{L}$, however, were recorded on 34 days during the monitoring period. Extreme values of both $\mathrm{pH}$ and dissolved oxygen concentration may periodically be stressors on the aquatic health of the Quinebaug River Basin.

\section{Summary and Conclusions}

As part of the continuing effort to understand and improve water quality in Connecticut, the Connecticut Department of Environmental Protection and the U.S. Geological Survey began a cooperative study in 2002 to characterize the relation between nutrient enrichment and excessive algal productivity in the Quinebaug River Basin. Understanding where, when, and how elevated nutrient concentrations affect the rate of primary productivity in the Quinebaug River Basin may facilitate decisions by water-resource managers on how best to manage the water resources to minimize nuisance algal blooms. This may involve lowering maximum productivity rates and decreasing the length of time during which the blooms occur.

Water-quality samples collected in the Quinebaug River Basin during water years 2000 and 2001 substantiate a historically consistent and pervasive distribution of elevated total nitrogen and total phosphorus concentrations. Median total nitrogen concentrations equalled or exceeded the U.S. Environmental Protection Agency (USEPA) proposed regional total nitrogen ambient water-quality criterion of 0.71 milligrams per liter (mg/L), and maximum total nitrogen concentrations exceeded $1.0 \mathrm{mg} / \mathrm{L}$ in water samples from 9 of the 12 stations in the basin sampled for this study. Median total phosphorus concentrations also equalled or exceeded the USEPA's proposed regional total phosphorus ambient water-quality criterion of $0.031 \mathrm{mg} / \mathrm{L}$ in water samples from the same stations in the basin that demonstrated elevated total nitrogen concentrations. Maximum total phosphorus concentrations exceeded $0.1 \mathrm{mg} / \mathrm{L}$ at five of these stations. The elevated total nitrogen and total phos- 
phorus concentrations were evident at all Quinebaug River main-stem stations and at stations on two tributaries, the French River and Little River. The elevated concentrations at mainstem and French River stations are the result of municipal wastewater-treatment plants that discharge nitrogen- (and phosphorus-) enriched wastewater to the Quinebaug River and the French River upstream from the stations sampled. The elevated concentrations at the station on the Little River reflect the contribution of nonpoint sources of nutrients from the Little River drainage area, which contains 24 percent agricultural land.

Poor correlation between total nitrogen and total phosphorus concentrations in the Quinebaug River Basin ( $r=0.52)$ reflects differences in their sources as well as their transport mechanisms. A number of factors contribute to the weak total nitrogen:total phosphorus correlation, including the composition of fertilizers used on agricultural and residential land with formulations that often contain 10 to 50 times more nitrogen than phosphorus, the seasonal removal of phosphorus from some municipal wastewater effluents, differential aquatic attenuation processes, and the fact that nitrogen species largely are transported in a dissolved state whereas phosphorus species tend to adsorb to sediment particles.

Low streamflow, warm temperatures, and long hours of daylight all act together to promote algal growth in areas where concentrations of nutrients are elevated during summer and early fall. Measured phytoplankton densities ranged from 0 algal c/mL (cells per milliliter) in samples from four stations (at least once during the study), including two on the main stem of the Quinebaug River plus two tributaries, to an observed maximum of 85,000 algal $\mathrm{c} / \mathrm{mL}$ at the Quinebaug River near Packer, Connecticut, in September 2001. Phytoplankton densities exceeding 10,000 algal $\mathrm{c} / \mathrm{mL}$ were observed in 16 percent (12 of 77) of the phytoplankton samples collected over the two summers, most often during August and September 2001 at impounded or slow-moving reaches of the Quinebaug River. Generally, observed algal densities were lower during summer 2000 than in 2001. Streamflow in the summer of 2000 was consistently higher than in the summer of 2001, including a 2-week period in early August 2000 that likely would have flushed the standing crop of algae from impoundments, diluted nutrient concentrations, and carried more turbid waters that would hinder algal growth.

Chlorophyll-a concentration provides a reasonable estimate of algal biomass; concentrations in water samples from the Quinebaug River Basin during this study ranged from 0.2 to 42 $\mu \mathrm{g} / \mathrm{L}$ (micrograms per liter) and were highest in samples from the waste-receiving parts of the system-the French and Quinebaug Rivers-and were lowest in samples from the unimpaired tributaries - the Fivemile, Moosup, and Pachaug Rivers. Nearly half (49 percent) of all chlorophyll-a concentrations exceeded the USEPA's 3.75- $\mu \mathrm{g} / \mathrm{L}$ recommended regional water-quality criterion, but chlorophyll-a (and consequently, algal biomass) levels elevated above the $3.75-\mu \mathrm{g} / \mathrm{L}$ threshold were most often present (62 percent) in samples from the French and Quinebaug Rivers.
Two methods were used to estimate rates of primary productivity and respiration of algae in the Quinebaug River Basin. Dissolved oxygen concentrations from continuous water-quality monitor data were used to calculate rates of primary production $\left(\mathrm{P}_{\max }\right)$ and respiration $\left(\mathrm{R}_{\max }\right)$. Estimated maximum primary productivity and respiration rates, calculated as the difference between the minima and maxima over rapidly changing linear portions of the diel curves, were as high as $1.72 \mathrm{~g} \mathrm{O}_{2} / \mathrm{m}^{3} / \mathrm{hr}$ (grams of oxygen per cubic meter per hour) for the Quinebaug River at Jewett City, Connecticut. A diel dissolved oxygen change of $5.9 \mathrm{mg} / \mathrm{L}$ was also measured at this location on the same day, September 20, 2001, during a period of low streamflow. Productivity rates were greater than respiration rates about 60 percent of the time, suggesting that excessive algal production upstream can be exported to downstream locations, affecting downstream indicators of eutrophication and organic enrichment. The primary productivity and respiration calculated from dissolved oxygen data from continuous waterquality monitors demonstrated considerable seasonal and flowrelated variability, but also varied substantially on consecutive days.

Primary productivity and respiration rate estimates also were determined based on the light- and dark-bottle dissolved oxygen method. These rates, calculated as the difference between initial and final dissolved oxygen concentrations in the closed light and dark bottles after a known incubation time in the euphotic zone in the river, clearly indicated that most of the primary production in the Quinebaug River Basin occurs in the waste-receiving reaches of the main stem of the Quinebaug River and the French River. The highest metabolic rates, $\mathrm{P}_{\max }$ $0.49 \mathrm{~g} \mathrm{O}_{2} / \mathrm{m}^{3} / \mathrm{hr}$ at West Thompson and $\mathrm{R}_{\max }-0.52 \mathrm{~g} \mathrm{O}_{2} / \mathrm{m}^{3} / \mathrm{hr}$ at Packer, were recorded in the main stem Quinebaug River near impoundments. The light- and dark-bottle results also indicated the dominance of seston algae in the main stem Quinebaug River and French River, and the absence of seston algae and consequentially the more important role of periphyton and macrophytes on metabolic rates in the tributaries.

Changes in water quality as a result of primary productivity and respiration in the river were observed. Values of $\mathrm{pH}$ exceeded 9.0 standard units on several occasions during peak algal blooms. The diel effects of photosynthesis also include decreases in dissolved oxygen concentration below $5 \mathrm{mg} / \mathrm{L}$ (milligrams per liter) during respiration. The extreme values of both $\mathrm{pH}$ and dissolved oxygen concentration may periodically be stressors on the aquatic health of streams in the Quinebaug River Basin.

\section{Acknowledgments}

This study was conducted in cooperation with the Connecticut Department of Environmental Protection, and the authors wish to acknowledge information provided by Messrs. Fred Banach, Guy Hoffman, Terry Nelsen, Ernest Pizzuto, and Eric Thomas that was beneficial to this study. In particular, the 
efforts of Mr. Hoffman in performing all phytoplankton identification and enumeration are gratefully acknowledged herewith. Mr. Lawrence MacMillan with Region I, USEPA also provided useful information. The authors would like to thank the following USGS personnel: Jonathan Morrison and Stephen Porter for the suggestions that helped define the study; Karen Beaulieu, Bruce Davies 3rd, Jason Lewis, Joseph Martin, and Heather Sirotnak for sampling efforts and collection of field data; and Jeffrey Deacon, Stephen Porter, and Barbara Korzendorfer for suggestions that have improved this manuscript.

\section{References Cited}

American Public Health Association, American Water Works Association and Water Pollution Control Federation, 1992, Standard methods for the examination of water and wastewater $\left(18^{\text {th }}\right.$ ed.): Washington, D.C., American Public Health Association, $1134 \mathrm{p}$.

Brenton, R.W., and Arnett, T.L., 1993, Methods of analysis by the U.S. Geological Survey National Water-Quality Laboratory-Determination of dissolve organic carbon by UV-promoted persulfate oxidation and infrared spectrometry: U.S. Geological Survey Open-File Report 92-480, 12 p.

Britton, L. J., and Greeson, P. E., eds., 1989, Methods for collection and analysis of aquatic biological and microbiological samples: U.S. Geological Survey Techniques of WaterResources Investigations, book 5, chapter A4, $363 \mathrm{p}$.

Colombo, M.J., and Trench, E.C.T., 2002, Trends in surfacewater quality in Connecticut: U.S. Geological Survey WaterResources Investigations Report 02-4012, 39 p.

Connecticut Department of Environmental Protection, 1978, The causes of algae growth in Roseland Lake, Woodstock, Connecticut: Hartford, Conn., Bureau of Water Resources, $18 \mathrm{p}$.

Connecticut Department of Environmental Protection, 1994, 1994 Water quality report to Congress, prepared pursuant to Clean Water Act Section 305(b): Hartford, Conn., Bureau of Water Management, $97 \mathrm{p}$.

Connecticut Department of Environmental Protection, 1998a, Connecticut waterbodies not meeting water quality standards, prepared pursuant to Clean Water Act Section 303(d): Hartford, Conn., Bureau of Water Management, 32 p.

Connecticut Department of Environmental Protection, 1998b, Nutrient loadings in the Thames River basin: Hartford, Conn., Bureau of Water Management, [variously paged].

Connecticut Department of Environmental Protection, 2002, 2002 Water quality report to Congress, prepared pursuant to Clean Water Act Section 305(b): Hartford, Conn., Bureau of Water Management, [variously paged].

Fishman, M.J., ed., 1993, Methods of analysis by the U.S. Geological Survey National Water Quality Laboratory-Determination of inorganic and organic constituents in water and fluvial sediments: U. S. Geological Survey Open File Report 93-125, $217 \mathrm{p}$.
Fishman, M.J., and Friedman, L.C., eds., 1989, Methods for determination of inorganic substances in water and fluvial sediments: U.S. Geological Survey Techniques of WaterResources Investigations, book 5, chapter A1, $545 \mathrm{p}$.

Hall, C.A., and Moll, R., 1975, Methods of assessing aquatic primary productivity, in Lieth, H., and Whittaker, R.H., eds., Primary productivity of the biosphere: New York, Springer Verlag, p. 19-53.

Healy, D.F., and Kulp, K.P., 1995, Water-quality characteristics of selected public recreational lakes and ponds in Connecticut: U.S. Geological Survey Water-Resources Investigations Report 95-4098, 277 p.

Hem, J.D., 1985, Study and interpretation of the chemical characteristics of natural water (3rd ed.): U.S. Geological Survey Water-Supply Paper 2254, 263 p.

Kulp, K.P., 1991, Suspended-sediment characteristics of Muddy Brook at Woodstock, Connecticut, with a section on The water quality of Roseland Lake and its major tributaries, Muddy Brook and Mill Brook: Connecticut Water Resources Bulletin 43, 64 p.

Litke, D.W., 1999, Review of phosphorus control measures in the United States and their effects on water quality: U.S. Geological Survey Water-Resources Investigations Report 994007, $38 \mathrm{p}$.

Medalie, Laura, 1996, Wastewater collection and return flow in New England: U.S. Geological Survey Water-Resources Investigations Report 95-4144, 79 p.

Morrison, Jonathan, Davies, B.S. 3rd, Martin, J.W., and Norris, J.R., 2003, Water resources data, Connecticut, water year 2002: U.S. Geological Survey Water-Resources Data Report CT-02-1, 377 p.

Moulton, S. R. II, Kennen, J. G., Goldstein, R. M., and Hambrook, J. A., 2002, Revised protocols for sampling algal, invertebrate, and fish communities as part of the National Water-Quality Assessment Program: U. S. Geological Survey Open-File Report 00-150, 75 p.

Mueller, D.K., Hamilton, P.A., Helsel, D.R., Hitt, K.J., and Ruddy, B.C., 1995, Nutrients in ground water and surface water of the United States-An analysis of data through 1992: U.S. Geological Survey Water-Resources Investigations Report 95-4031, 74 p.

Odum, H. T., 1956, Primary production in flowing waters: Limnology and Oceanography, v. 1, no. 2, p.102-117.

Patton, C.J., and Truitt, E.P., 1992, Method of analysis by the U.S. Geological Survey National Water Quality Laboratory-Determination of total phosphorus by a Kjeldahl digestion method and an automated colorimetric finish that includes dialysis: U.S. Geological Survey Open File Report 92-146, $39 \mathrm{p}$.

Peterson, D.A., Porter, S.D., and Kinsey, S.M., 2001, Chemical and biological indicators of nutrient enrichment in the Yellowstone River basin, Montana and Wyoming, August 2000 - Study design and preliminary results: U.S. Geological Survey Water- Resources Investigations Report 01-4238, $6 \mathrm{p}$. 
Riskin, M.L., Deacon, J.R., Liebman, M.L., and Robinson, K.W., 2003, Nutrient and chlorophyll relations in selected streams of the New England coastal basins in Massachusetts and New Hampshire, June-September 2001: U.S. Geological Survey Water-Resources Investigations Report 03-4191, $16 \mathrm{p}$.

Shelton, L.R., 1994, Field guide for collection and processing stream-water samples for the National Water Quality assessment program: U. S. Geological Survey Open-File Report 94-455, $42 \mathrm{p}$.

Sorenson, S.K., Porter, S.D., Akers, K.B., Harris, M.A., Kalkhoff, S.J., Lee, K.E., Roberts, L.R., and Terrio, P.J., 1999, Water quality and habitat conditions in the upper Midwest streams in relation to riparian vegetation and soil characteristics, August 1997-Study design, methods, and data: U.S. Geological Survey Open-File Report 99-202, 53 p.

Stumm, Werner, and Morgan, J.J., 1981, Aquatic chemistry-An introduction emphasizing chemical equilibria in natural waters (2nd ed.): New York, John Wiley \& Sons, 780 p.

Trench, E.C.T., 1996, Trends in surface-water quality in Connecticut, 1969-88: U.S. Geological Survey Water-Resources Investigations Report 96-4161, $176 \mathrm{p}$.

Trench, E.C.T., 2000, Nutrient sources and loads in the Connecticut, Housatonic, and Thames River Basins: U.S. Geological Survey Water-Resources Investigations Report 994236, $66 \mathrm{p}$.

Trench, E.C.T., 2004, Analysis of phosphorus trends and evaluation of sampling designs in the Quinebaug River Basin, Connecticut: U.S. Geological Survey Scientific Investigations Report 2004-5094, 24 p.

U.S. Environmental Protection Agency, 1986, Quality criteria for water, 1986: Washington, D.C., U.S. Environmental Protection Agency Report 440/5-86-001, Office of Water, [variously paged].

U.S. Environmental Protection Agency, 1998, National strategy for the development of regional nutrient criteria: Washington, D.C., U.S. Environmental Protection Agency Report 822-R-98-002, Office of Water., $47 \mathrm{p}$.

U.S. Environmental Protection Agency, 2000a, Ambient water quality criteria recommendations-Information supporting the development of state and tribal nutrient criteria for rivers and streams in nutrient ecoregion XIV: Washington, D.C., U.S. Environmental Protection Agency Report 822-B-00022, Office of Water, [variously paged].

U.S. Environmental Protection Agency, 2000b, Nutrient criteria technical guidance manual-Rivers and streams: Washington, D.C., U.S. Environmental Protection Agency Report 822-B-00-002, Office of Water, [variously paged].

Vollenweider, R.A., ed., 1974, A manual on methods for measuring primary production in aquatic environments ( $2 \mathrm{~d} \mathrm{ed}$.): Oxford and Edinburgh, Blackwell Scientific Publications, International Biological Programme Handbook 12, 225 p.

Wagner, R.J., Mattraw, H.C., Ritz, G.F., and Smith, B.A., 2000, Guidelines and standard procedures for continuous waterquality monitors-Site selection, field operation, calibration, record computation, and reporting: U.S. Geological Survey Water-Resources Investigations Report 00-4252, 53 p.

Ward, J.R., and Harr, C.A., eds., 1990, Methods for collection and processing of surface-water and bed-material samples for physical and chemical analyses: U.S. Geological Survey Open-File Report 90-140, 71 p.

Wershaw, R.L., Fishman, M.J., Grabbe, R.R., and Lowe, L.E., 1987, Methods for determination of organic substances in water and fluvial sediments: Techniques of Water-Resources Investigations of the U.S. Geological Survey, book 5, chapter A3, $80 \mathrm{p}$.

Wetzel, R.G., 1983, Limnology: Harcourt Brace, 767 p.

Wilde, F.D., and Radtke, D.B., eds., 1998, National field manual for the collection of water quality data-Field measurements: U.S. Geological Survey Techniques of WaterResources Investigations, book 9, chapter A6., variously paged. 


\section{Appendixes 1-5}

Appendix 1 - 4. Continuous water-quality monitor data and estimated maximum rates of instream metabolic processes at:

1. Station 01124151, Quinebaug River at West Thompson, Conn.

2. Station 01125520, Quinebaug River at Cotton Bridge Road near Pomfret Landing, Conn.

3. Station 01126720, Quinebaug River near Packer, Conn.

4. Station 01127000, Quinebaug River at Jewett City, Conn.

Appendix 5. Seston algal abundance by taxa in water samples collected from the Quinebaug River Basin, Connecticut, water years 2000 and 2001 
Appendixes 1 - 5

Appendix 1 
Appendix 1. Continuous water-quality monitor data and estimated maximum rates of instream metabolic processes at station 01124151, Quinebaug River at West Thompson, Conn.

[mg/L, milligrams per liter; $\mathrm{P}_{\max }$ (maximum rate of productivity) and $\mathrm{R}_{\max }$ (maximum rate of respiration) in grams of oxygen per cubic meter per hour $\left(\mathrm{g} \mathrm{O}_{2} / \mathrm{m}^{3} / \mathrm{hr}\right.$ ) estimated from diel changes in dissolved oxygen concentrations; $\mu \mathrm{S} / \mathrm{cm}$, microsiemens per centimeter at 25 degrees Celsius; --, data not available due to partial record; nd, not determined due to equipment malfunction or changes in dissolved oxygen concentration that result from rapid changes in streamflow]

\begin{tabular}{|c|c|c|c|c|c|c|c|c|c|c|c|c|c|}
\hline \multirow[t]{2}{*}{ Date } & \multicolumn{3}{|c|}{$\begin{array}{l}\text { Dissolved oxygen } \\
\text { (mg/L) }\end{array}$} & \multicolumn{2}{|c|}{$\begin{array}{l}\text { Productivity/ } \\
\text { respiration }\end{array}$} & \multicolumn{2}{|c|}{$\begin{array}{c}\mathrm{pH} \\
\text { (standard units) }\end{array}$} & \multicolumn{3}{|c|}{$\begin{array}{l}\text { Specific conductance } \\
(\mu \mathrm{S} / \mathrm{cm})\end{array}$} & \multicolumn{3}{|c|}{$\begin{array}{l}\text { Water temperature } \\
\text { (degrees Celsius) }\end{array}$} \\
\hline & Max & Min & Mean & Pmax & Rmax & Max & Min & Max & Min & Mean & Max & Min & Mean \\
\hline $05-11-00$ & 10.3 & 9.9 & 10.1 & nd & nd & 7.1 & -- & 140 & 133 & -- & -- & 18.0 & -- \\
\hline $05-12-00$ & 10.8 & 9.9 & 10.5 & nd & nd & 6.9 & 6.8 & 141 & 137 & 140 & 18.0 & 16.0 & 16.5 \\
\hline $05-13-00$ & 10.8 & 10.7 & 10.8 & nd & nd & 6.9 & 6.9 & 143 & 141 & 142 & 16.5 & 16.0 & 16.0 \\
\hline $05-14-00$ & 10.9 & 10.8 & 10.8 & nd & nd & 7.1 & 6.9 & 143 & 138 & 141 & 17.5 & 16.0 & 16.5 \\
\hline $05-15-00$ & 10.9 & 10.8 & 10.9 & nd & nd & 7.0 & 6.9 & 138 & 136 & 137 & 17.0 & 16.5 & 17.0 \\
\hline $05-16-00$ & 10.9 & 10.5 & 10.7 & nd & nd & 7.0 & 6.9 & 140 & 138 & 139 & 17.5 & 16.0 & 17.0 \\
\hline $05-17-00$ & 10.8 & 10.5 & 10.6 & nd & nd & 7.0 & 6.8 & 141 & 139 & 139 & 17.0 & 16.0 & 16.5 \\
\hline $05-18-00$ & 10.6 & 10.4 & 10.5 & nd & nd & 7.0 & 6.9 & 144 & 141 & 142 & 17.5 & 16.5 & 17.0 \\
\hline $05-19-00$ & 10.7 & 10.4 & 10.5 & nd & nd & 7.0 & 6.9 & 143 & 135 & 139 & 17.5 & 16.0 & 16.5 \\
\hline $05-20-00$ & 11.1 & 10.6 & 10.8 & nd & nd & 6.9 & 6.8 & 136 & 129 & 132 & 16.0 & 14.5 & 15.5 \\
\hline $05-21-00$ & 11.2 & 10.3 & 11.1 & nd & nd & 6.9 & 6.8 & 130 & 128 & 128 & 14.5 & 14.0 & 14.5 \\
\hline $05-22-00$ & 11.3 & 10.4 & 11.2 & nd & nd & 6.9 & 6.8 & 131 & 129 & 130 & 14.0 & 14.0 & 14.0 \\
\hline $05-23-00$ & 11.3 & 11.0 & 11.1 & nd & nd & 6.9 & 6.8 & 129 & 128 & 129 & 14.5 & 14.0 & 14.0 \\
\hline $05-24-00$ & 11.0 & 10.7 & 10.9 & nd & nd & 7.0 & 6.9 & 129 & 124 & 127 & 16.5 & 14.5 & 15.0 \\
\hline $05-25-00$ & 10.7 & 10.5 & 10.6 & nd & nd & 7.0 & 6.9 & 125 & 122 & 124 & 17.5 & 15.5 & 16.5 \\
\hline $05-26-00$ & 10.6 & 10.4 & 10.5 & nd & nd & 7.0 & 6.9 & 124 & 122 & 123 & 18.0 & 16.5 & 17.5 \\
\hline $05-27-00$ & 10.4 & 10.2 & 10.3 & nd & nd & 7.1 & 6.9 & 125 & 123 & 124 & 18.5 & 17.5 & 18.0 \\
\hline $05-28-00$ & 10.3 & 10.0 & 10.2 & nd & nd & 7.0 & 6.9 & 125 & 124 & 124 & 18.5 & 18.0 & 18.0 \\
\hline $05-29-00$ & 10.2 & 10.0 & 10.1 & nd & nd & 7.0 & 6.9 & 128 & 125 & 126 & 18.0 & 17.0 & 17.5 \\
\hline $05.30-00$ & 10.2 & 9.9 & 10.0 & nd & nd & 6.9 & 6.8 & 131 & 127 & 129 & 17.0 & 16.5 & 17.0 \\
\hline $05-31-00$ & 9.9 & 9.6 & 9.8 & nd & nd & 6.9 & 6.8 & 134 & 131 & 132 & 17.5 & 16.5 & 16.5 \\
\hline $06-01-00$ & 9.9 & -- & -- & nd & nd & 6.9 & -- & -- & 133 & -- & -- & -- & -- \\
\hline $06-16-00$ & -- & 9.1 & -- & nd & nd & 6.9 & -- & 121 & -- & -- & 19.0 & -- & -- \\
\hline $06-17-00$ & 9.1 & 8.8 & 9.0 & nd & nd & 7.1 & 6.9 & 119 & 117 & 118 & 22.5 & 19.0 & 20.5 \\
\hline $06-18-00$ & 8.8 & 8.7 & 8.8 & nd & nd & 7.0 & 6.9 & 118 & 116 & 117 & 22.5 & 22.0 & 22.0 \\
\hline 06-19-00 & 8.8 & 8.6 & 8.7 & nd & nd & 6.9 & 6.8 & 120 & 117 & 119 & 22.0 & 21.0 & 21.5 \\
\hline $06-20-00$ & 9.0 & 8.7 & 8.8 & nd & nd & 7.0 & 6.8 & 124 & 119 & 120 & 23.0 & 20.5 & 21.5 \\
\hline $06-21-00$ & 8.8 & 8.4 & 8.6 & nd & nd & 6.9 & 6.7 & 124 & 121 & 123 & 22.0 & 20.5 & 21.5 \\
\hline $06-22-00$ & 8.7 & 8.4 & 8.6 & nd & nd & 7.0 & 6.9 & 125 & 121 & 123 & 22.5 & 21.5 & 22.0 \\
\hline $06-23-00$ & 8.9 & 8.5 & 8.7 & nd & nd & 7.4 & 6.9 & 127 & 124 & 125 & 24.5 & 22.5 & 23.5 \\
\hline $06-24-00$ & 8.6 & 8.2 & 8.5 & nd & nd & 7.2 & 6.9 & 128 & 125 & 127 & 24.0 & 22.5 & 23.5 \\
\hline $06-25-00$ & 8.5 & 7.6 & 8.1 & nd & nd & 7.0 & 6.8 & 129 & 127 & 128 & 23.5 & 22.5 & 23.0 \\
\hline $06-26-00$ & 8.4 & 7.9 & 8.2 & nd & nd & 7.2 & 6.9 & 132 & 128 & 129 & 24.5 & 23.5 & 24.0 \\
\hline $06-27-00$ & 8.3 & 7.3 & 8.1 & nd & nd & 9.0 & 6.9 & 138 & 128 & 132 & 25.5 & 24.0 & 24.5 \\
\hline $06-28-00$ & 8.3 & 7.8 & 8.1 & nd & nd & 7.9 & 7.1 & 137 & 135 & 136 & 26.9 & 24.5 & 25.0 \\
\hline $06-29-00$ & 8.0 & 7.4 & 7.8 & nd & nd & 7.3 & 6.8 & 137 & 135 & 136 & 25.0 & 24.0 & 24.5 \\
\hline $06-30-00$ & 8.5 & 7.5 & 8.1 & 0.03 & -0.15 & 8.0 & 6.8 & 137 & 135 & 136 & 25.5 & 24.0 & 24.5 \\
\hline 07-01-00 & 8.1 & 7.4 & 7.8 & .02 & -.21 & 7.4 & 6.9 & 139 & 135 & 136 & 26.0 & 24.5 & 25.0 \\
\hline $07-02-00$ & 7.9 & 7.1 & 7.5 & .02 & -.12 & 7.0 & 6.8 & 140 & 136 & 138 & 25.0 & 24.0 & 24.5 \\
\hline $07-03-00$ & 7.9 & 7.1 & 7.5 & .01 & -.09 & 7.0 & 6.8 & 143 & 137 & 140 & 24.5 & 24.0 & 24.5 \\
\hline 07-04-00 & 7.4 & 7.4 & 7.6 & .03 & -.10 & 7.0 & 6.8 & 142 & 140 & 141 & 25.5 & 24.0 & 24.5 \\
\hline $07-05-00$ & 8.1 & 7.3 & 7.7 & .06 & -.06 & 7.2 & 6.8 & 143 & 138 & 141 & 26.5 & 24.5 & 25.5 \\
\hline 07-06-00 & 8.1 & 7.5 & 7.7 & .05 & -.13 & 7.2 & 6.9 & 145 & 140 & 142 & 26.5 & 25.0 & 25.5 \\
\hline
\end{tabular}


Appendix 1. Continuous water-quality monitor data and estimated maximum rates of instream metabolic processes at station 01124151, Quinebaug River at West Thompson, Conn.-Continued

$\left[\mathrm{mg} / \mathrm{L}\right.$, milligrams per liter; $\mathrm{P}_{\max }$ (maximum rate of productivity) and $\mathrm{R}_{\max }$ (maximum rate of respiration) in grams of oxygen per cubic meter per hour $\left(\mathrm{g} \mathrm{O}_{2} / \mathrm{m}^{3} / \mathrm{hr}\right.$ ) estimated from diel changes in dissolved oxygen concentrations; $\mu \mathrm{S} / \mathrm{cm}$, microsiemens per centimeter at 25 degrees Celsius; --, data not available due to partial record; nd, not determined due to equipment malfunction or changes in dissolved oxygen concentration that result from rapid changes in streamflow]

\begin{tabular}{|c|c|c|c|c|c|c|c|c|c|c|c|c|c|}
\hline \multirow[t]{2}{*}{ Date } & \multicolumn{3}{|c|}{$\begin{array}{l}\text { Dissolved oxygen } \\
\text { (mg/L) }\end{array}$} & \multicolumn{2}{|c|}{$\begin{array}{l}\text { Productivity/ } \\
\text { respiration }\end{array}$} & \multicolumn{2}{|c|}{$\begin{array}{c}\mathrm{pH} \\
\text { (standard units) }\end{array}$} & \multicolumn{3}{|c|}{$\begin{array}{l}\text { Specific conductance } \\
\qquad(\mu \mathrm{S} / \mathrm{cm})\end{array}$} & \multicolumn{3}{|c|}{$\begin{array}{l}\text { Water temperature } \\
\text { (degrees Celsius) }\end{array}$} \\
\hline & Max & Min & Mean & Pmax & $R \max$ & $\operatorname{Max}$ & Min & Max & Min & Mean & Max & Min & Mean \\
\hline $07-07-00$ & 8.6 & 7.6 & 8.1 & .0 & -.11 & 7.8 & 6.8 & 146 & 141 & 145 & 26.0 & 25.0 & 25.5 \\
\hline $07-08-00$ & 8.7 & 8.2 & 8.5 & .01 & -.03 & 7.6 & 7.2 & 148 & 142 & 146 & 25.0 & 24.0 & 24.5 \\
\hline 07-09-00 & 8.4 & 7.8 & 8.2 & nd & -.03 & 7.3 & 6.8 & 155 & 144 & 148 & 24.0 & 22.5 & 23.5 \\
\hline $07-10-00$ & 8.3 & 7.7 & 8.0 & .09 & -.07 & 7.6 & 6.8 & 151 & 115 & 133 & 24.5 & 23.0 & 23.5 \\
\hline $07-11-00$ & 8.8 & 7.8 & 8.4 & .04 & -.10 & 8.7 & 7.1 & 117 & 116 & 116 & 25.5 & 23.5 & 24.5 \\
\hline $07-12-00$ & 9.0 & 8.2 & 8.6 & .02 & -.22 & 8.9 & 7.4 & 120 & 116 & 118 & 26.0 & 24.0 & 25.0 \\
\hline $07-13-00$ & 8.2 & 7.5 & 7.9 & .04 & nd & 7.9 & 7.0 & 121 & 117 & 119 & 25.0 & 23.5 & 24.0 \\
\hline $07-14-00$ & 8.2 & 7.2 & 7.6 & nd & nd & 7.2 & 6.9 & 123 & 120 & 121 & 24.5 & 23.5 & 23.5 \\
\hline $07-15-00$ & 8.3 & 7.4 & 7.8 & .10 & nd & 7.8 & 7.0 & 122 & 115 & 121 & 24.0 & 23.5 & 24.0 \\
\hline $07-16-00$ & 8.6 & 7.7 & 8.2 & nd & -.16 & 8.4 & 7.2 & 154 & 118 & 123 & 24.5 & 23.5 & 24.0 \\
\hline $07-17-00$ & 8.7 & 8.2 & 8.4 & nd & nd & 8.9 & 7.4 & 161 & 153 & 157 & 25.0 & 24.0 & 24.5 \\
\hline $07-18-00$ & 8.7 & 8.1 & 8.3 & nd & nd & 8.9 & 7.2 & 162 & 159 & 161 & 25.0 & 24.0 & 24.5 \\
\hline 07-19-00 & 9.1 & 8.7 & 8.9 & nd & nd & 9.2 & 8.8 & 163 & 161 & 162 & 24.5 & 24.0 & 24.5 \\
\hline $07-20-00$ & 10.0 & 8.4 & 8.9 & nd & nd & 9.3 & 7.0 & 179 & 161 & 171 & 25.0 & 23.5 & 24.0 \\
\hline $07-21-00$ & 8.5 & 8.1 & 8.3 & .22 & -.08 & 8.6 & 7.1 & 182 & 177 & 180 & 24.0 & 22.5 & 23.0 \\
\hline $07-22-00$ & 8.9 & 8.1 & 8.5 & .11 & -.23 & 9.2 & 7.1 & 181 & 178 & 179 & 25.0 & 23.0 & 24.0 \\
\hline $07-23-00$ & 9.6 & 8.3 & 8.8 & .10 & -.13 & 9.5 & 8.5 & 185 & 179 & 181 & 25.5 & 23.5 & 24.5 \\
\hline $07-24-00$ & 8.6 & 7.8 & 8.3 & .15 & -.16 & 9.1 & 7.7 & 180 & 177 & 179 & 25.0 & 23.5 & 24.5 \\
\hline $07-25-00$ & 9.4 & 7.8 & 8.5 & .12 & -.16 & 9.2 & 8.0 & 180 & 177 & 178 & 24.5 & 23.5 & 24.0 \\
\hline $07-26-00$ & 9.8 & 8.8 & 9.3 & .07 & -.13 & 9.3 & 8.9 & 180 & 177 & 179 & 23.5 & 23.0 & 23.5 \\
\hline $07-27-00$ & 9.4 & 8.9 & 9.2 & .06 & nd & 9.1 & 7.9 & 178 & 173 & 174 & 23.0 & 22.0 & 22.5 \\
\hline $07-28-00$ & 9.3 & 9.0 & 9.2 & .19 & -.11 & 7.9 & 7.0 & 173 & 163 & 170 & 22.0 & 20.5 & 21.5 \\
\hline $07-29-00$ & 9.3 & 9.1 & 9.2 & .17 & -.16 & 7.0 & 6.8 & 164 & 159 & 161 & 21.0 & 20.0 & 20.5 \\
\hline $07-30-00$ & 9.3 & 9.1 & 9.2 & .13 & -.10 & 7.2 & 6.8 & 163 & 158 & 160 & 21.5 & 20.5 & 21.0 \\
\hline $07-31-00$ & 9.2 & 9.0 & 9.1 & .09 & -.06 & 7.2 & 6.9 & 162 & 153 & 158 & 21.5 & 21.0 & 21.5 \\
\hline 08-01-00 & 9.0 & 8.8 & 9.0 & .08 & -.10 & 7.0 & 6.8 & 156 & 150 & 152 & 21.5 & 21.0 & 21.0 \\
\hline $08-02-00$ & 9.1 & 8.7 & 8.8 & .10 & -.17 & 7.1 & 6.7 & 152 & 139 & 144 & 21.0 & 20.5 & 21.0 \\
\hline 08-03-00 & 8.7 & 8.5 & 8.6 & nd & nd & 6.9 & 6.8 & 141 & 139 & 140 & 22.0 & 20.5 & 21.0 \\
\hline 08-04-00 & 8.8 & 8.4 & 8.6 & nd & nd & 8.2 & 6.9 & 141 & 140 & 140 & 24.5 & 22.0 & 23.0 \\
\hline $08-05-00$ & 8.5 & 8.1 & 8.4 & nd & nd & 8.2 & 7.0 & 141 & 140 & 141 & 25.0 & 23.0 & 24.0 \\
\hline 08-06-00 & 8.3 & 7.8 & 8.1 & nd & nd & 7.1 & 6.8 & 144 & 141 & 142 & 23.5 & 22.5 & 23.0 \\
\hline $08-07-00$ & 8.0 & 7.7 & 7.9 & .05 & -.06 & 7.0 & 6.8 & 145 & 143 & 144 & 24.0 & 22.5 & 23.0 \\
\hline $08-08-00$ & 8.3 & 7.7 & 8.0 & nd & -.12 & 8.6 & 6.9 & 147 & 144 & 145 & 26.0 & 23.5 & 24.5 \\
\hline 08-09-00 & 8.0 & 7.6 & 8.9 & nd & -.04 & 7.3 & 6.9 & 150 & 146 & 148 & 25.0 & 24.0 & 24.5 \\
\hline $08-15-00$ & 8.9 & -- & -- & nd & -.04 & 8.4 & -- & 159 & -- & -- & 23.0 & -- & -- \\
\hline $08-16-00$ & 8.4 & 8.1 & 8.2 & .02 & -.04 & 7.4 & 7.0 & 165 & 158 & 162 & 22.5 & 21.5 & 22.0 \\
\hline $08-17-00$ & 8.7 & 8.3 & 8.5 & .05 & -.04 & 8.1 & 7.1 & 165 & 161 & 162 & 22.5 & 21.5 & 22.0 \\
\hline $08-18-00$ & 8.8 & 8.5 & 8.7 & nd & -.08 & 7.5 & 7.2 & 167 & 164 & 165 & 22.0 & 21.5 & 21.5 \\
\hline $08-19-00$ & 8.8 & 8.2 & 8.6 & nd & nd & 8.4 & 7.1 & 169 & 166 & 167 & 23.0 & 21.0 & 22.0 \\
\hline $08-20-00$ & 9.0 & 8.0 & 8.7 & nd & nd & 8.7 & 7.3 & 170 & 168 & 169 & 22.5 & 21.5 & 22.0 \\
\hline $08-21-00$ & 9.3 & 8.9 & 9.1 & nd & -.03 & 8.9 & 7.7 & 171 & 169 & 170 & 22.5 & 21.0 & 22.0 \\
\hline $08-22-00$ & 9.1 & 8.4 & 8.9 & nd & -.10 & 8.5 & 7.3 & 173 & 170 & 171 & 22.0 & 21.0 & 21.5 \\
\hline $08-23-00$ & 8.6 & 8.3 & 8.5 & nd & nd & 7.3 & 7.0 & 173 & 171 & 172 & 21.0 & 20.5 & 20.5 \\
\hline
\end{tabular}


Appendix 1. Continuous water-quality monitor data and estimated maximum rates of instream metabolic processes at station 01124151, Quinebaug River at West Thompson, Conn.-Continued

[mg/L, milligrams per liter; $\mathrm{P}_{\max }$ (maximum rate of productivity) and $\mathrm{R}_{\max }$ (maximum rate of respiration) in grams of oxygen per cubic meter per hour $\left(\mathrm{g} \mathrm{O}_{2} / \mathrm{m}^{3} / \mathrm{hr}\right.$ ) estimated from diel changes in dissolved oxygen concentrations; $\mu \mathrm{S} / \mathrm{cm}$, microsiemens per centimeter at 25 degrees Celsius; --, data not available due to partial record; nd, not determined due to equipment malfunction or changes in dissolved oxygen concentration that result from rapid changes in streamflow]

\begin{tabular}{|c|c|c|c|c|c|c|c|c|c|c|c|c|c|}
\hline \multirow[t]{2}{*}{ Date } & \multicolumn{3}{|c|}{$\begin{array}{l}\text { Dissolved oxygen } \\
\text { (mg/L) }\end{array}$} & \multicolumn{2}{|c|}{$\begin{array}{l}\text { Productivity/ } \\
\text { respiration }\end{array}$} & \multicolumn{2}{|c|}{$\begin{array}{c}\mathrm{pH} \\
\text { (standard units) }\end{array}$} & \multicolumn{3}{|c|}{$\begin{array}{l}\text { Specific conductance } \\
\qquad(\mu \mathrm{S} / \mathrm{cm})\end{array}$} & \multicolumn{3}{|c|}{$\begin{array}{l}\text { Water temperature } \\
\text { (degrees Celsius) }\end{array}$} \\
\hline & Max & Min & Mean & Pmax & Rmax & Max & Min & Max & Min & Mean & Max & Min & Mean \\
\hline $08-24-00$ & 8.9 & 8.4 & 8.6 & .03 & -.01 & 8.9 & 7.1 & 172 & 171 & 171 & 23.0 & 20.5 & 21.5 \\
\hline $08-25-00$ & 8.7 & 8.2 & 8.4 & .01 & -.04 & 9.2 & 7.4 & 173 & 171 & 172 & 23.5 & 21.0 & 22.0 \\
\hline $08-26-00$ & 8.4 & 8.0 & 8.2 & .04 & nd & 8.5 & 7.3 & 172 & 170 & 171 & 22.5 & 21.0 & 21.5 \\
\hline $08-27-00$ & 8.5 & 8.0 & 8.2 & nd & -.06 & 8.9 & 7.8 & 171 & 169 & 170 & 22.5 & 21.5 & 22.0 \\
\hline $08-28-00$ & 8.6 & 7.9 & 8.2 & .11 & -.03 & 9.2 & 8.4 & 172 & 170 & 171 & 23.0 & 22.0 & 22.5 \\
\hline 08-29-00 & 10.6 & 7.9 & 9.2 & nd & nd & 8.9 & 7.2 & 173 & 170 & 172 & 22.5 & 22.0 & 22.0 \\
\hline $08-30-00$ & 11.4 & 10.0 & 10.7 & nd & nd & 9.0 & 7.5 & 174 & 173 & 173 & 23.0 & 22.0 & 22.0 \\
\hline $08-31-00$ & 11.2 & 9.7 & 10.2 & nd & nd & 8.8 & 7.1 & 176 & 173 & 174 & 23.0 & 22.0 & 22.5 \\
\hline 09-01-00 & 10.4 & 9.4 & 9.9 & nd & nd & 8.0 & 7.3 & 176 & 175 & 175 & 23.0 & 22.5 & 23.0 \\
\hline $09-02-00$ & 10.2 & 9.3 & 9.7 & .06 & -.16 & 8.1 & 7.2 & 177 & 175 & 176 & 24.0 & 23.0 & 23.5 \\
\hline 09-03-00 & 10.0 & 9.0 & 9.4 & nd & -.03 & 8.0 & 6.9 & 179 & 175 & 177 & 24.0 & 23.0 & 23.5 \\
\hline 09-04-00 & 11.1 & 8.8 & 9.8 & nd & -.11 & 8.9 & 6.9 & 179 & 178 & 179 & 25.0 & 23.0 & 24.0 \\
\hline 09-05-00 & 11.4 & 10.7 & 11.1 & .15 & -.13 & 9.0 & 8.4 & 179 & 177 & 178 & 24.0 & 22.5 & 23.5 \\
\hline 09-06-00 & 11.6 & 10.3 & 11.0 & .11 & -.10 & 8.8 & 7.8 & 178 & 176 & 177 & 23.0 & 21.5 & 22.0 \\
\hline 09-07-00 & 10.9 & 9.6 & 10.3 & .05 & -.10 & 7.9 & 7.1 & 179 & 176 & 177 & 21.5 & 20.0 & 21.0 \\
\hline 09-08-00 & 10.7 & 8.8 & 10.2 & .22 & -.11 & 7.7 & 7.0 & 180 & 177 & 178 & 20.5 & 20.0 & 20.5 \\
\hline 09-09-00 & 11.3 & 8.9 & 10.5 & .15 & -.04 & 8.9 & 7.2 & 181 & 178 & 179 & 22.0 & 20.0 & 21.0 \\
\hline $09-10-00$ & 10.9 & 8.6 & 10.1 & nd & -.08 & 8.8 & 7.9 & 183 & 179 & 181 & 22.5 & 21.0 & 21.5 \\
\hline $09-11-00$ & 10.5 & 9.4 & 9.9 & nd & nd & 8.3 & 7.0 & 186 & 181 & 183 & 21.5 & 20.5 & 21.0 \\
\hline $09-12-00$ & 10.1 & 8.2 & 9.3 & nd & nd & 8.1 & 6.9 & 187 & 182 & 184 & 21.5 & 21.0 & 21.0 \\
\hline 09-13-00 & 10.6 & 7.9 & 9.5 & .15 & nd & 9.1 & 6.8 & 186 & 182 & 184 & 23.5 & 21.0 & 22.5 \\
\hline $09-14-00$ & 9.8 & 8.6 & 9.2 & nd & nd & 8.8 & 7.7 & 187 & 184 & 185 & 22.5 & 21.5 & 22.0 \\
\hline $09-15-00$ & 9.8 & 8.6 & 9.1 & nd & nd & 9.0 & 8.0 & 186 & 181 & 183 & 22.0 & 21.5 & 21.5 \\
\hline 09-16-00 & 10.1 & 8.9 & 9.7 & .11 & -.04 & 9.2 & 8.7 & 186 & 182 & 184 & 21.5 & 21.0 & 21.5 \\
\hline $09-17-00$ & 9.7 & 9.1 & 9.4 & nd & nd & 9.0 & 8.8 & 186 & 182 & 184 & 21.0 & 20.0 & 20.5 \\
\hline 09-18-00 & 9.6 & 8.6 & 9.0 & nd & nd & 9.0 & 8.2 & 188 & 182 & 185 & 20.5 & 19.5 & 20.0 \\
\hline 09-19-00 & 9.4 & 8.2 & 8.7 & .20 & -.07 & -- & 7.9 & 187 & 173 & 180 & 19.5 & 19.0 & 19.5 \\
\hline 09-20-00 & 9.6 & 8.6 & 9.1 & nd & nd & -- & -- & 183 & 176 & 178 & 22.0 & 19.5 & 20.5 \\
\hline $09-21-00$ & 9.2 & 8.6 & 8.9 & nd & -.01 & -- & -- & 179 & 176 & 178 & 21.5 & 20.0 & 20.5 \\
\hline $09-22-00$ & 9.8 & 9.1 & 9.4 & .10 & nd & -- & 9.4 & 182 & 178 & 180 & 21.0 & 20.5 & 20.5 \\
\hline $09-23-00$ & 9.8 & 9.1 & 9.4 & .24 & -.05 & 9.5 & 9.0 & 180 & 178 & 179 & 20.5 & 19.5 & 20.0 \\
\hline $09-24-00$ & 9.4 & 8.9 & 9.2 & .04 & -.07 & 9.4 & 8.8 & 180 & 178 & 179 & 20.0 & 19.5 & 19.5 \\
\hline $09-25-00$ & 10.0 & 9.2 & 9.6 & .13 & -.06 & 9.5 & 9.0 & 180 & 178 & 179 & 19.5 & 19.0 & 19.0 \\
\hline $09-26-00$ & 10.1 & 9.7 & 9.9 & .05 & nd & 9.4 & 9.2 & 180 & 177 & 178 & 19.0 & 17.5 & 18.0 \\
\hline $09-27-00$ & 10.1 & 9.2 & 9.8 & nd & -.08 & 9.4 & 8.7 & 180 & 177 & 178 & 17.5 & 16.5 & 17.0 \\
\hline $09-28-00$ & 10.6 & 9.2 & 10.0 & .01 & -.10 & 9.5 & 8.4 & 181 & 179 & 180 & 17.0 & 16.0 & 16.5 \\
\hline 09-29-00 & 10.7 & 9.8 & 10.2 & nd & -.03 & 9.5 & 9.2 & 182 & 179 & 181 & 16.5 & 15.5 & 16.0 \\
\hline $09-30-00$ & 10.7 & 10.1 & 10.4 & nd & -.04 & 9.3 & 8.6 & 187 & 181 & 183 & 15.5 & 15.0 & 15.0 \\
\hline $10-01-00$ & 11.0 & 10.2 & 10.5 & nd & -.06 & 9.2 & 8.7 & 187 & 185 & 185 & 15.0 & 14.5 & 15.0 \\
\hline $10-02-00$ & 11.4 & 10.5 & 10.8 & .19 & -.10 & 9.5 & 8.8 & 187 & 185 & 186 & 16.5 & 15.0 & 15.5 \\
\hline $10-03-00$ & 11.3 & 10.4 & 10.8 & nd & -.11 & 9.7 & 9.0 & 188 & 186 & 187 & 16.5 & 15.5 & 16.0 \\
\hline $10-04-00$ & 11.0 & 10.2 & 10.5 & nd & nd & 9.5 & 8.3 & 186 & 174 & 179 & 16.5 & 15.5 & 16.0 \\
\hline $10-05-00$ & 11.3 & 10.3 & 10.9 & .12 & -.04 & 9.5 & 9.0 & 174 & 169 & 173 & 16.5 & 16.0 & 16.0 \\
\hline
\end{tabular}


Appendix 1. Continuous water-quality monitor data and estimated maximum rates of instream metabolic processes at station 01124151, Quinebaug River at West Thompson, Conn.-Continued

[mg/L, milligrams per liter; $\mathrm{P}_{\max }$ (maximum rate of productivity) and $\mathrm{R}_{\max }$ (maximum rate of respiration) in grams of oxygen per cubic meter per hour $\left(\mathrm{g} \mathrm{O}_{2} / \mathrm{m}^{3} / \mathrm{hr}\right.$ ) estimated from diel changes in dissolved oxygen concentrations; $\mu \mathrm{S} / \mathrm{cm}$, microsiemens per centimeter at 25 degrees Celsius; --, data not available due to partial record; nd, not determined due to equipment malfunction or changes in dissolved oxygen concentration that result from rapid changes in streamflow]

\begin{tabular}{|c|c|c|c|c|c|c|c|c|c|c|c|c|c|}
\hline \multirow{2}{*}{ Date } & \multicolumn{3}{|c|}{$\begin{array}{l}\text { Dissolved oxygen } \\
\text { (mg/L) }\end{array}$} & \multicolumn{2}{|c|}{$\begin{array}{l}\text { Productivity/ } \\
\text { respiration }\end{array}$} & \multicolumn{2}{|c|}{$\begin{array}{c}\mathrm{pH} \\
\text { (standard units) }\end{array}$} & \multicolumn{3}{|c|}{$\begin{array}{l}\text { Specific conductance } \\
(\mu \mathrm{S} / \mathrm{cm})\end{array}$} & \multicolumn{3}{|c|}{$\begin{array}{l}\text { Water temperature } \\
\text { (degrees Celsius) }\end{array}$} \\
\hline & Max & Min & Mean & Pmax & $R \max$ & Max & Min & Max & Min & Mean & $\operatorname{Max}$ & Min & Mean \\
\hline 10-06-00 & 11.6 & 10.6 & 11.1 & .10 & -.05 & 9.5 & 9.2 & 172 & 168 & 170 & 16.0 & 16.0 & 16.0 \\
\hline $10-07-00$ & 11.6 & 11.0 & 11.3 & .09 & -.05 & 9.4 & 9.1 & 172 & 168 & 170 & 16.0 & 15.5 & 16.0 \\
\hline $10-08-00$ & 11.7 & 11.1 & 11.3 & .06 & -.07 & 9.4 & 9.1 & 173 & 168 & 171 & 15.5 & 15.0 & 15.5 \\
\hline $10-09-00$ & 11.6 & 10.9 & 11.2 & .07 & -.04 & 9.3 & 8.4 & 178 & 169 & 173 & 15.0 & 13.0 & 14.0 \\
\hline $10-10-00$ & 11.9 & 8.7 & 10.8 & nd & -.05 & 8.4 & 7.9 & 189 & 178 & 185 & 13.0 & 7.0 & 12.5 \\
\hline $10-11-00$ & 11.2 & 10.8 & 11.0 & .03 & -.03 & 8.4 & 7.7 & 192 & 189 & 191 & 12.5 & 12.0 & 12.0 \\
\hline $10-12-00$ & 11.4 & 10.6 & 11.0 & .02 & -.08 & 8.1 & 7.6 & 198 & 192 & 196 & 12.5 & 11.5 & 12.0 \\
\hline $10-13-00$ & 11.4 & 10.6 & 11.0 & .01 & -.06 & 8.2 & 7.5 & 200 & 197 & 199 & 12.5 & 11.5 & 12.0 \\
\hline $10-14-00$ & 11.1 & 10.5 & 10.8 & nd & -.07 & 7.7 & 7.3 & 203 & 200 & 201 & 12.5 & 12.0 & 12.5 \\
\hline $10-15-00$ & 11.2 & 10.5 & 10.8 & nd & nd & 8.1 & 7.4 & 203 & 202 & 203 & 14.0 & 12.5 & 13.0 \\
\hline $10-16-00$ & 11.6 & 10.3 & 11.0 & nd & nd & 8.3 & 7.6 & 205 & 202 & 204 & 14.0 & 13.0 & 13.5 \\
\hline $10-17-00$ & 11.3 & 10.2 & 10.8 & nd & -.03 & 8.2 & 7.6 & 207 & 205 & 206 & 15.0 & 12.5 & 13.0 \\
\hline $10-18-00$ & 10.4 & 10.0 & 10.2 & nd & nd & 7.6 & 7.3 & 207 & 206 & 207 & 13.0 & 12.5 & 12.5 \\
\hline $10-19-00$ & 11.7 & 9.5 & 10.1 & .02 & nd & 7.4 & 5.9 & 210 & 207 & 209 & 15.0 & 6.5 & 12.0 \\
\hline $10-20-00$ & 10.1 & 9.8 & 9.9 & .03 & nd & 7.3 & 7.2 & 210 & 208 & 209 & 13.0 & 12.0 & 12.5 \\
\hline $10-21-00$ & 9.9 & 9.6 & 9.7 & .03 & nd & 7.3 & 7.1 & 209 & 207 & 207 & 13.0 & 12.0 & 12.5 \\
\hline $10-22-00$ & 10.2 & 9.6 & 10.0 & nd & nd & 7.3 & 7.2 & 207 & 206 & 207 & 13.0 & 12.5 & 13.0 \\
\hline $10-23-00$ & 10.3 & 10.0 & 10.1 & nd & nd & 7.3 & 7.2 & 207 & 205 & 206 & 12.5 & 12.0 & 12.0 \\
\hline $10-24-00$ & 10.3 & 9.9 & 10.1 & nd & -.02 & 7.3 & 7.2 & 206 & 204 & 205 & 12.0 & 11.5 & 12.0 \\
\hline $10-25-00$ & 10.6 & -- & -- & nd & nd & 7.4 & 7.2 & 205 & 204 & 205 & 13.0 & 11.5 & 12.0 \\
\hline $10-26-00$ & 10.4 & 7.0 & 9.1 & nd & nd & 7.5 & 7.2 & 208 & 197 & 203 & 12.5 & 12.0 & 12.0 \\
\hline $10-27-00$ & 7.5 & 6.1 & 6.7 & nd & nd & 7.6 & 7.2 & 204 & 203 & 203 & 12.5 & 12.0 & 12.5 \\
\hline $10-28-00$ & 9.5 & 7.4 & 8.7 & nd & nd & 7.7 & 7.3 & 203 & 202 & 203 & 13.0 & 11.5 & 12.5 \\
\hline $10-29-00$ & 9.2 & 8.2 & 8.6 & nd & nd & 7.5 & 7.3 & 203 & 201 & 202 & 11.5 & 9.5 & 10.5 \\
\hline $10-30-00$ & 9.3 & 8.0 & 8.8 & nd & nd & 7.4 & 7.3 & 202 & 201 & 202 & 9.5 & 8.0 & 9.0 \\
\hline $10-31-00$ & 12.4 & 8.3 & 10.2 & nd & nd & 7.7 & 7.3 & 202 & 198 & 200 & 9.0 & 7.5 & 8.0 \\
\hline $11-01-00$ & 11.7 & 11.5 & 11.6 & nd & nd & 7.7 & 7.5 & 198 & 197 & 198 & 8.0 & 7.5 & 7.5 \\
\hline $11-02-00$ & 11.7 & 11.6 & 11.6 & nd & nd & 7.8 & 7.6 & 198 & 196 & 197 & 8.5 & 7.5 & 8.0 \\
\hline $11-03-00$ & 11.8 & 11.6 & 11.6 & nd & nd & 8.0 & 7.7 & 197 & 194 & 196 & 9.0 & 8.0 & 8.5 \\
\hline $11-04-00$ & 11.7 & 11.5 & 11.6 & nd & nd & 7.8 & 7.6 & 195 & 192 & 194 & 9.0 & 8.5 & 8.5 \\
\hline $11-05-00$ & 11.6 & 11.5 & 11.6 & nd & -.01 & 7.7 & 7.6 & 193 & 190 & 192 & 8.5 & 8.5 & 8.5 \\
\hline $11-06-00$ & 11.7 & 11.6 & 11.7 & nd & -.01 & 7.7 & 7.5 & 190 & 185 & 188 & 8.5 & 8.0 & 8.5 \\
\hline $11-07-00$ & 11.8 & 11.6 & 11.7 & nd & nd & 7.7 & 7.5 & 185 & 181 & 183 & 9.0 & 8.0 & 8.5 \\
\hline $11-08-00$ & 11.8 & 11.7 & 11.7 & nd & nd & 7.9 & 7.5 & 182 & 178 & 181 & 9.0 & 8.5 & 9.0 \\
\hline $11-09-00$ & 11.9 & 11.7 & 11.7 & nd & nd & 8.1 & 7.6 & 179 & 174 & 177 & 9.5 & 8.5 & 9.0 \\
\hline $11-10-00$ & 11.7 & 11.6 & 11.7 & nd & nd & 7.6 & 7.5 & 175 & 168 & 172 & 9.0 & 9.0 & 9.0 \\
\hline $11-11-00$ & 11.7 & 11.6 & 11.6 & nd & -.02 & 7.5 & 7.3 & 168 & 157 & 162 & 9.5 & 9.0 & 9.0 \\
\hline $11-12-00$ & 11.6 & 11.5 & 11.6 & nd & nd & 7.4 & 7.3 & 158 & 152 & 156 & 9.5 & 9.0 & 9.5 \\
\hline $11-13-00$ & 11.7 & 11.6 & 11.7 & nd & nd & 7.4 & 7.3 & 160 & 156 & 157 & 9.0 & 9.0 & 9.0 \\
\hline $11-14-00$ & 11.6 & 11.4 & 11.5 & nd & nd & 7.3 & 7.2 & 158 & 154 & 156 & 9.0 & 9.0 & 9.0 \\
\hline $11-15-00$ & 11.9 & 11.5 & 11.7 & nd & -.01 & 7.3 & 7.2 & 157 & 154 & 156 & 9.0 & 8.0 & 8.5 \\
\hline $11-16-00$ & 12.1 & 11.9 & 12.0 & nd & -.01 & 7.3 & 7.3 & 160 & 157 & 158 & 8.0 & 8.0 & 8.0 \\
\hline $11-17-00$ & 12.1 & 11.2 & 11.6 & nd & nd & 7.3 & 7.3 & 158 & 156 & 158 & 8.0 & 7.5 & 8.0 \\
\hline
\end{tabular}


Appendix 1. Continuous water-quality monitor data and estimated maximum rates of instream metabolic processes at station 01124151 , Quinebaug River at West Thompson, Conn.-Continued

[mg/L, milligrams per liter; $\mathrm{P}_{\max }$ (maximum rate of productivity) and $\mathrm{R}_{\max }$ (maximum rate of respiration) in grams of oxygen per cubic meter per hour $\left(\mathrm{g} \mathrm{O}_{2} / \mathrm{m}^{3} / \mathrm{hr}\right.$ ) estimated from diel changes in dissolved oxygen concentrations; $\mu \mathrm{S} / \mathrm{cm}$, microsiemens per centimeter at 25 degrees Celsius; --, data not available due to partial record; nd, not determined due to equipment malfunction or changes in dissolved oxygen concentration that result from rapid changes in streamflow]

\begin{tabular}{|c|c|c|c|c|c|c|c|c|c|c|c|c|c|}
\hline \multirow{2}{*}{ Date } & \multicolumn{3}{|c|}{$\begin{array}{l}\text { Dissolved oxygen } \\
\text { (mg/L) }\end{array}$} & \multicolumn{2}{|c|}{$\begin{array}{l}\text { Productivity/ } \\
\text { respiration }\end{array}$} & \multicolumn{2}{|c|}{$\begin{array}{c}\mathrm{pH} \\
\text { (standard units) }\end{array}$} & \multicolumn{3}{|c|}{$\begin{array}{l}\text { Specific conductance } \\
(\mu \mathrm{S} / \mathrm{cm})\end{array}$} & \multicolumn{3}{|c|}{$\begin{array}{l}\text { Water temperature } \\
\text { (degrees Celsius) }\end{array}$} \\
\hline & Max & Min & Mean & Pmax & Rmax & Max & Min & Max & Min & Mean & Max & Min & Mean \\
\hline $11-18-00$ & 11.5 & 11.3 & 11.5 & nd & nd & 7.3 & 7.3 & 158 & 155 & 157 & 7.5 & 7.0 & 7.0 \\
\hline $11-19-00$ & 11.6 & 11.4 & 11.6 & nd & -.02 & 7.3 & 7.2 & 156 & 154 & 154 & 7.0 & 6.5 & 7.0 \\
\hline $11-20-00$ & 11.8 & 11.6 & 11.7 & nd & nd & 7.3 & 7.2 & 154 & 153 & 153 & 6.5 & 6.0 & 6.0 \\
\hline $11-21-00$ & 11.8 & 11.6 & 11.8 & nd & nd & 7.4 & 7.2 & 153 & 153 & 153 & 6.0 & 5.5 & 6.0 \\
\hline $11-22-00$ & 12.2 & 11.8 & 12.0 & nd & nd & 7.4 & 7.3 & 153 & 152 & 152 & 5.5 & 4.0 & 4.5 \\
\hline $11-23-00$ & 12.7 & 12.2 & 12.5 & nd & nd & 7.3 & 7.3 & 153 & 152 & 153 & 4.0 & 3.0 & 3.5 \\
\hline $11-24-00$ & 12.9 & 12.7 & 12.8 & nd & nd & 7.3 & 7.3 & 154 & 153 & 154 & 3.0 & 2.5 & 2.5 \\
\hline $11-25-00$ & 13.0 & 12.8 & 12.9 & nd & nd & 7.3 & 7.3 & 156 & 154 & 155 & 3.0 & 3.0 & 3.0 \\
\hline $11-26-00$ & 12.8 & 12.5 & 12.7 & nd & nd & 7.3 & 7.3 & 156 & 153 & 155 & 3.0 & 3.0 & 3.0 \\
\hline $11-27-00$ & 13.0 & 12.6 & 12.9 & nd & nd & 7.3 & 7.2 & 158 & 155 & 156 & 3.0 & 3.0 & 3.0 \\
\hline $11-28-00$ & 13.2 & 12.9 & 13.0 & nd & nd & 7.3 & 7.2 & 159 & 156 & 158 & 3.5 & 3.0 & 3.0 \\
\hline $11-29-00$ & 13.1 & 12.7 & 12.9 & nd & nd & 7.2 & 7.1 & 159 & 156 & 157 & 4.0 & 3.0 & 3.5 \\
\hline $11-30-00$ & 12.8 & 12.6 & 12.7 & nd & nd & 7.2 & 7.1 & 162 & 155 & 158 & 3.5 & 3.5 & 3.5 \\
\hline $12-01-00$ & 12.9 & 12.7 & 12.8 & nd & nd & 7.1 & 7.1 & 171 & 158 & 167 & 3.5 & 3.0 & 3.5 \\
\hline $12-02-00$ & 13.2 & 12.9 & 13.0 & nd & nd & 7.1 & 7.1 & 181 & 170 & 176 & 3.0 & 2.5 & 3.0 \\
\hline $12-03-00$ & 13.2 & 13.1 & 13.2 & nd & nd & 7.1 & 7.1 & 191 & 181 & 188 & 2.5 & 2.0 & 2.5 \\
\hline $12-04-00$ & 13.1 & 13.0 & 13.1 & nd & nd & 7.2 & 7.1 & 194 & 190 & 193 & 3.0 & 2.5 & 3.0 \\
\hline $12-05-00$ & 13.0 & -- & -- & nd & nd & -- & 7.1 & -- & 193 & -- & -- & 3.0 & -- \\
\hline $05-03-01$ & 12.2 & 10.8 & 12.3 & nd & nd & 7.6 & -- & 172 & -- & -- & 17.5 & -- & -- \\
\hline $05-04-01$ & 12.5 & 10.0 & 11.0 & nd & nd & 7.9 & 6.8 & 178 & 170 & 173 & 21.0 & 17.0 & 19.0 \\
\hline $05-05-01$ & 11.0 & 10.0 & 10.4 & nd & nd & 7.8 & 7.0 & 190 & 173 & 184 & 21.5 & 19.0 & 20.5 \\
\hline $05-06-01$ & 11.3 & 10.7 & 10.9 & nd & nd & 7.7 & 6.9 & 191 & 187 & 190 & 20.0 & 19.0 & 19.5 \\
\hline 05-07-01 & 12.5 & 11.2 & 12.1 & nd & nd & 7.2 & 6.7 & 205 & 191 & 196 & 19.0 & 17.0 & 17.5 \\
\hline $05-08-01$ & 12.7 & 12.4 & 12.5 & nd & nd & 7.2 & 6.7 & 208 & 197 & 202 & 17.0 & 16.5 & 16.5 \\
\hline 05-09-01 & 12.5 & 12.2 & -- & nd & nd & 7.6 & 6.6 & 207 & 201 & 203 & 18.0 & 16.5 & 17.0 \\
\hline $05-10-01$ & -- & 11.8 & -- & nd & nd & 8.0 & 6.7 & 209 & 204 & 206 & 20.5 & 17.0 & 19.0 \\
\hline $05-11-01$ & -- & -- & -- & nd & nd & 7.7 & 6.7 & 209 & 206 & 208 & 20.5 & 18.5 & 19.5 \\
\hline $05-12-01$ & -- & -- & -- & nd & nd & 7.0 & 6.5 & 214 & 208 & 211 & 21.0 & 18.5 & 19.5 \\
\hline $05-13-01$ & -- & -- & -- & nd & nd & 7.2 & 7.0 & 216 & 213 & 215 & 21.0 & 20.0 & 2.05 \\
\hline $05-14-01$ & -- & -- & -- & nd & nd & 7.2 & 6.8 & 217 & 215 & 216 & 20.5 & 19.0 & 19.5 \\
\hline $05-15-01$ & -- & -- & -- & nd & nd & 7.0 & 6.8 & 218 & 216 & 217 & 19.0 & 17.0 & 18.0 \\
\hline $05-16-01$ & -- & -- & -- & nd & nd & 6.9 & 6.8 & 218 & 217 & 218 & 17.0 & 16.0 & 16.5 \\
\hline $05-17-01$ & -- & -- & -- & nd & nd & 6.8 & 6.6 & 222 & 218 & 219 & 16.0 & 15.5 & 16.0 \\
\hline $05-18-01$ & -- & -- & -- & nd & nd & 6.8 & 6.1 & 227 & 219 & 223 & 15.5 & 15.0 & 15.0 \\
\hline $05-19-01$ & -- & -- & -- & nd & nd & 7.0 & 6.7 & 222 & 220 & 221 & 17.5 & 15.0 & 16.0 \\
\hline $05-20-01$ & -- & -- & -- & nd & nd & 6.8 & 6.6 & 222 & 220 & 221 & 17.0 & 16.0 & 16.5 \\
\hline $05-21-01$ & -- & -- & -- & nd & nd & 6.8 & 6.5 & 222 & 220 & 221 & 17.5 & 16.0 & 16.5 \\
\hline $05-22-01$ & -- & -- & -- & nd & nd & 6.8 & 6.6 & 221 & 220 & 220 & 18.0 & 17.0 & 18.0 \\
\hline $05-23-01$ & -- & -- & -- & nd & nd & 6.7 & 6.4 & 221 & 218 & 219 & 18.0 & 17.0 & 17.5 \\
\hline $05-24-01$ & -- & -- & -- & nd & nd & 6.7 & 6.5 & 218 & 214 & 216 & 17.0 & 16.5 & 16.5 \\
\hline $05-25-01$ & -- & -- & -- & nd & nd & 6.7 & 6.5 & 215 & 197 & 210 & 17.0 & 15.5 & 16.0 \\
\hline $05-26-01$ & -- & -- & -- & nd & nd & 6.7 & 6.5 & 204 & 195 & 200 & 16.5 & 15.5 & 16.0 \\
\hline $05-27-01$ & -- & -- & -- & nd & nd & 6.7 & 6.5 & 200 & 191 & 196 & 17.5 & 16.0 & 16.5 \\
\hline
\end{tabular}


Appendix 1. Continuous water-quality monitor data and estimated maximum rates of instream metabolic processes at station 01124151 , Quinebaug River at West Thompson, Conn.-Continued

$\left[\mathrm{mg} / \mathrm{L}\right.$, milligrams per liter; $\mathrm{P}_{\max }$ (maximum rate of productivity) and $\mathrm{R}_{\max }$ (maximum rate of respiration) in grams of oxygen per cubic meter per hour $\left(\mathrm{g} \mathrm{O}_{2} / \mathrm{m}^{3} / \mathrm{hr}\right.$ ) estimated from diel changes in dissolved oxygen concentrations; $\mu \mathrm{S} / \mathrm{cm}$, microsiemens per centimeter at 25 degrees Celsius; --, data not available due to partial record; nd, not determined due to equipment malfunction or changes in dissolved oxygen concentration that result from rapid changes in streamflow]

\begin{tabular}{|c|c|c|c|c|c|c|c|c|c|c|c|c|c|}
\hline \multirow{2}{*}{ Date } & \multicolumn{3}{|c|}{$\begin{array}{l}\text { Dissolved oxygen } \\
\text { (mg/L) }\end{array}$} & \multicolumn{2}{|c|}{$\begin{array}{l}\text { Productivity/ } \\
\text { respiration }\end{array}$} & \multicolumn{2}{|c|}{$\begin{array}{c}\mathrm{pH} \\
\text { (standard units) }\end{array}$} & \multicolumn{3}{|c|}{$\begin{array}{l}\text { Specific conductance } \\
\qquad(\mu \mathrm{S} / \mathrm{cm})\end{array}$} & \multicolumn{3}{|c|}{$\begin{array}{l}\text { Water temperature } \\
\text { (degrees Celsius) }\end{array}$} \\
\hline & Max & Min & Mean & Pmax & $R \max$ & Max & Min & Max & Min & Mean & Max & Min & Mean \\
\hline $05-28-01$ & -- & -- & -- & nd & nd & 6.5 & 6.4 & 191 & 178 & 183 & 17.5 & 16.5 & 17.0 \\
\hline $05-29-01$ & -- & -- & -- & nd & nd & 6.6 & 6.4 & 184 & 173 & 179 & 18.0 & 17.0 & 17.5 \\
\hline $05-30-01$ & -- & -- & -- & nd & nd & 6.7 & 6.4 & 177 & 173 & 175 & 18.5 & 17.5 & 18.0 \\
\hline $05-31-01$ & -- & -- & -- & nd & nd & 6.7 & 6.5 & 181 & 173 & 175 & 17.5 & 17.0 & 17.0 \\
\hline 06-01-01 & -- & -- & -- & nd & nd & 6.6 & 6.4 & 200 & 179 & 184 & 17.0 & 16.0 & 16.5 \\
\hline $06-02-01$ & -- & -- & -- & nd & nd & 6.6 & 6.4 & 196 & 186 & 189 & 17.0 & 16.5 & 16.5 \\
\hline 06-03-01 & -- & -- & -- & nd & nd & 6.5 & 6.4 & 192 & 170 & 181 & 17.5 & 16.5 & 17.0 \\
\hline 06-04-01 & -- & -- & -- & nd & nd & 6.7 & 6.4 & 178 & 169 & 173 & 18.0 & 17.0 & 17.5 \\
\hline 06-05-01 & -- & -- & -- & nd & nd & 6.6 & 6.4 & 171 & 169 & 170 & 19.0 & 17.5 & 18.0 \\
\hline 06-06-01 & -- & -- & -- & nd & nd & 6.6 & 6.4 & 171 & 169 & 171 & 19.5 & 18.0 & 18.5 \\
\hline 06-07-01 & -- & -- & -- & nd & nd & 6.6 & 6.3 & 176 & 167 & 172 & 20.0 & 18.5 & 19.0 \\
\hline 06-08-01 & -- & -- & -- & nd & nd & 6.7 & 6.4 & 176 & 170 & 173 & 21.5 & 18.0 & 19.5 \\
\hline 06-09-01 & -- & -- & -- & nd & nd & 6.6 & 6.3 & 174 & 168 & 171 & 20.5 & 19.0 & 19.5 \\
\hline $06-21-01$ & -- & -- & -- & nd & nd & 6.8 & -- & -- & 155 & -- & 25.0 & 24.0 & -- \\
\hline $06-22-01$ & -- & -- & -- & nd & nd & 6.6 & 6.4 & 155 & 148 & 151 & 24.0 & 22.5 & 23.0 \\
\hline $06-23-01$ & -- & -- & -- & nd & nd & 6.6 & 6.4 & 150 & 148 & 149 & 23.0 & 22.0 & 22.5 \\
\hline $06-24-01$ & -- & -- & -- & nd & nd & 6.7 & 6.5 & 150 & 148 & 149 & 23.5 & 23.0 & 23.5 \\
\hline $06-25-01$ & -- & -- & -- & nd & nd & 6.7 & 6.5 & 150 & 148 & 149 & 24.0 & 23.0 & 23.5 \\
\hline $06-26-01$ & -- & -- & -- & nd & nd & 6.6 & 6.4 & 152 & 149 & 150 & 23.5 & 23.0 & 23.0 \\
\hline $06-27-01$ & -- & -- & -- & nd & nd & 7.0 & 6.4 & 157 & 150 & 152 & 26.5 & 23.0 & 24.5 \\
\hline $06-28-01$ & -- & -- & -- & nd & nd & 7.1 & 6.4 & 163 & 155 & 157 & 27.5 & 24.0 & 26.0 \\
\hline 06-29-01 & -- & -- & -- & nd & nd & 6.8 & 6.4 & 165 & 158 & 161 & 26.5 & 24.5 & 25.5 \\
\hline 06-30-01 & -- & -- & -- & nd & nd & 6.8 & 6.5 & 166 & 160 & 162 & 26.5 & 24.5 & 25.0 \\
\hline 07-01-01 & -- & -- & -- & nd & nd & 6.8 & 6.5 & 175 & 161 & 165 & 26.0 & 24.5 & 25.5 \\
\hline $07-02-01$ & -- & -- & -- & nd & nd & 7.0 & 6.7 & 174 & 166 & 169 & 26.0 & 24.5 & 25.0 \\
\hline 07-03-01 & -- & -- & -- & nd & nd & 6.9 & 6.6 & 194 & 173 & 180 & 24.5 & 23.5 & 24.0 \\
\hline 07-04-01 & -- & -- & -- & nd & nd & 6.8 & 6.6 & 200 & 184 & 188 & 23.5 & 23.0 & 23.0 \\
\hline $07-05-01$ & -- & -- & -- & nd & nd & -- & 6.6 & -- & 184 & -- & 23.5 & -- & -- \\
\hline
\end{tabular}


36 Nutrient Enrichment, Phytoplankton Algal Growth, and Rates of Metabolism in the Quinebaug River Basin, Conn.

Appendix 2 
Appendix 2. Continuous water-quality monitor data and estimated maximum rates of instream metabolic processes at station 01125520 , Quinebaug River at Cotton Bridge Road near Pomfret Landing, Conn.

[mg/L, milligrams per liter; $\mathrm{P}_{\max }$ (maximum rate of productivity) and $\mathrm{R}_{\max }$ (maximum rate of respiration) in grams of oxygen per cubic meter per hour $\left(\mathrm{g} \mathrm{O}_{2} / \mathrm{m}^{3} / \mathrm{hr}\right.$ ) estimated from diel changes in dissolved oxygen concentrations; $\mu \mathrm{S} / \mathrm{cm}$, microsiemens per centimeter at 25 degrees Celsius; --, data not available due to partial record; nd, not determined due to equipment malfunction or changes in dissolved oxygen concentration that result from rapid changes in streamflow]

\begin{tabular}{|c|c|c|c|c|c|c|c|c|c|c|c|c|c|}
\hline \multirow[t]{2}{*}{ Date } & \multicolumn{3}{|c|}{$\begin{array}{l}\text { Dissolved oxygen } \\
\text { (mg/L) }\end{array}$} & \multicolumn{2}{|c|}{$\begin{array}{l}\text { Productivity/ } \\
\text { respiration }\end{array}$} & \multicolumn{2}{|c|}{$\begin{array}{c}\mathrm{pH} \\
\text { (standard units) }\end{array}$} & \multicolumn{3}{|c|}{$\begin{array}{l}\text { Specific conductance } \\
(\mu \mathrm{S} / \mathrm{cm})\end{array}$} & \multicolumn{3}{|c|}{$\begin{array}{l}\text { Water temperature } \\
\text { (degrees Celsius) }\end{array}$} \\
\hline & Max & Min & Mean & Pmax & $R \max$ & Max & Min & Max & Min & Mean & Max & Min & Mean \\
\hline $05-23-00$ & -- & 10.3 & -- & nd & nd & -- & -- & 141 & -- & -- & 15.5 & -- & -- \\
\hline $05-24-00$ & 10.9 & 10.0 & 10.5 & 0.08 & -0.14 & 6.9 & 6.8 & 141 & 134 & 138 & 16.0 & 14.0 & 15.0 \\
\hline $05-25-00$ & 10.6 & 9.6 & 10.1 & .11 & -.14 & 7.0 & 6.8 & 139 & 134 & 136 & 18.0 & 15.5 & 16.5 \\
\hline $05-26-00$ & 10.6 & 9.5 & 10.0 & .16 & -.16 & 7.0 & 6.8 & 134 & 131 & 133 & 18.5 & 16.5 & 17.5 \\
\hline $05-27-00$ & 10.4 & 9.2 & 9.8 & .16 & -.15 & 7.0 & 6.7 & 136 & 132 & 134 & 19.0 & 17.0 & 18.0 \\
\hline $05-28-00$ & 10.2 & 9.2 & 9.6 & .14 & -.13 & 6.9 & 6.7 & 138 & 135 & 136 & 18.0 & 17.0 & 17.5 \\
\hline $05-29-00$ & 10.4 & 9.3 & 9.8 & .13 & -.17 & 6.9 & 6.7 & 139 & 136 & 138 & 18.0 & 16.5 & 17.0 \\
\hline $05.30-00$ & 10.8 & 9.3 & 9.9 & .16 & -.25 & 6.9 & 6.7 & 142 & 137 & 140 & 18.0 & 16.0 & 16.5 \\
\hline $05-31-00$ & 10.8 & 8.6 & 9.8 & .19 & -.41 & 6.9 & 6.6 & 147 & 138 & 141 & 19.5 & 15.5 & 17.0 \\
\hline $06-01-00$ & 10.7 & 8.3 & 9.5 & .23 & -.32 & 7.2 & 6.6 & 147 & 140 & 143 & 21.0 & 16.5 & 18.5 \\
\hline $06-02-00$ & 10.1 & 7.4 & 8.8 & .27 & -.46 & 7.6 & 6.6 & 147 & 141 & 145 & 23.0 & 19.0 & 20.5 \\
\hline 06-03-00 & 9.8 & 7.2 & 8.4 & .25 & -.34 & 7.3 & 6.6 & 152 & 141 & 146 & 22.5 & 19.5 & 21.0 \\
\hline $06-04-00$ & 9.5 & 7.4 & 8.3 & .27 & -.29 & 7.6 & 6.7 & 152 & 146 & 149 & 23.0 & 19.5 & 21.0 \\
\hline $06-05-00$ & 9.1 & 7.5 & 8.1 & .26 & -.20 & 7.2 & 6.7 & 157 & 151 & 154 & 20.5 & 19.5 & 20.0 \\
\hline 06-06-00 & 8.3 & 7.5 & 8.0 & .22 & -.03 & 6.9 & 6.7 & 154 & 145 & 152 & 19.5 & 16.5 & 18.0 \\
\hline $06-07-00$ & 9.1 & 8.2 & 8.7 & nd & -.04 & 7.0 & 6.7 & 145 & 130 & 137 & 17.0 & 15.0 & 16.0 \\
\hline $06-08-00$ & 9.0 & 8.6 & 8.8 & nd & -.04 & 6.9 & 6.8 & 130 & 125 & 127 & 16.5 & 15.0 & 15.5 \\
\hline 06-09-00 & 10.8 & 8.5 & 9.3 & .02 & -.12 & 6.9 & 6.7 & 126 & 121 & 123 & 17.5 & 16.0 & 16.5 \\
\hline $06-10-00$ & 10.1 & 9.2 & 9.8 & .05 & nd & 7.0 & 6.8 & 121 & 118 & 119 & 20.0 & 17.5 & 18.5 \\
\hline $06-11-00$ & 9.4 & 8.8 & 9.1 & .04 & -.01 & 7.0 & 6.8 & 118 & 112 & 116 & 21.5 & 19.5 & 20.5 \\
\hline $06-12-00$ & 9.2 & 8.8 & 9.1 & .08 & -.07 & 6.9 & 6.8 & 118 & 114 & 116 & 20.5 & 18.0 & 19.0 \\
\hline $06-13-00$ & 9.6 & 9.1 & 9.3 & .04 & -.04 & 7.0 & 6.9 & 122 & 115 & 117 & 18.5 & 17.5 & 18.0 \\
\hline $06-14-00$ & 9.4 & 9.1 & 9.2 & .01 & -.05 & 6.9 & 6.9 & 129 & 122 & 126 & 17.5 & 17.0 & 17.0 \\
\hline $06-15-00$ & 9.1 & 8.8 & 9.0 & nd & nd & 6.9 & 6.9 & 130 & 126 & 128 & 17.0 & 16.5 & 17.0 \\
\hline $06-16-00$ & -- & -- & -- & nd & nd & 6.9 & 6.7 & 137 & 128 & 131 & 20.5 & 17.0 & 18.5 \\
\hline $06-17-00$ & -- & -- & -- & nd & nd & 7.0 & 6.8 & 133 & 129 & 131 & 22.5 & 19.0 & 20.5 \\
\hline $06-18-00$ & -- & -- & -- & nd & nd & 7.0 & 6.8 & 134 & 131 & 132 & 22.0 & 21.0 & 21.5 \\
\hline 06-19-00 & -- & -- & -- & nd & nd & 7.0 & 6.8 & 135 & 132 & 133 & 21.5 & 20.5 & 21.0 \\
\hline $06-20-00$ & -- & -- & -- & nd & nd & 7.1 & 6.8 & 136 & 133 & 135 & 22.5 & 20.0 & 21.0 \\
\hline $06-21-00$ & -- & -- & -- & nd & nd & 7.1 & 6.8 & 139 & 134 & 136 & 23.0 & 20.5 & 21.5 \\
\hline $06-22-00$ & -- & -- & -- & nd & nd & 7.2 & 6.8 & 143 & 137 & 140 & 23.5 & 21.0 & 22.0 \\
\hline $06-23-00$ & -- & -- & -- & nd & nd & 7.2 & 6.8 & 149 & 142 & 145 & 24.0 & 21.5 & 22.5 \\
\hline $06-24-00$ & -- & -- & -- & nd & nd & 7.5 & 6.8 & 151 & 144 & 146 & 25.0 & 21.5 & 23.5 \\
\hline $06-25-00$ & -- & -- & -- & nd & nd & 7.4 & 6.8 & 152 & 147 & 149 & 25.5 & 22.0 & 23.5 \\
\hline $06-26-00$ & -- & -- & -- & nd & nd & 7.4 & 6.8 & 157 & 149 & 154 & 25.0 & 22.5 & 23.5 \\
\hline $06-27-00$ & -- & -- & -- & nd & nd & 7.8 & 6.8 & 155 & 147 & 152 & 26.5 & 23.0 & 24.5 \\
\hline $06-28-00$ & 9.8 & -- & -- & nd & -.38 & 7.9 & 6.8 & 150 & 143 & 146 & 26.0 & 23.0 & 24.0 \\
\hline $06-29-00$ & 9.6 & 7.0 & 8.1 & .25 & -.38 & 7.6 & 6.8 & 150 & 142 & 146 & 24.5 & 23.0 & 23.5 \\
\hline $06-30-00$ & 9.8 & 7.4 & 8.4 & .29 & -.32 & 7.7 & 6.8 & 158 & 147 & 151 & 25.5 & 22.0 & 23.5 \\
\hline 07-01-00 & 9.7 & 7.2 & 8.3 & .37 & -.35 & 7.9 & 6.8 & 157 & 147 & 152 & 26.0 & 21.5 & 23.5 \\
\hline $07-02-00$ & 10.1 & 7.1 & 8.3 & .39 & -.04 & 7.9 & 6.8 & 157 & 151 & 153 & 26.5 & 22.0 & 24.0 \\
\hline 07-03-00 & 10.2 & 7.0 & 8.4 & .42 & -.39 & 8.1 & 6.8 & 167 & 154 & 158 & 25.5 & 22.5 & 24.0 \\
\hline $07-04-00$ & 10.1 & 6.8 & 8.2 & .43 & -.40 & 8.0 & 6.8 & 170 & 160 & 164 & 26.0 & 23.0 & 24.5 \\
\hline $07-05-00$ & 9.9 & 6.7 & 8.2 & .43 & -.42 & 7.9 & 6.8 & 179 & 163 & 168 & 26.5 & 23.0 & 24.5 \\
\hline $07-06-00$ & 10.2 & 6.7 & 8.3 & .46 & -.43 & 8.0 & 6.8 & 180 & 164 & 171 & 26.0 & 21.5 & 24.0 \\
\hline $07-07-00$ & 10.2 & 6.7 & 8.3 & .46 & -.38 & 8.0 & 6.8 & 182 & 165 & 172 & 25.0 & 21.5 & 23.5 \\
\hline
\end{tabular}


Appendix 2. Continuous water-quality monitor data and estimated maximum rates of instream metabolic processes at station 01125520 , Quinebaug River at Cotton Bridge Road near Pomfret Landing, Conn.-Continued

[mg/L, milligrams per liter; $\mathrm{P}_{\max }$ (maximum rate of productivity) and $\mathrm{R}_{\max }$ (maximum rate of respiration) in grams of oxygen per cubic meter per hour $\left(\mathrm{g} \mathrm{O}_{2} / \mathrm{m}^{3} / \mathrm{hr}\right.$ ) estimated from diel changes in dissolved oxygen concentrations; $\mu \mathrm{S} / \mathrm{cm}$, microsiemens per centimeter at 25 degrees Celsius; --, data not available due to partial record; nd, not determined due to equipment malfunction or changes in dissolved oxygen concentration that result from rapid changes in streamflow]

\begin{tabular}{|c|c|c|c|c|c|c|c|c|c|c|c|c|c|}
\hline \multirow{2}{*}{ Date } & \multicolumn{3}{|c|}{$\begin{array}{l}\text { Dissolved oxygen } \\
\text { (mg/L) }\end{array}$} & \multicolumn{2}{|c|}{$\begin{array}{l}\text { Productivity/ } \\
\text { respiration }\end{array}$} & \multicolumn{2}{|c|}{$\begin{array}{c}\mathrm{pH} \\
\text { (standard units) }\end{array}$} & \multicolumn{3}{|c|}{$\begin{array}{l}\text { Specific conductance } \\
(\mu \mathrm{S} / \mathrm{cm})\end{array}$} & \multicolumn{3}{|c|}{$\begin{array}{l}\text { Water temperature } \\
\text { (degrees Celsius) }\end{array}$} \\
\hline & Max & Min & Mean & Pmax & Rmax & Max & Min & Max & Min & Mean & Max & Min & Mean \\
\hline $07-08-00$ & 10.5 & 6.9 & 8.5 & .47 & -.44 & 8.2 & 6.8 & 182 & 166 & 173 & 24.5 & 20.0 & 22.5 \\
\hline 07-09-00 & 10.7 & 6.9 & 8.6 & .49 & -.47 & 8.3 & 6.8 & 175 & 165 & 169 & 24.0 & 20.5 & 22.5 \\
\hline $07-10-00$ & 10.9 & 6.7 & 8.6 & .54 & -.48 & 8.6 & 6.8 & 181 & 167 & 172 & 25.5 & 22.0 & 23.5 \\
\hline $07-11-00$ & 12.0 & 6.6 & 9.2 & .70 & -.47 & 8.7 & 6.8 & 189 & 175 & 179 & 25.0 & 21.0 & 23.0 \\
\hline $07-12-00$ & 13.2 & 7.0 & 9.9 & .78 & -.58 & 8.8 & 6.8 & 201 & 183 & 193 & 24.5 & 20.5 & 23.0 \\
\hline $07-13-00$ & 13.7 & 7.0 & 10.2 & .92 & -.67 & 9.0 & 6.9 & 202 & 183 & 194 & 24.5 & 21.5 & 23.0 \\
\hline $07-14-00$ & 13.7 & 6.1 & 10.2 & .92 & -.66 & 9.1 & 6.9 & 203 & 188 & 196 & 25.0 & 22.0 & 23.5 \\
\hline $07-15-00$ & 12.1 & 6.7 & 9.4 & .70 & -.55 & 8.7 & 7.0 & 207 & 186 & 198 & 25.0 & 22.0 & 23.0 \\
\hline $07-16-00$ & 11.9 & 6.7 & 9.0 & .68 & -.63 & 8.5 & 6.8 & 189 & 162 & 175 & 25.5 & 21.5 & 23.0 \\
\hline $07-17-00$ & 11.9 & 6.0 & 8.8 & .72 & -.69 & 8.8 & 6.8 & 205 & 185 & 193 & 25.5 & 22.0 & 24.0 \\
\hline $07-18-00$ & 11.8 & 6.7 & 8.9 & .68 & -.64 & 8.8 & 6.9 & 203 & 179 & 190 & 26.0 & 22.5 & 24.5 \\
\hline 07-19-00 & 10.8 & 6.6 & 8.7 & .46 & -.48 & 8.3 & 6.9 & 202 & 182 & 192 & 24.5 & 21.5 & 22.5 \\
\hline $07-20-00$ & 12.1 & 7.2 & 9.3 & .64 & -.58 & 8.8 & 6.9 & 205 & 186 & 194 & 25.0 & 20.5 & 22.5 \\
\hline $07-21-00$ & 12.2 & 6.7 & 9.3 & .70 & -.69 & 8.9 & 6.9 & 206 & 186 & 196 & 24.5 & 20.5 & 22.5 \\
\hline $07-22-00$ & 11.9 & 5.8 & 9.2 & .64 & -.58 & 8.6 & 6.8 & 207 & 169 & 184 & 25.5 & 21.5 & 23.5 \\
\hline $07-23-00$ & 11.9 & 6.8 & 9.1 & .68 & -.57 & 8.6 & 6.9 & 209 & 191 & 200 & 25.0 & 20.5 & 23.0 \\
\hline $07-24-00$ & 12.1 & 6.3 & 9.1 & .66 & -.68 & 8.7 & 6.9 & 236 & 196 & 207 & 24.5 & 21.0 & 23.0 \\
\hline $07-25-00$ & 11.0 & 5.7 & 8.6 & .59 & -.38 & 8.1 & 6.9 & 240 & 198 & 216 & 24.5 & 22.0 & 22.5 \\
\hline $07-26-00$ & 8.9 & 6.4 & 7.7 & .26 & -.20 & 7.3 & 6.9 & 230 & 196 & 213 & 22.5 & 20.5 & 21.0 \\
\hline $07-27-00$ & 9.7 & 6.9 & 8.3 & .29 & -.32 & 7.3 & 6.9 & 216 & 176 & 195 & 20.5 & 19.5 & 20.0 \\
\hline $07-28-00$ & 9.9 & 8.2 & 9.0 & .18 & -.17 & 7.8 & 7.1 & 192 & 181 & 188 & 22.0 & 20.5 & 21.0 \\
\hline $07-29-00$ & 9.5 & 8.4 & 8.9 & .19 & -.18 & 7.4 & 7.1 & 191 & 169 & 179 & 21.5 & 20.5 & 21.p \\
\hline $07-30-00$ & 9.8 & 8.3 & 9.0 & .19 & -.23 & 7.4 & 7.0 & 169 & 165 & 167 & 21.5 & 20.0 & 20.5 \\
\hline $07-31-00$ & 9.2 & 8.2 & 8.6 & .21 & -.09 & 7.2 & 6.9 & 165 & 159 & 163 & 21.0 & 20.5 & 21.0 \\
\hline 08-01-00 & 9.6 & 8.4 & 8.9 & .18 & -.17 & 7.2 & 6.9 & 166 & 158 & 161 & 21.0 & 20.0 & 20.5 \\
\hline $08-02-00$ & 10.0 & 8.2 & 8.8 & .23 & -.30 & 7.4 & 6.9 & 167 & 154 & 160 & 22.5 & 20.5 & 21.0 \\
\hline $08-03-00$ & 9.5 & 7.9 & 8.6 & .21 & -.24 & 7.2 & 6.8 & 165 & 154 & 160 & 22.5 & 21.0 & 22.0 \\
\hline 08-04-00 & 9.9 & 7.8 & 8.6 & .27 & -.33 & 7.6 & 6.8 & 165 & 156 & 162 & 24.5 & 21.0 & 22.5 \\
\hline $08-05-00$ & 10.0 & 7.4 & 8.4 & .35 & -.37 & 7.8 & 6.8 & 164 & 156 & 161 & 25.5 & 22.0 & 23.5 \\
\hline 08-06-00 & 10.1 & 7.2 & 8.4 & .44 & -.36 & 7.7 & 6.8 & 163 & 156 & 160 & 24.0 & 21.5 & 23.0 \\
\hline 08-07-00 & 9.5 & 7.0 & 8.0 & .39 & -.33 & 7.4 & 6.7 & 166 & 158 & 163 & 25.5 & 22.0 & 23.5 \\
\hline 08-08-00 & 9.9 & 6.8 & 8.1 & .42 & -.42 & 7.7 & 6.7 & 169 & 160 & 165 & 26.5 & 22.5 & 24.5 \\
\hline 08-09-00 & 9.8 & 6.5 & 7.8 & .40 & -.42 & 7.7 & 6.7 & 170 & 162 & 166 & 26.0 & 23.0 & 24.5 \\
\hline $08-10-00$ & -- & 6.5 & -- & nd & -.38 & -- & -- & -- & -- & -- & -- & 23.5 & -- \\
\hline $08-15-00$ & 9.9 & -- & -- & .28 & -.35 & 7.9 & -- & -- & 166 & -- & 22.0 & -- & -- \\
\hline $08-16-00$ & 9.4 & 6.9 & 8.0 & .37 & -.42 & 7.2 & 6.7 & 179 & 161 & 170 & 22.5 & 20.5 & 21.5 \\
\hline $08-17-00$ & 10.1 & 7.2 & 8.5 & .35 & -.23 & 7.5 & 6.8 & 192 & 170 & 177 & 23.0 & 19.5 & 21.0 \\
\hline $08-18-00$ & 10.0 & 7.1 & 8.4 & .33 & -.42 & 7.3 & 6.8 & 192 & 169 & 180 & 21.5 & 19.0 & 20.0 \\
\hline 08-19-00 & 10.3 & 7.2 & 8.4 & .49 & -.45 & 7.7 & 6.8 & 190 & 171 & 179 & 23.0 & 19.5 & 21.0 \\
\hline $08-20-00$ & 10.6 & 6.9 & 8.6 & .49 & -.51 & 7.7 & 6.7 & 189 & 174 & 180 & 22.5 & 18.5 & 20.5 \\
\hline $08-21-00$ & 11.0 & 7.0 & 8.8 & .53 & -.63 & 7.9 & 6.7 & 197 & 176 & 183 & 22.5 & 18.0 & 20.0 \\
\hline $08-22-00$ & 11.5 & 7.0 & 8.9 & .49 & -.46 & 8.1 & 6.7 & 197 & 179 & 188 & 22.5 & 18.5 & 20.5 \\
\hline $08-23-00$ & 10.9 & 6.9 & 8.6 & .58 & -.50 & 7.7 & 6.7 & 199 & 183 & 190 & 22.0 & 19.0 & 20.5 \\
\hline $08-24-00$ & 10.9 & 6.8 & 8.6 & .58 & -.54 & 8.0 & 6.7 & 207 & 184 & 194 & 23.0 & 19.0 & 21.0 \\
\hline $08-25-00$ & 11.3 & 6.8 & 8.6 & .44 & -.36 & 8.1 & 6.8 & 210 & 187 & 198 & 23.0 & 19.5 & 21.5 \\
\hline $08-26-00$ & 11.4 & 5.5 & 8.5 & .64 & -.83 & 8.4 & 6.8 & 212 & 187 & 198 & 24.0 & 19.5 & 22.0 \\
\hline
\end{tabular}


Appendix 2. Continuous water-quality monitor data and estimated maximum rates of instream metabolic processes at station 01125520 , Quinebaug River at Cotton Bridge Road near Pomfret Landing, Conn.-Continued

[mg/L, milligrams per liter; $\mathrm{P}_{\max }$ (maximum rate of productivity) and $\mathrm{R}_{\max }$ (maximum rate of respiration) in grams of oxygen per cubic meter per hour $\left(\mathrm{g} \mathrm{O}_{2} / \mathrm{m}^{3} / \mathrm{hr}\right.$ ) estimated from diel changes in dissolved oxygen concentrations; $\mu \mathrm{S} / \mathrm{cm}$, microsiemens per centimeter at 25 degrees Celsius; --, data not available due to partial record; nd, not determined due to equipment malfunction or changes in dissolved oxygen concentration that result from rapid changes in streamflow]

\begin{tabular}{|c|c|c|c|c|c|c|c|c|c|c|c|c|c|}
\hline \multirow[t]{2}{*}{ Date } & \multicolumn{3}{|c|}{$\begin{array}{l}\text { Dissolved oxygen } \\
\text { (mg/L) }\end{array}$} & \multicolumn{2}{|c|}{$\begin{array}{l}\text { Productivity/ } \\
\text { respiration }\end{array}$} & \multicolumn{2}{|c|}{$\begin{array}{c}\mathrm{pH} \\
\text { (standard units) }\end{array}$} & \multicolumn{3}{|c|}{$\begin{array}{l}\text { Specific conductance } \\
(\mu \mathrm{S} / \mathrm{cm})\end{array}$} & \multicolumn{3}{|c|}{$\begin{array}{l}\text { Water temperature } \\
\text { (degrees Celsius) }\end{array}$} \\
\hline & Max & Min & Mean & $P \max$ & $R \max$ & Max & Min & Max & Min & Mean & Max & Min & Mean \\
\hline $08-27-00$ & 11.9 & 5.4 & 8.1 & .71 & -.77 & 8.6 & 6.8 & 203 & 189 & 197 & 24.0 & 20.5 & 22.5 \\
\hline $08-28-00$ & 11.2 & 4.8 & 8.0 & .83 & -.50 & 8.2 & 6.8 & 208 & 190 & 199 & 23.5 & 21.5 & 22.5 \\
\hline $08-29-00$ & -- & 6.2 & -- & nd & nd & 8.6 & 6.8 & 212 & 190 & 201 & 23.5 & 20.0 & 22.0 \\
\hline $08-30-00$ & -- & -- & -- & nd & nd & 8.1 & 6.8 & 210 & 193 & 203 & 22.5 & 20.0 & 21.5 \\
\hline $08-31-00$ & -- & -- & -- & nd & nd & 8.5 & 6.8 & 216 & 196 & 207 & 24.5 & 21.5 & 23.0 \\
\hline 09-01-00 & -- & -- & -- & nd & nd & 8.0 & 6.8 & 218 & 200 & 210 & 24.5 & 23.0 & 24.0 \\
\hline 09-02-00 & -- & -- & -- & nd & nd & 7.6 & 6.8 & 220 & 200 & 211 & 24.5 & 23.0 & 23.5 \\
\hline 09-03-00 & -- & -- & -- & nd & nd & 8.2 & 6.8 & 215 & 201 & 209 & 24.0 & 21.5 & 22.5 \\
\hline 09-04-00 & -- & -- & -- & nd & nd & 7.8 & 6.8 & 212 & 195 & 200 & 24.5 & 23.0 & 23.5 \\
\hline $09-05-00$ & -- & -- & -- & nd & nd & 8.3 & 6.9 & 206 & 190 & 198 & 23.0 & 19.0 & 20.5 \\
\hline 09-06-00 & -- & -- & -- & nd & nd & 8.5 & 6.9 & 211 & 195 & 204 & 20.5 & 17.5 & 19.0 \\
\hline 09-07-00 & -- & -- & -- & nd & nd & 8.8 & 6.9 & 212 & 197 & 205 & 20.5 & 17.5 & 19.0 \\
\hline 09-08-00 & -- & -- & -- & nd & nd & 8.9 & 7.0 & 218 & 201 & 210 & 21.0 & 18.0 & 19.5 \\
\hline 09-09-00 & -- & -- & -- & nd & nd & 8.6 & 7.0 & 225 & 205 & 215 & 21.5 & 20.0 & 21.0 \\
\hline $09-10-00$ & -- & -- & -- & nd & nd & 8.6 & 6.9 & 219 & 205 & 213 & 22.5 & 20.0 & 21.5 \\
\hline $09-11-00$ & -- & -- & -- & nd & nd & 8.8 & 7.0 & 218 & 206 & 214 & 22.5 & 20.5 & 21.5 \\
\hline $09-12-00$ & -- & -- & -- & nd & nd & 8.7 & 7.0 & 227 & 208 & 219 & 22.5 & 20.5 & 21.5 \\
\hline $09-13-00$ & -- & -- & -- & nd & nd & 8.5 & 7.0 & 226 & 205 & 217 & 23.5 & 22.0 & 22.5 \\
\hline 09-14-00 & -- & -- & -- & nd & nd & 8.3 & 6.9 & 232 & 211 & 222 & 22.5 & 19.5 & 21.0 \\
\hline $09-15-00$ & -- & -- & -- & nd & nd & 7.8 & 7.0 & 236 & 182 & 211 & 21.0 & 19.5 & 20.5 \\
\hline 09-16-00 & -- & -- & -- & nd & nd & 8.2 & 7.0 & 221 & 196 & 204 & 20.5 & 18.0 & 19.0 \\
\hline $09-17-00$ & -- & -- & -- & nd & nd & 8.4 & 7.0 & 221 & 194 & 210 & 19.5 & 16.0 & 18.0 \\
\hline 09-18-00 & -- & -- & -- & nd & nd & -- & -- & 214 & -- & -- & -- & 16.5 & -- \\
\hline 09-19-00 & -- & -- & -- & nd & nd & 8.1 & -- & -- & 204 & -- & 20.0 & -- & -- \\
\hline 09-20-00 & -- & -- & -- & nd & nd & 8.4 & 6.8 & 223 & 181 & 202 & 22.5 & 19.5 & 20.5 \\
\hline $09-21-00$ & -- & -- & -- & nd & nd & 8.4 & 6.8 & 219 & 197 & 208 & 21.5 & 19.0 & 20.5 \\
\hline $09-22-00$ & 11.0 & -- & -- & nd & -.55 & 8.3 & 6.9 & 221 & 191 & 205 & 20.5 & 17.5 & 19.0 \\
\hline $09-23-00$ & 10.5 & 6.7 & 8.4 & .47 & -.47 & 8.0 & 6.8 & 221 & 193 & 208 & 19.0 & 16.5 & 18.0 \\
\hline $09-24-00$ & 9.6 & 6.3 & 7.8 & .38 & -.39 & 7.7 & 6.8 & 223 & 207 & 214 & 19.5 & 18.5 & 19.0 \\
\hline $09-25-00$ & 10.8 & 6.4 & 8.3 & .59 & -.49 & 8.0 & 6.9 & 235 & 209 & 219 & 19.0 & 16.5 & 17.5 \\
\hline $09-26-00$ & 9.1 & 6.6 & 7.9 & .25 & -.18 & 7.4 & 6.9 & 238 & 210 & 223 & 17.5 & 15.0 & 16.0 \\
\hline $09-27-00$ & 10.9 & 7.1 & 8.8 & .52 & -.56 & 8.0 & 6.9 & 231 & 213 & 222 & 17.5 & 14.0 & 15.5 \\
\hline $09-28-00$ & 11.4 & 7.2 & 9.1 & .48 & -.46 & 8.3 & 6.9 & 226 & 203 & 213 & 17.0 & 14.5 & 15.5 \\
\hline 09-29-00 & 11.4 & 7.6 & 9.4 & .42 & -.52 & 7.8 & 6.9 & 226 & 208 & 217 & 15.5 & 12.0 & 13.5 \\
\hline $09-30-00$ & 11.3 & 7.9 & 9.5 & .39 & -.36 & 7.8 & 6.9 & 226 & 204 & 212 & 14.5 & 11.5 & 13.5 \\
\hline $10-01-00$ & 11.4 & 7.2 & 9.4 & .40 & -.47 & 7.9 & 6.9 & 225 & 206 & 216 & 16.0 & 13.0 & 14.5 \\
\hline $10-02-00$ & 11.5 & 6.9 & 9.1 & .46 & -.46 & 8.0 & 6.9 & 219 & 202 & 212 & 16.5 & 14.5 & 15.5 \\
\hline $10-03-00$ & 11.3 & 6.8 & 8.7 & .33 & -.56 & 8.0 & 6.9 & 232 & 207 & 219 & 17.0 & 15.0 & 16.0 \\
\hline $10-04-00$ & 11.9 & 6.3 & 9.0 & .74 & -.39 & 8.0 & 6.9 & 233 & 214 & 225 & 16.5 & 14.5 & 15.5 \\
\hline $10-05-00$ & 11.0 & 7.7 & 9.0 & .33 & -.15 & 7.7 & 6.9 & 238 & 211 & 226 & 16.5 & 15.0 & 15.5 \\
\hline $10-06-00$ & 11.0 & 7.6 & 8.8 & .50 & -.22 & 7.3 & 6.8 & 234 & 213 & 224 & 15.5 & 14.5 & 15.0 \\
\hline $10-07-00$ & 11.9 & 8.4 & 9.8 & .45 & -.52 & 8.0 & 6.9 & 220 & 197 & 206 & 16.0 & 14.0 & 15.0 \\
\hline $10-08-00$ & 11.8 & 8.1 & 9.8 & .44 & -.41 & 7.9 & 6.9 & 216 & 198 & 204 & 15.0 & 13.0 & 14.0 \\
\hline $10-09-00$ & 11.8 & 7.5 & 9.6 & .57 & -.32 & 7.5 & 6.8 & 219 & 201 & 208 & 14.5 & 11.5 & 12.5 \\
\hline $10-10-00$ & 11.9 & 8.9 & 10.4 & .37 & -.31 & 7.4 & 6.9 & 232 & 219 & 225 & 12.0 & 10.5 & 11.0 \\
\hline $10-11-00$ & 12.0 & 8.7 & 10.2 & .35 & nd & 7.3 & 6.9 & 240 & 222 & 232 & 12.5 & 10.0 & 11.5 \\
\hline
\end{tabular}


Appendix 2. Continuous water-quality monitor data and estimated maximum rates of instream metabolic processes at station 01125520 , Quinebaug River at Cotton Bridge Road near Pomfret Landing, Conn._-Continued

[mg/L, milligrams per liter; $\mathrm{P}_{\max }$ (maximum rate of productivity) and $\mathrm{R}_{\max }$ (maximum rate of respiration) in grams of oxygen per cubic meter per hour $\left(\mathrm{g} \mathrm{O}_{2} / \mathrm{m}^{3} / \mathrm{hr}\right.$ ) estimated from diel changes in dissolved oxygen concentrations; $\mu \mathrm{S} / \mathrm{cm}$, microsiemens per centimeter at 25 degrees Celsius; --, data not available due to partial record; nd, not determined due to equipment malfunction or changes in dissolved oxygen concentration that result from rapid changes in streamflow]

\begin{tabular}{|c|c|c|c|c|c|c|c|c|c|c|c|c|c|}
\hline \multirow{2}{*}{ Date } & \multicolumn{3}{|c|}{$\begin{array}{c}\text { Dissolved oxygen } \\
\text { (mg/L) }\end{array}$} & \multicolumn{2}{|c|}{$\begin{array}{l}\text { Productivity/ } \\
\text { respiration }\end{array}$} & \multicolumn{2}{|c|}{$\begin{array}{c}\mathrm{pH} \\
\text { (standard units) }\end{array}$} & \multicolumn{3}{|c|}{$\begin{array}{l}\text { Specific conductance } \\
(\mu \mathrm{S} / \mathrm{cm})\end{array}$} & \multicolumn{3}{|c|}{$\begin{array}{l}\text { Water temperature } \\
\text { (degrees Celsius) }\end{array}$} \\
\hline & Max & Min & Mean & Pmax & $R \max$ & Max & Min & Max & Min & Mean & Max & Min & Mean \\
\hline $10-12-00$ & -- & -- & -- & nd & nd & 7.4 & 6.9 & 249 & 231 & 243 & 13.0 & 10.0 & 11.5 \\
\hline $10-13-00$ & -- & -- & -- & nd & nd & 7.3 & 6.9 & 252 & 244 & 248 & 13.0 & 10.0 & 11.5 \\
\hline $10-14-00$ & -- & -- & -- & nd & nd & 7.6 & 6.9 & 266 & 243 & 254 & 14.5 & 11.5 & 13.0 \\
\hline $10-15-00$ & -- & -- & -- & nd & nd & 7.8 & 6.8 & 251 & 234 & 240 & 14.5 & 12.5 & 13.5 \\
\hline $10-16-00$ & -- & -- & -- & nd & nd & 7.7 & 6.9 & 251 & 236 & 243 & 14.5 & 11.5 & 13.0 \\
\hline $10-17-00$ & -- & -- & -- & nd & nd & 8.1 & 7.0 & 251 & 226 & 234 & 13.5 & 11.5 & 12.5 \\
\hline $10-18-00$ & 9.9 & 9.1 & 9.4 & .16 & -.13 & 7.3 & 7.1 & 233 & 220 & 226 & 12.5 & 12.5 & 12.5 \\
\hline $10-19-00$ & 10.9 & 9.0 & 9.7 & .25 & -.23 & 7.4 & 7.0 & 220 & 212 & 217 & 13.5 & 12.0 & 12.5 \\
\hline $10-20-00$ & 11.3 & 8.9 & 9.9 & .33 & -.36 & 7.3 & 6.9 & 219 & 205 & 212 & 13.0 & 10.5 & 11.5 \\
\hline $10-21-00$ & 11.3 & 9.0 & 9.9 & .35 & -.34 & 7.4 & 6.9 & 211 & 188 & 196 & 14.0 & 11.0 & 12.5 \\
\hline $10-22-00$ & 11.6 & 8.7 & 10.0 & .41 & -.34 & 7.4 & 6.8 & 193 & 180 & 186 & 13.5 & 11.0 & 12.0 \\
\hline $10-23-00$ & 12.3 & 9.3 & 10.5 & .40 & -.37 & 7.4 & 6.8 & 189 & 175 & 182 & 12.0 & 9.5 & 11.0 \\
\hline $10-24-00$ & 12.5 & 9.5 & 10.8 & .38 & -.46 & 7.5 & 6.8 & 185 & 171 & 178 & 12.5 & 9.5 & 11.0 \\
\hline $10-25-00$ & 12.6 & 9.5 & 10.7 & .44 & -.43 & 7.5 & 6.8 & 184 & 170 & 177 & 13.0 & 10.0 & 11.5 \\
\hline $10-26-00$ & 12.8 & 9.2 & 10.7 & .49 & -.50 & 7.8 & 6.8 & 182 & 167 & 174 & 13.5 & 11.0 & 12.5 \\
\hline $10-27-00$ & 12.9 & 9.3 & 10.6 & .51 & -.46 & 7.9 & 6.8 & 184 & 170 & 176 & 13.5 & 12.0 & 12.5 \\
\hline $10-28-00$ & 12.7 & 9.2 & 10.6 & .54 & -.31 & 7.9 & 6.8 & 189 & 173 & 180 & 13.0 & 10.5 & 12.0 \\
\hline $10-29-00$ & 13.9 & 10.0 & 11.7 & .55 & -.30 & 7.9 & 6.8 & 189 & 179 & 184 & 10.5 & 8.0 & 9.0 \\
\hline $10-30-00$ & 14.5 & 10.8 & 12.4 & .51 & -.47 & 7.9 & 6.8 & 196 & 180 & 188 & 8.5 & 7.0 & 7.5 \\
\hline $10-31-00$ & 13.0 & 10.9 & 11.8 & .38 & -.32 & 7.6 & 6.9 & 198 & 183 & 190 & 8.5 & 7.5 & 8.0 \\
\hline $11-01-00$ & 14.0 & 10.6 & 11.9 & .56 & -.48 & 8.4 & 7.0 & 198 & 182 & 190 & 9.0 & 7.5 & 8.0 \\
\hline $11-02-00$ & 13.8 & 10.5 & 11.8 & .58 & -.50 & 8.3 & 7.1 & 200 & 185 & 192 & 10.0 & 7.5 & 8.5 \\
\hline $11-03-00$ & 14.0 & 10.3 & 11.6 & .69 & -.53 & 8.5 & 7.1 & 201 & 187 & 194 & 9.5 & 8.0 & 8.5 \\
\hline $11-04-00$ & 13.6 & 10.1 & 11.5 & .59 & -.53 & 8.3 & 7.1 & 198 & 187 & 193 & 10.0 & 8.0 & 9.0 \\
\hline $11-05-00$ & 12.9 & 10.0 & 11.2 & .51 & -.42 & 7.8 & 7.1 & 197 & 186 & 191 & 9.5 & 8.5 & 8.9 \\
\hline $11-06-00$ & 13.8 & 10.3 & 11.6 & .65 & -.49 & 8.4 & 7.0 & 197 & 185 & 191 & 9.0 & 7.5 & 8.0 \\
\hline $11-07-00$ & 14.0 & 10.1 & 11.6 & .51 & -.62 & 8.3 & 7.1 & 198 & 185 & 192 & 9.5 & 7.0 & 8.0 \\
\hline $11-08-00$ & 14.2 & 9.8 & 11.6 & .51 & -.62 & 8.5 & 7.1 & 198 & 184 & 191 & 9.5 & 7.5 & 8.5 \\
\hline $11-09-00$ & -- & -- & -- & nd & nd & 8.5 & 7.1 & 198 & 184 & 192 & 10.0 & 8.0 & 9.0 \\
\hline $11-10-00$ & -- & -- & -- & nd & nd & 7.4 & 7.1 & 197 & 167 & 181 & 10.0 & 9.5 & 9.5 \\
\hline $11-11-00$ & -- & -- & -- & nd & nd & 7.3 & 7.1 & 178 & 169 & 174 & 9.5 & 9.0 & 9.5 \\
\hline $11-12-00$ & --- & -- & -- & nd & nd & 7.6 & 7.1 & 171 & 164 & 166 & 10.0 & 9.0 & 9.5 \\
\hline $11-13-00$ & -- & -- & -- & nd & nd & 7.3 & 7.1 & 178 & 161 & 167 & 9.5 & 9.0 & 9.0 \\
\hline $11-14-00$ & -- & -- & -- & nd & nd & 7.2 & 7.1 & 183 & 166 & 174 & 9.5 & 9.0 & 9.0 \\
\hline $11-15-00$ & -- & -- & -- & nd & nd & 7.5 & 7.1 & 181 & 161 & 170 & 9.0 & 8.0 & 8.5 \\
\hline $11-16-00$ & -- & -- & -- & nd & nd & 7.4 & 6.9 & 173 & 160 & 167 & 8.5 & 7.5 & 7.5 \\
\hline $11-17-00$ & -- & -- & -- & nd & nd & 7.4 & 6.9 & 173 & 161 & 168 & 8.5 & 7.5 & 8.0 \\
\hline $11-18-00$ & -- & -- & -- & nd & nd & 7.4 & 6.9 & 178 & 162 & 169 & 7.5 & 6.0 & 6.5 \\
\hline $11-19-00$ & --- & -- & -- & nd & nd & 7.5 & 6.9 & 173 & 162 & 168 & 7.0 & 5.5 & 6.5 \\
\hline $11-20-00$ & -- & -- & -- & nd & nd & 7.4 & 6.9 & 177 & 163 & 170 & 6.0 & 5.0 & 5.5 \\
\hline $11-21-00$ & -- & -- & -- & nd & nd & 7.4 & 6.9 & 179 & 166 & 173 & 5.5 & 4.0 & 5.0 \\
\hline $11-22-00$ & -- & -- & -- & nd & nd & 7.4 & 6.9 & 185 & 169 & 177 & 5.0 & 3.5 & 4.0 \\
\hline $11-23-00$ & -- & -- & -- & nd & nd & 7.4 & 7.0 & 185 & 171 & 177 & 3.5 & 2.5 & 3.0 \\
\hline $11-24-00$ & -- & -- & -- & nd & nd & 7.3 & 6.9 & 182 & 173 & 177 & 2.5 & 1.0 & 1.5 \\
\hline $11-25-00$ & -- & -- & -- & nd & nd & 7.2 & 6.8 & 184 & 177 & 181 & 2.0 & 0.5 & 1.0 \\
\hline $11-26-00$ & --- & -- & -- & nd & nd & 7.0 & 6.9 & 188 & 169 & 180 & 3.5 & 1.5 & 2.5 \\
\hline
\end{tabular}


Appendix 2. Continuous water-quality monitor data and estimated maximum rates of instream metabolic processes at station 01125520 , Quinebaug River at Cotton Bridge Road near Pomfret Landing, Conn.-Continued

[mg/L, milligrams per liter; $\mathrm{P}_{\max }$ (maximum rate of productivity) and $\mathrm{R}_{\max }$ (maximum rate of respiration) in grams of oxygen per cubic meter per hour $\left(\mathrm{g} \mathrm{O}_{2} / \mathrm{m}^{3} / \mathrm{hr}\right)$ estimated from diel changes in dissolved oxygen concentrations; $\mu \mathrm{S} / \mathrm{cm}$, microsiemens per centimeter at 25 degrees Celsius; --, data not available due to partial record; nd, not determined due to equipment malfunction or changes in dissolved oxygen concentration that result from rapid changes in streamflow

\begin{tabular}{|c|c|c|c|c|c|c|c|c|c|c|c|c|c|}
\hline \multirow[t]{2}{*}{ Date } & \multicolumn{3}{|c|}{$\begin{array}{l}\text { Dissolved oxygen } \\
\text { (mg/L) }\end{array}$} & \multicolumn{2}{|c|}{$\begin{array}{l}\text { Productivity/ } \\
\text { respiration }\end{array}$} & \multicolumn{2}{|c|}{$\begin{array}{c}\mathrm{pH} \\
\text { (standard units) }\end{array}$} & \multicolumn{3}{|c|}{$\begin{array}{l}\text { Specific conductance } \\
(\mu \mathrm{S} / \mathrm{cm})\end{array}$} & \multicolumn{3}{|c|}{$\begin{array}{l}\text { Water temperature } \\
\text { (degrees Celsius) }\end{array}$} \\
\hline & Max & Min & Mean & Pmax & Rmax & Max & Min & Max & Min & Mean & Max & Min & Mean \\
\hline $11-27-00$ & -- & -- & -- & nd & nd & 7.3 & 6.9 & 193 & 176 & 183 & 4.5 & 3.5 & 4.0 \\
\hline $11-28-00$ & -- & -- & -- & nd & nd & 7.3 & 6.9 & 186 & 171 & 178 & 4.5 & 3.5 & 4.0 \\
\hline $11-29-00$ & -- & -- & -- & nd & nd & 7.3 & 6.9 & 185 & 173 & 179 & 4.5 & 3.0 & 4.0 \\
\hline $11-30-00$ & -- & -- & -- & nd & nd & 7.2 & 6.8 & 190 & 171 & 180 & 4.0 & 3.5 & 3.5 \\
\hline 04-26-01 & 11.8 & 9.4 & 10.4 & .38 & nd & 8.3 & 7.2 & 180 & 176 & 178 & 16.5 & $13 . .5$ & 15.0 \\
\hline 04-27-01 & 11.9 & 9.2 & 10.4 & .44 & nd & 8.4 & 7.3 & 182 & 177 & 179 & 16.5 & 13.5 & 15.0 \\
\hline 04-28-01 & 12.4 & 9.2 & 10.6 & .46 & nd & 8.7 & 7.2 & 180 & 176 & 177 & 17.0 & 14.0 & 15.0 \\
\hline 04-29-01 & 12.8 & 9.4 & 10.9 & .54 & nd & 9.3 & 7.2 & 185 & 176 & 180 & 16.5 & 12.5 & 14.0 \\
\hline 04-30-01 & 12.8 & 9.4 & 10.8 & .58 & nd & 9.4 & 7.3 & 195 & 185 & 188 & 16.5 & 12.5 & 14.5 \\
\hline $05-01-01$ & 12.1 & 8.9 & 10.4 & .54 & nd & 9.3 & 7.2 & 195 & 186 & 192 & 18.0 & 14.5 & 16.0 \\
\hline $05-02-01$ & 12.2 & 8.4 & 10.2 & .56 & nd & 9.5 & 7.2 & 213 & 189 & 200 & 19.5 & 15.5 & 17.5 \\
\hline 05-03-01 & 12.8 & 7.8 & 10.1 & .66 & nd & 9.8 & 7.0 & 207 & 185 & 197 & 21.5 & 17.0 & 19.0 \\
\hline $05-04-01$ & 12.2 & 7.5 & 9.6 & .68 & nd & 9.7 & 7.0 & 204 & 188 & 196 & 22.5 & 18.5 & 20.5 \\
\hline $05-05-01$ & 11.9 & 7.2 & 9.3 & .59 & nd & 9.2 & 7.0 & 204 & 188 & 195 & 21.0 & 18.5 & 20.0 \\
\hline $05-06-01$ & 11.7 & 7.6 & 9.4 & .52 & nd & 8.8 & 7.0 & 204 & 188 & 195 & 20.0 & 16.5 & 18.0 \\
\hline $05-07-01$ & 11.9 & 7.8 & 9.7 & .54 & nd & 8.6 & 7.1 & 210 & 197 & 203 & 19.5 & 14.5 & 17.0 \\
\hline $05-08-01$ & 12.0 & 8.2 & 9.8 & .48 & nd & 8.2 & 7.0 & 223 & 200 & 210 & 19.5 & 14.5 & 16.5 \\
\hline $05-09-01$ & 11.7 & 8.1 & 9.6 & .46 & nd & 7.9 & 6.9 & 224 & 210 & 217 & 20.0 & 15.0 & 17.5 \\
\hline $05-10-01$ & 11.3 & 7.6 & 9.2 & .44 & nd & 7.8 & 6.9 & 224 & 205 & 214 & 21.0 & 16.0 & 18.5 \\
\hline $05-11-01$ & 11.1 & 7.4 & 9.0 & .41 & nd & 7.8 & 6.9 & 230 & 211 & 219 & 22.5 & 17.0 & 19.5 \\
\hline $05-12-01$ & 11.0 & 7.2 & 8.7 & .54 & nd & 8.0 & 6.9 & 235 & 219 & 227 & 23.0 & 18.0 & 20.5 \\
\hline $05-13-01$ & 10.9 & 7.1 & 8.8 & .51 & nd & 7.7 & 6.8 & 230 & 215 & 222 & 21.0 & 18.0 & 19.5 \\
\hline $05-14-01$ & 10.7 & 7.7 & 9.2 & .42 & nd & 7.6 & 6.9 & 234 & 218 & 225 & 19.5 & 16.5 & 18.0 \\
\hline $05-15-01$ & 11.2 & 8.0 & 9.5 & .37 & nd & 7.7 & 6.9 & 238 & 220 & 228 & 17.5 & 15.5 & 16.5 \\
\hline $05-16-01$ & 10.8 & 8.4 & 9.6 & .33 & nd & 7.3 & 6.9 & 239 & 222 & 230 & 16.0 & 14.5 & 15.0 \\
\hline $05-17-01$ & 11.7 & 8.7 & 10.1 & .36 & nd & 7.6 & 6.9 & 239 & 223 & 232 & 16.5 & 14.0 & 15.0 \\
\hline $05-18-01$ & 10.8 & 8.8 & 9.7 & .25 & nd & 7.3 & 6.9 & 239 & 224 & 231 & 15.5 & 14.5 & 15.0 \\
\hline $05-19-01$ & 11.1 & 8.7 & 9.9 & .32 & nd & 7.5 & 6.9 & 239 & 225 & 232 & 19.0 & 14.0 & 16.5 \\
\hline $05-20-01$ & 11.3 & 8.4 & 9.6 & .36 & nd & 7.6 & 6.8 & 237 & 225 & 232 & 20.5 & 15.0 & 16.0 \\
\hline $05-21-01$ & 11.0 & 8.0 & 9.4 & .39 & nd & 7.6 & 6.8 & 258 & 229 & 239 & 18.0 & 15.5 & 16.5 \\
\hline $05-22-01$ & 9.4 & 7.9 & 8.6 & .18 & nd & 7.1 & 6.8 & 250 & 225 & 236 & 18.0 & 16.0 & 16.5 \\
\hline $05-23-01$ & 9.5 & 8.4 & 9.0 & .14 & nd & 7.1 & 6.9 & 238 & 224 & 232 & 16.0 & 15.5 & 16.0 \\
\hline $05-24-01$ & 10.1 & 9.0 & 9.6 & .11 & nd & 7.3 & 7.0 & 235 & 211 & 225 & 16.0 & 15.0 & 15.5 \\
\hline $05-25-01$ & 10.7 & 9.4 & 10.0 & .16 & nd & 7.5 & 7.1 & 227 & 211 & 219 & 17.0 & 15.0 & 16.0 \\
\hline $05-26-01$ & 10.8 & 9.2 & 9.9 & .21 & nd & 7.5 & 7.0 & 221 & 205 & 211 & 18.0 & 15.5 & 16.5 \\
\hline $05-27-01$ & 10.2 & 9.1 & 9.5 & .19 & nd & 7.3 & 6.9 & 209 & 199 & 204 & 18.0 & 16.0 & 17.0 \\
\hline $05-28-01$ & 10.2 & 9.0 & 9.5 & .22 & nd & 7.3 & 7.0 & 207 & 197 & 201 & 18.5 & 16.5 & 17.5 \\
\hline $05-29-01$ & 10.2 & 8.8 & 9.5 & .17 & nd & 7.3 & 6.9 & 205 & 191 & 198 & 19.0 & 16.0 & 17.5 \\
\hline $05-30-01$ & 10.3 & 8.8 & 9.5 & .21 & -.18 & 7.4 & 6.9 & 204 & 188 & 197 & 19.0 & 16.5 & 17.5 \\
\hline $05-31-01$ & 10.6 & 9.1 & 9.8 & .22 & -.20 & 7.4 & 6.9 & 202 & 191 & 197 & 18.5 & 15.5 & 17.0 \\
\hline 06-01-01 & 10.9 & 8.8 & 9.9 & .25 & -.28 & 7.6 & 6.9 & 207 & 193 & 200 & 19.5 & 15.0 & 17.0 \\
\hline $06-02-01$ & 9.9 & 8.8 & 9.5 & nd & -.08 & 7.1 & 6.8 & 203 & 180 & 191 & 17.5 & 16.0 & 16.5 \\
\hline 06-03-01 & 10.1 & 9.2 & 9.6 & .09 & -.16 & 7.2 & 6.9 & 189 & 182 & 187 & 18.5 & 17.0 & 17.5 \\
\hline 06-04-01 & 10.1 & 9.3 & 9.7 & .11 & -.10 & 7.2 & 6.9 & 193 & 181 & 187 & 18.0 & 16.5 & 17.5 \\
\hline $06-05-01$ & 10.2 & 9.1 & 9.7 & .14 & -.14 & 7.2 & 6.9 & 194 & 183 & 189 & 19.5 & 16.5 & 18.0 \\
\hline 06-06-01 & 9.9 & 8.9 & 9.5 & .14 & -.16 & 7.1 & 6.8 & 194 & 186 & 189 & 20.0 & 18.0 & 19.0 \\
\hline
\end{tabular}


Appendix 2. Continuous water-quality monitor data and estimated maximum rates of instream metabolic processes at station 01125520 , Quinebaug River at Cotton Bridge Road near Pomfret Landing, Conn.-Continued

[mg/L, milligrams per liter; $\mathrm{P}_{\max }$ (maximum rate of productivity) and $\mathrm{R}_{\max }$ (maximum rate of respiration) in grams of oxygen per cubic meter per hour $\left(\mathrm{g} \mathrm{O}_{2} / \mathrm{m}^{3} / \mathrm{hr}\right.$ ) estimated from diel changes in dissolved oxygen concentrations; $\mu \mathrm{S} / \mathrm{cm}$, microsiemens per centimeter at 25 degrees Celsius; --, data not available due to partial record; nd, not determined due to equipment malfunction or changes in dissolved oxygen concentration that result from rapid changes in streamflow]

\begin{tabular}{|c|c|c|c|c|c|c|c|c|c|c|c|c|c|}
\hline \multirow{2}{*}{ Date } & \multicolumn{3}{|c|}{$\begin{array}{c}\text { Dissolved oxygen } \\
\text { (mg/L) }\end{array}$} & \multicolumn{2}{|c|}{$\begin{array}{l}\text { Productivity/ } \\
\text { respiration }\end{array}$} & \multicolumn{2}{|c|}{$\begin{array}{c}\mathrm{pH} \\
\text { (standard units) }\end{array}$} & \multicolumn{3}{|c|}{$\begin{array}{l}\text { Specific conductance } \\
(\mu \mathrm{S} / \mathrm{cm})\end{array}$} & \multicolumn{3}{|c|}{$\begin{array}{l}\text { Water temperature } \\
\text { (degrees Celsius) }\end{array}$} \\
\hline & Max & Min & Mean & Pmax & $R \max$ & Max & Min & Max & Min & Mean & Max & Min & Mean \\
\hline $06-07-01$ & -- & -- & -- & .18 & nd & -- & -- & -- & 185 & -- & -- & -- & -- \\
\hline 07-05-01 & 10.4 & -- & -- & nd & -.46 & -- & -- & 233 & -- & -- & -- & -- & -- \\
\hline 07-06-01 & 10.2 & 7.2 & 8.6 & .42 & -.35 & 8.0 & 6.8 & 215 & 197 & 206 & 24.0 & 21.5 & 22.5 \\
\hline $07-07-01$ & 11.2 & 7.5 & 9.1 & .50 & -.52 & 8.5 & 6.8 & 207 & 191 & 199 & 24.5 & 20.5 & 22.5 \\
\hline 07-08-01 & 9.0 & 7.1 & 8.0 & .25 & -.18 & 7.0 & 6.8 & 208 & 194 & 201 & 22.5 & 21.0 & 21.5 \\
\hline 07-09-01 & 10.5 & 7.5 & 8.7 & .42 & -.43 & 7.8 & 6.8 & 214 & 193 & 204 & 25.5 & 20.5 & 23.0 \\
\hline 07-10-01 & 10.4 & 6.9 & 8.3 & .46 & -.47 & 7.9 & 6.8 & 212 & 179 & 204 & 26.5 & 21.5 & 24.0 \\
\hline 07-11-01 & 9.6 & 6.9 & 8.1 & .33 & -.29 & 7.6 & 6.7 & 199 & 178 & 189 & 24.5 & 21.5 & 22.5 \\
\hline $07-12-01$ & 10.0 & 7.5 & 8.5 & .33 & -.29 & 7.7 & 6.8 & 210 & 193 & 200 & 24.0 & 21.0 & 22.5 \\
\hline 07-13-01 & 10.2 & 7.5 & 8.7 & .36 & -.37 & 7.9 & 6.8 & 208 & 190 & 200 & 24.0 & 20.0 & 22.0 \\
\hline $07-14-01$ & 10.4 & 7.4 & 8.7 & .44 & -.37 & 7.8 & 6.8 & 202 & 189 & 196 & 23.5 & 20.0 & 21.5 \\
\hline $07-15-01$ & 11.1 & 7.2 & 8.9 & .52 & -.50 & 8.4 & 6.8 & 203 & 190 & 196 & 24.5 & 20.0 & 22.5 \\
\hline $07-16-01$ & 11.6 & 7.0 & 8.9 & .62 & -.57 & 8.7 & 6.8 & 215 & 194 & 203 & 25.5 & 20.5 & 23.0 \\
\hline $07-17-01$ & 9.8 & 6.7 & 8.1 & .31 & -.30 & 7.4 & 6.8 & 220 & 198 & 208 & 23.5 & 21.5 & 22.0 \\
\hline 07-18-01 & 11.5 & 7.2 & 9.1 & .62 & -.56 & 8.4 & 6.8 & 221 & 199 & 210 & 25.5 & 21.0 & 23.0 \\
\hline 07-19-01 & 11.1 & 6.8 & 8.7 & .59 & -.48 & 8.2 & 6.7 & 224 & 203 & 213 & 24.0 & 21.5 & 22.5 \\
\hline $07-20-01$ & 11.5 & 7.0 & 9.0 & .63 & -.55 & 8.2 & 6.6 & 227 & 205 & 215 & 25.5 & 20.0 & 22.5 \\
\hline $07-21-01$ & 11.5 & 6.7 & 8.8 & .63 & -.56 & 8.3 & 6.6 & 226 & 208 & 216 & 26.0 & 20.5 & 23.5 \\
\hline $07-22-01$ & 11.4 & 6.4 & 8.7 & .67 & -.50 & 8.2 & 6.6 & 226 & 211 & 218 & 26.0 & 21.5 & 24.0 \\
\hline $07-23-01$ & 11.5 & 6.3 & 8.7 & .73 & -.49 & 8.4 & 6.6 & 238 & 217 & 226 & 26.0 & 21.5 & 24.0 \\
\hline 07-24-01 & 11.0 & 6.0 & 8.4 & .77 & -.53 & 8.3 & 6.5 & 245 & 218 & 233 & 27.0 & 23.0 & 25.5 \\
\hline $07-25-01$ & 11.0 & 5.4 & 8.1 & .78 & -.70 & 8.2 & 6.6 & 252 & 227 & 240 & 28.5 & 24.5 & 26.5 \\
\hline 07-26-01 & 8.1 & 5.1 & 6.7 & .28 & -.23 & 7.3 & 6.6 & 257 & 223 & 237 & 28.0 & 22.5 & 24.5 \\
\hline $07-27-01$ & 10.4 & 6.5 & 8.2 & .56 & -.51 & 7.5 & 6.7 & 254 & 227 & 239 & 24.0 & 20.0 & 22.0 \\
\hline 07-28-01 & 10.8 & 5.0 & 8.4 & .60 & -.62 & 7.9 & 6.8 & 261 & 220 & 232 & 24.0 & 20.0 & 22.5 \\
\hline 07-29-01 & 10.8 & 6.2 & 8.4 & .57 & -.52 & 8.1 & 6.8 & 260 & 222 & 231 & 24.0 & 21.0 & 22.5 \\
\hline $07-30-01$ & -- & 6.1 & -- & .55 & -.48 & 8.0 & 6.8 & 242 & -- & -- & -- & -- & -- \\
\hline $08-15-01$ & 11.1 & -- & -- & .58 & -.42 & 8.6 & -- & 213 & 189 & 198 & -- & -- & -- \\
\hline 08-16-01 & 11.0 & 7.2 & 8.9 & .44 & -.51 & 8.4 & 7.4 & 243 & 199 & 215 & 25.5 & 21.5 & 23.5 \\
\hline 08-17-01 & 10.7 & 7.0 & 8.7 & .60 & -.66 & 8.1 & 7.3 & 259 & 206 & 229 & 24.5 & 21.5 & 23.0 \\
\hline 08-18-01 & 10.9 & 6.2 & 8.5 & .55 & -.55 & 8.1 & 7.3 & 259 & 212 & 233 & 25.0 & 22.0 & 23.5 \\
\hline 08-19-01 & 10.9 & 6.8 & 8.5 & .46 & -.43 & 8.4 & 7.2 & 249 & 214 & 231 & 25.5 & 22.0 & 24.0 \\
\hline 08-20-01 & 9.8 & 6.8 & 7.9 & .53 & -.48 & 7.7 & 7.2 & 271 & 217 & 236 & 24.5 & 23.0 & 24.0 \\
\hline $08-21-01$ & 10.4 & 6.7 & 8.2 & .49 & -.49 & 8.2 & 7.2 & 251 & 211 & 230 & 26.0 & 23.0 & 24.5 \\
\hline 08-22-01 & 10.3 & 6.8 & 8.3 & .60 & -.62 & 8.0 & 7.1 & 242 & 206 & 225 & 26.5 & 22.0 & 24.0 \\
\hline 08-23-01 & 10.5 & 6.7 & 8.4 & .54 & -.45 & 7.9 & 7.1 & 247 & 209 & 226 & 24.5 & 22.0 & 23.5 \\
\hline 08-24-01 & 10.5 & 6.0 & 8.3 & .64 & -.38 & 7.8 & 7.0 & 247 & 220 & 232 & 25.0 & 22.5 & 24.0 \\
\hline $08-25-01$ & 10.5 & 6.6 & 8.4 & nd & nd & 7.6 & 7.1 & 255 & 225 & 242 & 24.0 & 21.0 & 23.0 \\
\hline 08-26-01 & 11.3 & 5.7 & 8.7 & nd & nd & 8.1 & 7.1 & 252 & 221 & 232 & 24.5 & 21.5 & 23.0 \\
\hline 08-27-01 & 10.3 & 6.6 & 8.2 & nd & nd & 7.6 & 7.0 & 263 & 225 & 243 & 23.5 & 22.0 & 23.0 \\
\hline 08-28-01 & 10.6 & 6.3 & 8.3 & nd & nd & 7.7 & 6.9 & 262 & 224 & 235 & 25.5 & 22.5 & 24.0 \\
\hline 08-29-01 & 10.3 & 4.1 & 7.0 & nd & nd & 7.4 & 7.0 & 268 & 234 & 254 & 24.5 & 22.0 & 23.5 \\
\hline 08-30-01 & 11.0 & 6.3 & 8.6 & nd & nd & 7.9 & 7.0 & 274 & 226 & 247 & 24.5 & 21.0 & 23.0 \\
\hline 08-31-01 & 10.7 & 5.5 & 8.3 & nd & nd & 7.6 & 7.0 & 255 & 231 & 247 & 24.5 & 22.5 & 23.5 \\
\hline 09-01-01 & 10.2 & 3.9 & 7.2 & nd & nd & 7.5 & 7.0 & 269 & 233 & 248 & 25.0 & 23.0 & 24.0 \\
\hline 09-02-01 & 10.4 & 4.8 & 7.8 & nd & nd & 7.6 & 7.0 & 258 & 236 & 248 & 23.0 & 19.5 & 21.0 \\
\hline
\end{tabular}


Appendix 2. Continuous water-quality monitor data and estimated maximum rates of instream metabolic processes at station 01125520 , Quinebaug River at Cotton Bridge Road near Pomfret Landing, Conn.-Continued

$\left[\mathrm{mg} / \mathrm{L}\right.$, milligrams per liter; $\mathrm{P}_{\max }$ (maximum rate of productivity) and $\mathrm{R}_{\max }$ (maximum rate of respiration) in grams of oxygen per cubic meter per hour $\left(\mathrm{g} \mathrm{O}_{2} / \mathrm{m}^{3} / \mathrm{hr}\right.$ ) estimated from diel changes in dissolved oxygen concentrations; $\mu \mathrm{S} / \mathrm{cm}$, microsiemens per centimeter at 25 degrees Celsius; --, data not available due to partial record; nd, not determined due to equipment malfunction or changes in dissolved oxygen concentration that result from rapid changes in streamflow]

\begin{tabular}{|c|c|c|c|c|c|c|c|c|c|c|c|c|c|}
\hline \multirow{2}{*}{ Date } & \multicolumn{3}{|c|}{$\begin{array}{l}\text { Dissolved oxygen } \\
\text { (mg/L) }\end{array}$} & \multicolumn{2}{|c|}{$\begin{array}{l}\text { Productivity/ } \\
\text { respiration }\end{array}$} & \multicolumn{2}{|c|}{$\begin{array}{c}\mathrm{pH} \\
\text { (standard units) }\end{array}$} & \multicolumn{3}{|c|}{$\begin{array}{l}\text { Specific conductance } \\
\qquad(\mu \mathrm{S} / \mathrm{cm})\end{array}$} & \multicolumn{3}{|c|}{$\begin{array}{l}\text { Water temperature } \\
\text { (degrees Celsius) }\end{array}$} \\
\hline & Max & Min & Mean & Pmax & Rmax & Max & Min & Max & Min & Mean & Max & Min & Mean \\
\hline 09-03-01 & 10.8 & 4.3 & 7.7 & nd & nd & 7.8 & 7.0 & 262 & 239 & 252 & 22.0 & 19.0 & 20.5 \\
\hline 09-04-01 & 10.1 & 4.0 & 7.3 & nd & nd & 7.8 & 7.0 & 267 & 237 & 253 & 21.5 & 18.5 & 20.0 \\
\hline 09-05-01 & 9.8 & 3.9 & 7.6 & nd & nd & 7.8 & 6.9 & 277 & 246 & 263 & 21.5 & 19.5 & 20.5 \\
\hline 09-06-01 & 10.0 & 6.4 & 8.1 & nd & nd & 7.8 & 6.9 & 288 & 248 & 268 & 20.5 & 18.0 & 19.5 \\
\hline 09-07-01 & 9.9 & 6.8 & 8.3 & nd & nd & 7.8 & 6.9 & 284 & 251 & 269 & 21.5 & 18.5 & 20.0 \\
\hline 09-08-01 & 10.1 & 6.4 & 8.2 & nd & nd & 8.2 & 6.9 & 289 & 250 & 270 & 22.5 & 20.0 & 21.0 \\
\hline 09-09-01 & 10.0 & 6.5 & 8.3 & nd & nd & 8.4 & 7.0 & 274 & 251 & 265 & 23.5 & 21.0 & 22.5 \\
\hline 09-10-01 & 9.7 & 6.2 & 8.0 & nd & nd & 8.3 & 7.0 & 277 & 253 & 268 & 24.5 & 22.0 & 23.5 \\
\hline 09-11-01 & 9.9 & 5.8 & 7.8 & nd & nd & 8.4 & 6.9 & 295 & 261 & 279 & 24.0 & 22.0 & 23.0 \\
\hline $09-12-01$ & 10.1 & 6.0 & 8.1 & nd & nd & 8.2 & 7.0 & 291 & 259 & 277 & 22.0 & 19.5 & 21.0 \\
\hline 09-13-01 & 10.0 & 6.5 & 8.2 & nd & nd & 8.0 & 7.1 & 293 & 259 & 279 & 22.0 & 19.0 & 20.5 \\
\hline 09-14-01 & 9.5 & 6.6 & 7.8 & nd & nd & 7.9 & 6.9 & 287 & 247 & 268 & 21.5 & 17.5 & 19.5 \\
\hline $09-15-01$ & 10.4 & 7.2 & 8.5 & nd & nd & 7.7 & 7.0 & 275 & 248 & 265 & 18.0 & 15.5 & 17.0 \\
\hline 09-16-01 & 10.1 & 7.5 & 8.8 & nd & nd & 7.6 & 7.1 & 294 & 258 & 280 & 18.5 & 16.0 & 17.5 \\
\hline 09-17-01 & 10.3 & 7.5 & 8.7 & nd & nd & 7.8 & 7.1 & 286 & 261 & 277 & 18.5 & 16.5 & 17.5 \\
\hline 09-18-01 & 10.6 & 6.5 & 8.6 & nd & nd & 8.1 & 7.0 & 311 & 267 & 292 & 19.0 & 17.0 & 18.0 \\
\hline 09-19-01 & 10.4 & 7.0 & 8.6 & nd & nd & 8.0 & 7.2 & 303 & 266 & 285 & 19.5 & 18.0 & 19.0 \\
\hline 09-20-01 & 9.9 & 6.8 & 8.4 & nd & nd & 7.8 & 7.2 & 297 & 265 & 283 & 19.0 & 18.0 & 18.5 \\
\hline 09-21-01 & -- & 6.7 & -- & nd & nd & 7.5 & 7.0 & 292 & 238 & 266 & 19.5 & 18.5 & 19.0 \\
\hline 09-22-01 & -- & -- & -- & nd & nd & 8.1 & 7.0 & 304 & 262 & 277 & 21.5 & 19.0 & 20.5 \\
\hline 09-23-01 & -- & -- & -- & nd & nd & 8.1 & 6.9 & 304 & 262 & 283 & 22.0 & 19.5 & 21.0 \\
\hline 09-24-01 & -- & -- & -- & nd & nd & 7.7 & 6.9 & 284 & 255 & 271 & 21.5 & 20.0 & 20.5 \\
\hline $09-25-01$ & -- & -- & -- & nd & nd & 7.4 & 7.0 & 290 & 247 & 268 & 21.5 & 20.5 & 21.0 \\
\hline 09-26-01 & -- & -- & -- & nd & nd & -- & -- & 265 & -- & -- & -- & -- & -- \\
\hline
\end{tabular}


44 Nutrient Enrichment, Phytoplankton Algal Growth, and Rates of Metabolism in the Quinebaug River Basin, Conn.

Appendix 3 
Appendix 3. Continuous water-quality monitor data and estimated maximum rates of instream metabolic processes at station 01126720 , Quinebaug River near Packer, Conn.

[mg/L, milligrams per liter; $\mathrm{P}_{\max }$ (maximum rate of productivity) and $\mathrm{R}_{\max }$ (maximum rate of respiration) in grams of oxygen per cubic meter per hour $\left(\mathrm{g} \mathrm{O}_{2} / \mathrm{m}^{3} / \mathrm{hr}\right.$ ) estimated from diel changes in dissolved oxygen concentrations; $\mu \mathrm{S} / \mathrm{cm}$, microsiemens per centimeter at 25 degrees Celsius; --, data not available due to partial record; nd, not determined due to equipment malfunction or changes in dissolved oxygen concentration that result from rapid changes in streamflow]

\begin{tabular}{|c|c|c|c|c|c|c|c|c|c|c|c|c|c|}
\hline \multirow{2}{*}{ Date } & \multicolumn{3}{|c|}{$\begin{array}{l}\text { Dissolved oxygen } \\
\text { (mg/L) }\end{array}$} & \multicolumn{2}{|c|}{$\begin{array}{l}\text { Productivity/ } \\
\text { respiration }\end{array}$} & \multicolumn{2}{|c|}{$\begin{array}{c}\mathrm{pH} \\
\text { (standard units) }\end{array}$} & \multicolumn{3}{|c|}{$\begin{array}{l}\text { Specific conductance } \\
(\mu \mathrm{S} / \mathrm{cm})\end{array}$} & \multicolumn{3}{|c|}{$\begin{array}{l}\text { Water temperature } \\
\text { (degrees Celsius) }\end{array}$} \\
\hline & Max & Min & Mean & Pmax & Rmax & Max & Min & Max & Min & Mean & Max & Min & Mean \\
\hline $06-17-00$ & 8.6 & 7.9 & 8.2 & 0.10 & -.11 & 6.8 & 6.5 & 122 & 117 & 119 & 22.5 & 19.5 & 21.0 \\
\hline $06-18-00$ & 8.2 & 7.6 & 7.9 & .11 & -.06 & 6.7 & 6.6 & 122 & 120 & 121 & 22.0 & 21.0 & 21.5 \\
\hline 06-19-00 & 8.3 & 7.6 & 7.9 & .09 & -.06 & 6.8 & 6.6 & 123 & 120 & 121 & 21.0 & 20.5 & 20.5 \\
\hline $06-21-00$ & 8.6 & 7.6 & 8.0 & .12 & -.12 & 6.9 & 6.6 & 126 & 123 & 125 & 22.0 & 20.5 & 21.5 \\
\hline $06-22-00$ & 8.4 & 7.4 & 7.9 & .11 & -.13 & 7.0 & 6.7 & 130 & 125 & 127 & 23.0 & 21.5 & 22.0 \\
\hline $06-23-00$ & 8.5 & 7.2 & 7.8 & .14 & -.14 & 7.1 & 6.8 & 135 & 128 & 131 & 23.5 & 21.5 & 22.5 \\
\hline $06-24-00$ & 8.7 & 7.2 & 7.8 & .18 & -.16 & 7.2 & 6.8 & 137 & 132 & 135 & 23.5 & 22.0 & 23.0 \\
\hline $06-25-00$ & 8.8 & 7.2 & 8.0 & .16 & -.17 & 7.3 & 6.8 & 140 & 135 & 138 & 24.5 & 22.5 & 23.5 \\
\hline $06-26-00$ & 8.7 & 7.0 & 7.7 & .32 & nd & 7.3 & 6.9 & 145 & 137 & 142 & 24.5 & 23.5 & 24.0 \\
\hline $06-30-00$ & 10.3 & 7.5 & 8.9 & .33 & -.19 & 8.5 & 6.9 & 141 & 134 & 138 & 23.5 & 22.5 & 23.0 \\
\hline 07-01-00 & 10.1 & 7.5 & 9.2 & .26 & -.22 & 8.3 & 7.1 & 144 & 135 & 138 & 23.5 & 22.5 & 23.0 \\
\hline $07-02-00$ & 9.7 & 7.8 & 8.7 & .31 & -.14 & 8.0 & 7.1 & 150 & 137 & 143 & 24.0 & 23.0 & 23.5 \\
\hline $07-03-00$ & 9.3 & 7.6 & 8.6 & .07 & -.15 & 7.6 & 7.2 & 153 & 141 & 146 & 24.5 & 23.5 & 24.0 \\
\hline 07-04-00 & 8.8 & 7.3 & 8.0 & nd & nd & 7.4 & 7.0 & 152 & 143 & 147 & 25.0 & 24.0 & 24.5 \\
\hline $07-05-00$ & 9.8 & 7.5 & 8.2 & nd & nd & 7.7 & 6.8 & 153 & 136 & 143 & 25.5 & 24.5 & 25.0 \\
\hline 07-06-00 & 9.2 & 7.7 & 8.3 & nd & nd & 7.2 & 6.9 & 145 & 138 & 141 & 25.5 & 24.0 & 24.5 \\
\hline $07-07-00$ & 9.1 & 7.8 & 8.5 & nd & nd & 7.2 & 6.8 & 145 & 143 & 144 & 24.5 & 23.5 & 24.0 \\
\hline 07-08-00 & 9.1 & 8.0 & 8.5 & nd & nd & 7.1 & 6.9 & 151 & 144 & 147 & 23.5 & 22.0 & 22.5 \\
\hline 07-09-00 & 9.5 & 8.1 & 8.9 & nd & nd & 7.2 & 6.9 & 153 & 150 & 152 & 22.0 & 21.5 & 22.0 \\
\hline $07-17-00$ & 9.0 & 7.3 & 8.0 & nd & nd & 7.4 & 7.0 & 148 & 140 & 144 & 24.5 & 23.5 & 23.5 \\
\hline $07-18-00$ & 8.7 & 7.8 & 8.2 & nd & nd & 7.3 & 7.1 & 152 & 142 & 147 & 25.0 & 24. & 24.5 \\
\hline 07-19-00 & 9.6 & 7.0 & 7.8 & nd & nd & 7.3 & 6.9 & 157 & 142 & 147 & 24.5 & 22.0 & 23.5 \\
\hline $07-20-00$ & 9.9 & 7.5 & 8.6 & nd & nd & 7.8 & 7.0 & 165 & 156 & 161 & 22.0 & 21.0 & 21.5 \\
\hline $07-21-00$ & 10.9 & 9.9 & 10.3 & .22 & -.08 & 8.7 & 7.5 & 174 & 162 & 166 & 23.0 & 22.0 & 22.5 \\
\hline $07-22-00$ & 10.7 & 9.7 & 10.4 & .11 & -.23 & 8.6 & 7.8 & 174 & 165 & 169 & 24.5 & 22.5 & 23.0 \\
\hline $07-23-00$ & 10.6 & 8.7 & 9.5 & .10 & -.13 & 8.6 & 7.9 & 172 & 157 & 166 & 24.0 & 23.0 & 23.5 \\
\hline $07-24-00$ & 9.7 & 8.7 & 9.4 & .15 & -.16 & 8.5 & 7.5 & 157 & 144 & 147 & 23.5 & 22.5 & 23.0 \\
\hline $07-25-00$ & 9.2 & 7.7 & 8.6 & .12 & -.16 & 7.6 & 7.1 & 148 & 141 & 143 & 23.0 & 22.0 & 23.0 \\
\hline $07-26-00$ & 8.1 & 7.4 & 7.7 & .07 & -.13 & 7.1 & 6.9 & 163 & 148 & 159 & 22.0 & 21.0 & 21.5 \\
\hline $07-27-00$ & 7.9 & 7.1 & 7.5 & .06 & nd & 7.0 & 6.8 & 169 & 161 & 164 & 21.0 & 20.0 & 20.5 \\
\hline $07-28-00$ & 9.2 & 7.8 & 8.6 & .19 & -.11 & 7.2 & 7.0 & 171 & 160 & 167 & 20.5 & 19.5 & 20.0 \\
\hline $07-29-00$ & 9.9 & 8.4 & 9.1 & .17 & -.16 & 7.5 & 7.0 & 168 & 158 & 164 & 21.5 & 20.5 & 21.0 \\
\hline $07-30-00$ & 9.6 & 8.3 & 8.9 & .13 & -.13 & 7.4 & 7.1 & 173 & 158 & 167 & 21.5 & 21.0 & 21.0 \\
\hline $07-31-00$ & 9.4 & 8.3 & 8.7 & .09 & -.06 & 7.3 & 7.0 & 158 & 142 & 152 & 21.5 & 20.5 & 21.0 \\
\hline
\end{tabular}


Appendix 3. Continuous water-quality monitor data and estimated maximum rates of instream metabolic processes at station 01126720 , Quinebaug River near Packer, Conn.-Continued

[mg/L, milligrams per liter; $\mathrm{P}_{\max }$ (maximum rate of productivity) and $\mathrm{R}_{\max }$ (maximum rate of respiration) in grams of oxygen per cubic meter per hour $\left(\mathrm{g} \mathrm{O}_{2} / \mathrm{m}^{3} / \mathrm{hr}\right.$ ) estimated from diel changes in dissolved oxygen concentrations; $\mu \mathrm{S} / \mathrm{cm}$, microsiemens per centimeter at 25 degrees Celsius; --, data not available due to partial record; nd, not determined due to equipment malfunction or changes in dissolved oxygen concentration that result from rapid changes in streamflow]

\begin{tabular}{|c|c|c|c|c|c|c|c|c|c|c|c|c|c|}
\hline \multirow{2}{*}{ Date } & \multicolumn{3}{|c|}{$\begin{array}{c}\text { Dissolved oxygen } \\
\text { (mg/L) }\end{array}$} & \multicolumn{2}{|c|}{$\begin{array}{l}\text { Productivity/ } \\
\text { respiration }\end{array}$} & \multicolumn{2}{|c|}{$\begin{array}{c}\mathrm{pH} \\
\text { (standard units) }\end{array}$} & \multicolumn{3}{|c|}{$\begin{array}{l}\text { Specific conductance } \\
(\mu \mathrm{S} / \mathrm{cm})\end{array}$} & \multicolumn{3}{|c|}{$\begin{array}{l}\text { Water temperature } \\
\text { (degrees Celsius) }\end{array}$} \\
\hline & Max & Min & Mean & Pmax & $R \max$ & Max & Min & Max & Min & Mean & Max & Min & Mean \\
\hline 08-01-00 & 9.3 & 8.5 & 8.8 & .08 & -.10 & 7.1 & 7.0 & 142 & 136 & 139 & 20.5 & 20.0 & 20.5 \\
\hline $08-02-00$ & 9.5 & 8.5 & 8.9 & .10 & -.17 & 7.1 & 6.9 & 140 & 136 & 138 & 21.5 & 20.5 & 21.0 \\
\hline 08-03-00 & -- & 8.2 & -- & nd & nd & 7.1 & 6.9 & -- & 136 & -- & -- & 21.5 & -- \\
\hline 08-04-00 & -- & 7.4 & -- & nd & nd & -- & 6.3 & 141 & -- & -- & 23.5 & -- & -- \\
\hline $08-05-00$ & 8.6 & 7.2 & 7.8 & nd & nd & 7.1 & 6.8 & 145 & 138 & 142 & 24.0 & 23.0 & 23.5 \\
\hline 08-06-00 & 8.4 & 7.2 & 7.7 & nd & nd & 7.0 & 6.8 & 148 & 142 & 144 & 24.0 & 23.0 & 23.0 \\
\hline 08-07-00 & 8.6 & 7.3 & 7.9 & nd & nd & 7.0 & 6.9 & 148 & 145 & 146 & 23.5 & 22.5 & 23.0 \\
\hline 08-08-00 & 8.1 & 7.5 & 7.8 & nd & nd & 7.0 & 6.9 & 150 & 147 & 148 & 25.0 & 23.5 & 24.0 \\
\hline 08-09-00 & 8.5 & 5.2 & 7.8 & nd & nd & 7.1 & 6.9 & 152 & 149 & 150 & 25.0 & 25.0 & 25.0 \\
\hline $08-10-00$ & 8.2 & 5.2 & 7.8 & nd & nd & 7.1 & 6.9 & 154 & 149 & 151 & 26.0 & 24.5 & 25.0 \\
\hline $08-11-00$ & 8.4 & 6.6 & 7.7 & nd & nd & 7.2 & 7.0 & 154 & 148 & 150 & 26.0 & 25.0 & 25.5 \\
\hline $08-12-00$ & 8.5 & 6.8 & 7.9 & nd & nd & 7.2 & 6.9 & 149 & 142 & 146 & 25.0 & 24.0 & 24.5 \\
\hline $08-13-00$ & 8.3 & 7.3 & 7.9 & nd & nd & 7.0 & 6.9 & 144 & 141 & 142 & 24.0 & 21.5 & 22.5 \\
\hline $08-14-00$ & 8.7 & 7.6 & 8.3 & nd & nd & 7.0 & 6.9 & 149 & 144 & 147 & 21.5 & 20.5 & 21.0 \\
\hline $08-15-00$ & 9.6 & 6.9 & 8.2 & nd & nd & 7.0 & 6.7 & 155 & 148 & 152 & 21.0 & 20.0 & 20.5 \\
\hline $08-16-00$ & 9.0 & 7.9 & 8.5 & nd & nd & 7.0 & 6.8 & 155 & 152 & 153 & 21.0 & 21.0 & 21.0 \\
\hline $08-17-00$ & 8.8 & 8.0 & 8.4 & nd & nd & 7.0 & 6.8 & 154 & 147 & 150 & 21.5 & 20.5 & 21.0 \\
\hline $08-18-00$ & 9.1 & 8.1 & 8.6 & nd & nd & 7.0 & 6.8 & 148 & 142 & 145 & 21.0 & 20.0 & 20.5 \\
\hline 08-19-00 & 9.0 & 8.3 & 8.6 & nd & nd & 7.0 & 6.8 & 145 & 140 & 141 & 20.5 & 19.0 & 20.0 \\
\hline $08-20-00$ & 9.3 & 8.5 & 8.9 & nd & nd & 7.1 & 6.9 & 155 & 145 & 149 & 21.0 & 20.0 & 20.5 \\
\hline $08-21-00$ & 9.5 & 8.2 & 9.2 & nd & nd & 7.1 & 7.0 & 155 & 152 & 153 & 20.5 & 20.0 & 20.0 \\
\hline $08-22-00$ & 9.7 & 8.8 & 9.3 & .08 & -.08 & 7.1 & 6.9 & 159 & 154 & 156 & 20.5 & 20.0 & 20.0 \\
\hline $08-23-00$ & 9.7 & 8.9 & 9.3 & .21 & -.10 & 7.2 & 6.9 & 164 & 155 & 159 & 21.0 & 20.0 & 20.5 \\
\hline $08-24-00$ & 9.4 & 8.8 & 9.1 & .10 & -.07 & 7.1 & 7.0 & 161 & 159 & 160 & 21.0 & 20.0 & 20.5 \\
\hline $08-25-00$ & 9.7 & 8.7 & 9.2 & .07 & -.19 & 7.2 & 7.0 & 165 & 158 & 161 & 22.5 & 20.5 & 21.5 \\
\hline $08-26-00$ & 9.4 & 8.6 & 8.9 & .08 & -.09 & 7.2 & 7.0 & 163 & 157 & 159 & 23.0 & 21.5 & 22.0 \\
\hline $08-27-00$ & 9.6 & 8.6 & 9.0 & .12 & -.08 & 7.2 & 6.9 & 166 & 159 & 161 & 23.0 & 22.0 & 22.5 \\
\hline $08-28-00$ & 9.1 & 7.0 & 8.5 & nd & nd & 7.2 & 6.8 & 169 & 166 & 167 & 23.0 & 22.5 & 22.5 \\
\hline 08-29-00 & 9.5 & 8.0 & 8.7 & .12 & -.14 & 7.3 & 6.7 & 176 & 167 & 171 & 23.0 & 22.0 & 22.0 \\
\hline $08-30-00$ & 9.5 & 8.4 & 9.0 & .08 & -.24 & 7.3 & 7.1 & 177 & 170 & 173 & 23.0 & 22.0 & 22.0 \\
\hline $08-31-00$ & 9.4 & 8.2 & 8.8 & .11 & -.10 & 7.1 & 7.0 & 177 & 146 & 160 & 22.5 & 21.5 & 22.0 \\
\hline 09-01-00 & 9.1 & 8.2 & 8.6 & .06 & nd & 7.1 & 6.9 & 161 & 146 & 153 & 24.0 & 22.5 & 23.0 \\
\hline 09-02-00 & 8.7 & 7.6 & 8.0 & nd & nd & 7.1 & 6.9 & 173 & 161 & 167 & 24.5 & 24.0 & 24.0 \\
\hline 09-03-00 & 8.2 & 7.2 & 7.6 & nd & nd & 7.0 & 6.9 & 177 & 169 & 174 & 24.0 & 23.5 & 24.0 \\
\hline 09-04-00 & 8.7 & 7.0 & 7.6 & nd & -.12 & 7.2 & 6.9 & 177 & 171 & 174 & 23.5 & 23.0 & 23.5 \\
\hline 09-05-00 & 8.8 & 7.8 & 8.4 & .13 & -.06 & 7.3 & 7.1 & 182 & 174 & 176 & 23.5 & 22.0 & 23.0 \\
\hline 09-06-00 & 9.8 & 8.2 & 8.7 & .11 & -.07 & 7.3 & 7.1 & 185 & 181 & 183 & 22.0 & 20.0 & 20.5 \\
\hline 09-07-00 & 10.2 & 9.2 & 9.7 & .19 & -.06 & 7.3 & 7.1 & 186 & 185 & 185 & 20.0 & 18.5 & 19.5 \\
\hline 09-08-00 & 10.5 & 9.7 & 10.1 & .19 & -.09 & 7.3 & 7.2 & 187 & 183 & 185 & 19.5 & 18.5 & 19.0 \\
\hline 09-09-00 & 10.3 & 9.7 & 9.9 & nd & nd & 7.3 & 7.2 & 186 & 184 & 184 & 20.0 & 19.5 & 19.5 \\
\hline $09-10-00$ & 10.0 & 8.2 & 9.5 & nd & -.08 & 7.3 & 7.1 & 186 & 183 & 185 & 21.0 & 20.0 & 20.5 \\
\hline 09-11-00 & 10.1 & 9.1 & 9.6 & .13 & -.08 & 7.5 & 7.2 & 190 & 177 & 184 & 22.0 & 21.0 & 21.5 \\
\hline $09-12-00$ & 11.6 & 9.3 & 10.3 & .39 & -.10 & 8.2 & 7.4 & 188 & 184 & 186 & 22.5 & 21.5 & 22.0 \\
\hline 09-13-00 & 11.5 & 9.7 & 10.6 & nd & nd & 8.4 & 7.9 & 188 & 186 & 186 & 22.5 & 22.0 & 22.5 \\
\hline 09-14-00 & 12.8 & 9.3 & 11.7 & .45 & -.13 & 8.9 & 8.4 & 192 & 187 & 190 & 22.5 & 22.0 & 22.0 \\
\hline $09-15-00$ & 11.8 & 7.9 & 10.3 & .14 & -.25 & 8.7 & 7.4 & 190 & 173 & 184 & 22.5 & 21.0 & 21.5 \\
\hline
\end{tabular}


Appendix 3. Continuous water-quality monitor data and estimated maximum rates of instream metabolic processes at station 01126720 , Quinebaug River near Packer, Conn.-Continued

$\left[\mathrm{mg} / \mathrm{L}\right.$, milligrams per liter; $\mathrm{P}_{\max }$ (maximum rate of productivity) and $\mathrm{R}_{\max }$ (maximum rate of respiration) in grams of oxygen per cubic meter per hour $\left(\mathrm{g} \mathrm{O}_{2} / \mathrm{m}^{3} / \mathrm{hr}\right.$ ) estimated from diel changes in dissolved oxygen concentrations; $\mu \mathrm{S} / \mathrm{cm}$, microsiemens per centimeter at 25 degrees Celsius; --, data not available due to partial record; nd, not determined due to equipment malfunction or changes in dissolved oxygen concentration that result from rapid changes in streamflow]

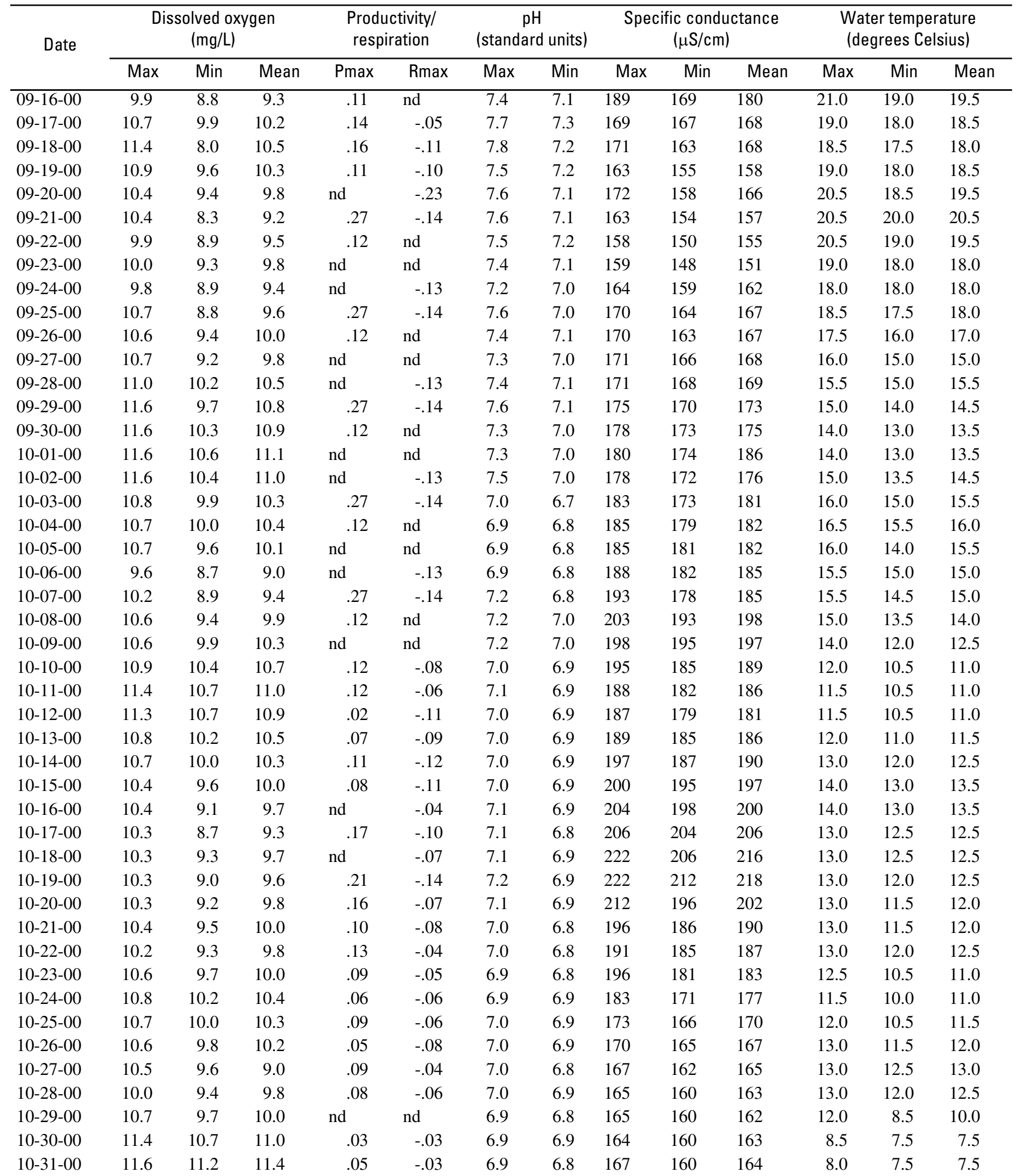


Appendix 3. Continuous water-quality monitor data and estimated maximum rates of instream metabolic processes at station 01126720 , Quinebaug River near Packer, Conn.-Continued

[mg/L, milligrams per liter; $\mathrm{P}_{\max }$ (maximum rate of productivity) and $\mathrm{R}_{\max }$ (maximum rate of respiration) in grams of oxygen per cubic meter per hour $\left(\mathrm{g} \mathrm{O}_{2} / \mathrm{m}^{3} / \mathrm{hr}\right.$ ) estimated from diel changes in dissolved oxygen concentrations; $\mu \mathrm{S} / \mathrm{cm}$, microsiemens per centimeter at 25 degrees Celsius; --, data not available due to partial record; nd, not determined due to equipment malfunction or changes in dissolved oxygen concentration that result from rapid changes in streamflow]

\begin{tabular}{|c|c|c|c|c|c|c|c|c|c|c|c|c|c|}
\hline \multirow{2}{*}{ Date } & \multicolumn{3}{|c|}{$\begin{array}{l}\text { Dissolved oxygen } \\
\text { (mg/L) }\end{array}$} & \multicolumn{2}{|c|}{$\begin{array}{l}\text { Productivity/ } \\
\text { respiration }\end{array}$} & \multicolumn{2}{|c|}{$\begin{array}{c}\mathrm{pH} \\
\text { (standard units) }\end{array}$} & \multicolumn{3}{|c|}{$\begin{array}{l}\text { Specific conductance } \\
(\mu \mathrm{S} / \mathrm{cm})\end{array}$} & \multicolumn{3}{|c|}{$\begin{array}{l}\text { Water temperature } \\
\text { (degrees Celsius) }\end{array}$} \\
\hline & Max & Min & Mean & Pmax & Rmax & Max & Min & Max & Min & Mean & Max & Min & Mean \\
\hline $11-01-00$ & 11.6 & 10.4 & 11.0 & nd & nd & 6.9 & 6.8 & 165 & 160 & 162 & 8.5 & 8.0 & 8.0 \\
\hline $11-02-00$ & 10.6 & 10.2 & 10.5 & nd & nd & 6.9 & 6.8 & 164 & 161 & 163 & 9.0 & 8.0 & 8.5 \\
\hline $11-03-00$ & 10.4 & 10.1 & 10.3 & nd & nd & 6.9 & 6.8 & 166 & 160 & 163 & 8.0 & 8.5 & 9.0 \\
\hline $11-04-00$ & 10.5 & 10.1 & 10.3 & nd & nd & 6.9 & 6.8 & 170 & 162 & 167 & 9.5 & 9.0 & 9.5 \\
\hline $11-05-00$ & 10.4 & 9.9 & 10.2 & nd & nd & 6.9 & 6.8 & 171 & 164 & 169 & 9.5 & 9.0 & 9.5 \\
\hline $11-06-00$ & 10.4 & 9.9 & 10.2 & .06 & -.02 & 6.9 & 6.8 & 172 & 168 & 170 & 8.0 & 8.5 & 9.0 \\
\hline $11-07-00$ & 10.9 & 10.2 & 10.6 & .06 & -.07 & 6.9 & 6.8 & 169 & 167 & 169 & 8.5 & 8.0 & 8.5 \\
\hline $11-08-00$ & 10.9 & 10.4 & 10.7 & nd & -.04 & 6.9 & 6.8 & 171 & 167 & 169 & 8.5 & 8.0 & 8.5 \\
\hline $11-09-00$ & 11.1 & 10.5 & 10.8 & nd & -.09 & 6.9 & 6.8 & 171 & 167 & 169 & 9.0 & 8.5 & 8.5 \\
\hline $11-10-00$ & 10.8 & 9.2 & 10.2 & .08 & -.06 & 6.9 & 6.6 & 172 & 161 & 169 & 9.5 & 9.0 & 9.5 \\
\hline $11-11-00$ & 10.0 & 9.4 & 9.6 & .03 & -.04 & 6.7 & 6.6 & 166 & 149 & 159 & 9.5 & 9.5 & 9.5 \\
\hline $11-12-00$ & 10.4 & 9.7 & 9.9 & .10 & -.05 & 6.7 & 6.6 & 149 & 139 & 142 & 10.0 & 9.5 & 9.5 \\
\hline $11-13-00$ & 10.4 & 9.8 & 10.1 & .08 & -.06 & 6.7 & 6.6 & 145 & 142 & 144 & 9.5 & 9.0 & 9.5 \\
\hline $11-14-00$ & 10.3 & 9.9 & 10.1 & .07 & -.05 & 6.6 & 6.6 & 145 & 142 & 144 & 9.0 & 9.0 & 9.0 \\
\hline $11-15-00$ & 10.7 & 9.9 & 10.2 & .08 & -.05 & 6.7 & 6.6 & 145 & 140 & 143 & 9.0 & 8.0 & 8.5 \\
\hline $11-16-00$ & 11.4 & 10.4 & 10.8 & nd & nd & 6.8 & 6.6 & 146 & 139 & 142 & 8.0 & 7.5 & 7.5 \\
\hline $11-17-00$ & 11.4 & 10.8 & 11.0 & nd & -.09 & 6.9 & 6.8 & 147 & 136 & 142 & 8.0 & 7.5 & 7.5 \\
\hline $11-18-00$ & 11.6 & 10.9 & 11.1 & .08 & -.06 & 6.9 & 6.8 & 150 & 140 & 145 & 8.0 & 6.5 & 7.0 \\
\hline $11-19-00$ & 11.9 & 11.4 & 11.6 & .03 & -.04 & 6.8 & 6.8 & 150 & 143 & 146 & 6.5 & 6.0 & 6.0 \\
\hline $11-20-00$ & 12.2 & 11.8 & 12.0 & nd & nd & 6.9 & 6.8 & 149 & 142 & 146 & 6.0 & 5.0 & 5.5 \\
\hline $11-21-00$ & 12.4 & 12.0 & 12.2 & nd & nd & 6.8 & 6.8 & 151 & 144 & 148 & 5.0 & 4.5 & 4.5 \\
\hline $11-22-00$ & 12.6 & 12.3 & 12.5 & nd & nd & 6.8 & 6.8 & 151 & 148 & 150 & 4.5 & 3.5 & 4.0 \\
\hline $11-23-00$ & 13.2 & 12.5 & 13.0 & nd & nd & 6.8 & 6.8 & 154 & 148 & 152 & 3.5 & 2.0 & 2.5 \\
\hline $11-24-00$ & 13.7 & 13.2 & 13.6 & nd & nd & 6.8 & 6.8 & 156 & 149 & 154 & 2.0 & 1.0 & 1.5 \\
\hline $11-25-00$ & 14.3 & 13.7 & 14.1 & nd & nd & 6.8 & 6.8 & 156 & 155 & 155 & 1.0 & .5 & 1.0 \\
\hline $11-26-00$ & 14.5 & 13.9 & 14.3 & nd & nd & 6.8 & 6.8 & 156 & 152 & 154 & 2.0 & .5 & 1.0 \\
\hline $11-27-00$ & 13.9 & 12.9 & 13.3 & nd & nd & 6.8 & 6.7 & 153 & 138 & 147 & 3.5 & 2.0 & 3.0 \\
\hline $11-28-00$ & 13.2 & 12.6 & 12.8 & nd & nd & 6.8 & 6.7 & 143 & 134 & 137 & 4.5 & 3.5 & 4.0 \\
\hline $11-29-00$ & 12.9 & 12.4 & 12.6 & nd & nd & 6.8 & 6.7 & 144 & 138 & 141 & 4.5 & 4.0 & 4.5 \\
\hline $11-30-00$ & 12.9 & 12.4 & 12.6 & nd & nd & 6.8 & 6.8 & 149 & 139 & 144 & 4.5 & 4.0 & 4.0 \\
\hline $12-01-00$ & 13.3 & 12.7 & 12.9 & nd & nd & 6.8 & 6.7 & 149 & 140 & 145 & 4.0 & 3.0 & 3.5 \\
\hline $12-02-00$ & 13.8 & 13.2 & 13.4 & nd & nd & 6.8 & 6.7 & 150 & 139 & 145 & 3.0 & 2.0 & 2.5 \\
\hline $12-03-00$ & 14.5 & 13.8 & 14.0 & nd & nd & 6.8 & 6.7 & 154 & 142 & 149 & 2.0 & 1.0 & 1.0 \\
\hline $12-04-00$ & 14.7 & 14.4 & 14.5 & nd & nd & 6.7 & 6.7 & 156 & 150 & 152 & 1.0 & .5 & .5 \\
\hline $12-05-00$ & 14.8 & 14.5 & 14.6 & nd & nd & 6.7 & 6.7 & 158 & 155 & 156 & .5 & .0 & .5 \\
\hline $12-06-00$ & 14.6 & 14.3 & 14.5 & nd & nd & 6.8 & 6.7 & -- & 158 & -- & .5 & .5 & .5 \\
\hline $05-03-01$ & 10.2 & -- & -- & .17 & -.21 & 7.4 & 7.0 & 167 & 161 & -- & 20.5 & -- & -- \\
\hline $05-04-01$ & 10.0 & 8.2 & 9.1 & .25 & -.30 & 7.4 & 7.0 & 169 & 156 & 164 & 21.5 & 19.5 & 20.5 \\
\hline $05-05-01$ & 9.8 & 7.7 & 8.6 & .22 & -.18 & 7.4 & 6.9 & 170 & 160 & 167 & 21.5 & 20.0 & 20.5 \\
\hline $05-06-01$ & 10.5 & 8.3 & 9.2 & .17 & -.22 & 7.4 & 7.1 & 166 & 161 & 164 & 20.0 & 18.0 & 18.5 \\
\hline 05-07-01 & 11.0 & 8.8 & 9.8 & .18 & -.21 & 7.4 & 7.1 & 166 & 161 & 163 & 18.0 & 16.0 & 16.5 \\
\hline $05-08-01$ & 11.0 & 9.1 & 10.0 & .15 & -.22 & 7.4 & 7.1 & 168 & 161 & 164 & 17.0 & 15.5 & 16.5 \\
\hline 05-09-01 & 10.9 & 9.0 & 9.9 & .16 & -.26 & 7.4 & 7.1 & 171 & 165 & 167 & 18.0 & 16.0 & 17.0 \\
\hline $05-10-01$ & 10.8 & 8.5 & 9.6 & .11 & -.25 & 7.4 & 7.0 & 172 & 164 & 168 & 19.0 & 17.5 & 18.0 \\
\hline $05-11-01$ & 10.6 & 8.4 & 9.3 & .12 & -.26 & 7.3 & 7.0 & 177 & 170 & 173 & 19.5 & 18.5 & 19.0 \\
\hline $05-12-01$ & 10.3 & 8.3 & 9.2 & .12 & -.22 & 7.3 & 7.1 & 184 & 167 & 175 & 21.0 & 19.5 & 20.0 \\
\hline
\end{tabular}


Appendix 3. Continuous water-quality monitor data and estimated maximum rates of instream metabolic processes at station 01126720 , Quinebaug River near Packer, Conn.-Continued

$\left[\mathrm{mg} / \mathrm{L}\right.$, milligrams per liter; $\mathrm{P}_{\max }$ (maximum rate of productivity) and $\mathrm{R}_{\max }$ (maximum rate of respiration) in grams of oxygen per cubic meter per hour $\left(\mathrm{g} \mathrm{O}_{2} / \mathrm{m}^{3} / \mathrm{hr}\right.$ ) estimated from diel changes in dissolved oxygen concentrations; $\mu \mathrm{S} / \mathrm{cm}$, microsiemens per centimeter at 25 degrees Celsius; --, data not available due to partial record; nd, not determined due to equipment malfunction or changes in dissolved oxygen concentration that result from rapid changes in streamflow]

\begin{tabular}{|c|c|c|c|c|c|c|c|c|c|c|c|c|c|}
\hline \multirow{2}{*}{ Date } & \multicolumn{3}{|c|}{$\begin{array}{l}\text { Dissolved oxygen } \\
\text { (mg/L) }\end{array}$} & \multicolumn{2}{|c|}{$\begin{array}{l}\text { Productivity/ } \\
\text { respiration }\end{array}$} & \multicolumn{2}{|c|}{$\begin{array}{c}\mathrm{pH} \\
\text { (standard units) }\end{array}$} & \multicolumn{3}{|c|}{$\begin{array}{l}\text { Specific conductance } \\
(\mu \mathrm{S} / \mathrm{cm})\end{array}$} & \multicolumn{3}{|c|}{$\begin{array}{l}\text { Water temperature } \\
\text { (degrees Celsius) }\end{array}$} \\
\hline & Max & Min & Mean & Pmax & Rmax & Max & Min & Max & Min & Mean & Max & Min & Mean \\
\hline $05-14-01$ & 10.2 & 8.4 & 9.5 & .12 & -.27 & 7.4 & 7.2 & 192 & 173 & 178 & 19.5 & 17.5 & 18.5 \\
\hline $05-15-01$ & 10.3 & 7.9 & 9.4 & .09 & nd & 7.4 & 7.2 & 196 & 182 & 188 & 17.5 & 16.0 & 17.0 \\
\hline $05-16-01$ & 10.3 & 9.2 & 9.8 & nd & nd & 7.3 & 6.9 & 184 & 173 & 180 & 16.0 & 14.5 & 15.5 \\
\hline $05-18-01$ & 11.0 & 9.5 & 10.2 & nd & nd & 7.3 & 7.0 & 190 & 182 & 187 & 15.0 & 14.5 & 15.0 \\
\hline 05-19-01 & 11.0 & 9.7 & 10.3 & .10 & -.11 & 7.3 & 7.1 & 189 & 174 & 183 & 17.0 & 14.5 & 15.5 \\
\hline $05-20-01$ & 11.0 & 9.8 & 10.4 & nd & -.23 & 7.3 & 7.2 & 194 & 177 & 183 & 18.0 & 17.0 & 17.5 \\
\hline $05-21-01$ & 10.8 & 9.5 & 10.0 & nd & nd & 7.4 & 7.1 & 201 & 177 & 190 & 18.5 & 17.5 & 18.0 \\
\hline $05-22-01$ & 10.1 & 7.9 & 9.1 & nd & nd & 7.2 & 6.8 & 193 & 175 & 179 & 18.0 & 17.0 & 17.5 \\
\hline $05-23-01$ & 8.6 & 7.8 & 8.1 & .09 & -.01 & 6.9 & 6.8 & 195 & 162 & 181 & 17.0 & 16.0 & 16.5 \\
\hline $05-27-01$ & 9.3 & 8.7 & 9.0 & .10 & -.08 & 7.0 & 6.8 & 151 & 133 & 146 & 18.0 & 16.5 & 17.0 \\
\hline $05-28-01$ & 9.0 & 8.5 & 8.8 & .06 & -.05 & 6.8 & 6.7 & 149 & 132 & 142 & 18.0 & 17.0 & 17.5 \\
\hline $05-29-01$ & 9.3 & 8.3 & 8.9 & .09 & -.09 & 6.9 & 6.7 & 148 & 138 & 145 & 18.0 & 16.5 & 17.5 \\
\hline $05-30-01$ & 9.4 & 8.5 & 8.9 & .09 & -.09 & 6.9 & 6.7 & 152 & 141 & 145 & 18.0 & 16.5 & 17.5 \\
\hline $05-31-01$ & 10.0 & 8.6 & 9.3 & .14 & -.13 & 7.0 & 6.8 & 157 & 147 & 149 & 17.5 & 15.5 & 16.5 \\
\hline 06-01-01 & 10.4 & 8.8 & 9.6 & .16 & -.21 & 7.1 & 6.8 & 161 & 148 & 153 & 18.0 & 15.5 & 17.0 \\
\hline 06-02-01 & 9.9 & 8.6 & 9.0 & .06 & -.04 & 7.0 & 6.7 & 162 & 124 & 142 & 18.0 & 16.5 & 17.0 \\
\hline 06-03-01 & 9.2 & 8.9 & 9.1 & .02 & -.05 & 6.7 & 6.7 & 131 & 106 & 115 & 17.5 & 16.0 & 17.0 \\
\hline 06-04-01 & 9.2 & 8.8 & 9.0 & .05 & -.05 & 6.8 & 6.7 & 132 & 113 & 123 & 18.0 & 17.0 & 17.5 \\
\hline $06-05-01$ & 9.4 & 8.9 & 9.1 & .07 & .08 & 6.8 & 6.7 & 143 & 130 & 137 & 19.0 & 17.0 & 18.0 \\
\hline $06-24-01$ & 7.7 & 7.3 & 7.5 & .05 & -.04 & 6.8 & 6.7 & 131 & 128 & 129 & 23.0 & 22.5 & 22.5 \\
\hline $06-25-01$ & 8.0 & 7.4 & 7.7 & .07 & -.08 & 6.8 & 6.7 & 135 & 131 & 132 & 24.0 & 22.0 & 23.0 \\
\hline $06-26-01$ & 7.8 & 7.2 & 7.5 & .09 & -.07 & 6.8 & 6.7 & 142 & 131 & 136 & 25.0 & 22.5 & 24.0 \\
\hline $06-27-01$ & -- & 6.9 & -- & nd & nd & -- & -- & -- & -- & -- & -- & 23.5 & -- \\
\hline
\end{tabular}


50 Nutrient Enrichment, Phytoplankton Algal Growth, and Rates of Metabolism in the Quinebaug River Basin, Conn.

Appendix 4 
Appendix 4. Continuous water-quality monitor data and estimated maximum rates of instream metabolic processes at station 01127000 , Quinebaug River at Jewett City, Conn.

[mg/L, milligrams per liter; $\mathrm{P}_{\max }$ (maximum rate of productivity) and $\mathrm{R}_{\max }$ (maximum rate of respiration) in grams of oxygen per cubic meter per hour $\left(\mathrm{g} \mathrm{O}_{2} / \mathrm{m}^{3} / \mathrm{hr}\right.$ ) estimated from diel changes in dissolved oxygen concentrations; $\mu \mathrm{S} / \mathrm{cm}$, microsiemens per centimeter at 25 degrees Celsius; --, data not available due to partial record; nd, not determined due to equipment malfunction or changes in dissolved oxygen concentration that result from rapid changes in streamflow]

\begin{tabular}{|c|c|c|c|c|c|c|c|c|c|c|c|c|c|}
\hline \multirow[t]{2}{*}{ Date } & \multicolumn{3}{|c|}{$\begin{array}{l}\text { Dissolved oxygen } \\
\text { (mg/L) }\end{array}$} & \multicolumn{2}{|c|}{$\begin{array}{l}\text { Productivity/ } \\
\text { respiration }\end{array}$} & \multicolumn{2}{|c|}{$\begin{array}{c}\mathrm{pH} \\
\text { (standard units) }\end{array}$} & \multicolumn{3}{|c|}{$\begin{array}{c}\text { Specific conductance } \\
(\mu \mathrm{S} / \mathrm{cm})\end{array}$} & \multicolumn{3}{|c|}{$\begin{array}{l}\text { Water temperature } \\
\text { (degrees Celsius) }\end{array}$} \\
\hline & Max & Min & Mean & Pmax & Rmax & Max & Min & Max & Min & Mean & Max & Min & Mean \\
\hline $06-02-00$ & -- & -- & -- & nd & nd & -- & -- & -- & -- & -- & 26.5 & -- & -- \\
\hline $06-03-00$ & -- & -- & -- & nd & nd & 7.1 & 6.7 & 114 & 107 & 111 & 22.5 & 20.5 & 21.5 \\
\hline $06-04-00$ & -- & -- & -- & nd & nd & 6.9 & 6.6 & 111 & 107 & 109 & 21.5 & 20.5 & 21.0 \\
\hline $06-05-00$ & -- & -- & -- & nd & nd & 7.0 & 6.6 & 111 & 106 & 109 & 21.5 & 20.5 & 21.0 \\
\hline $06-06-00$ & --- & -- & -- & nd & nd & 6.7 & 6.6 & 115 & 108 & 111 & 20.5 & 18.0 & 19.0 \\
\hline $06-07-00$ & -- & -- & -- & nd & nd & 6.8 & 6.7 & 114 & 96 & 108 & 18.0 & 16.0 & 16.5 \\
\hline $06-08-00$ & -- & -- & -- & nd & nd & 6.7 & 6.7 & 100 & 93 & 97 & 16.5 & 15.5 & 16.0 \\
\hline $06-09-00$ & -- & -- & -- & nd & nd & 6.8 & 6.7 & 101 & 98 & 99 & 18.0 & 16.5 & 17.0 \\
\hline $06-10-00$ & -- & -- & -- & nd & nd & 6.7 & 6.7 & 101 & 99 & 100 & 20.0 & 18.0 & 19.0 \\
\hline $06-11-00$ & -- & -- & -- & nd & nd & 6.7 & 6.6 & 100 & 95 & 98 & 22.0 & 20.0 & 21.0 \\
\hline $06-12-00$ & --- & -- & -- & nd & nd & 6.7 & 6.6 & 98 & 94 & 97 & 21.5 & 19.0 & 20.5 \\
\hline $06-13-00$ & -- & -- & -- & nd & nd & 6.7 & 6.6 & 96 & 94 & 95 & 19.0 & 18.0 & 18.5 \\
\hline $06-14-00$ & -- & -- & -- & nd & nd & 6.7 & 6.6 & 98 & 94 & 95 & 18.0 & 18.0 & 18.0 \\
\hline $06-15-00$ & -- & -- & -- & nd & nd & 6.6 & 6.6 & 103 & 97 & 100 & 18.0 & 17.5 & 17.5 \\
\hline $06-16-00$ & 9.2 & 8.9 & 9.1 & nd & nd & 6.6 & 6.3 & 105 & 101 & 103 & 19.5 & 17.5 & 18.0 \\
\hline $06-17-00$ & 9.3 & 8.7 & 9.0 & nd & nd & 6.7 & 6.5 & 106 & 102 & 104 & 22.0 & 19.5 & 20.5 \\
\hline $06-18-00$ & 9.0 & 8.2 & 8.6 & nd & nd & 6.7 & 6.6 & 108 & 104 & 107 & 22.5 & 21.5 & 22.0 \\
\hline 06-19-00 & 8.7 & 8.2 & 8.4 & nd & nd & 6.7 & 6.6 & 110 & 106 & 108 & 21.5 & 21.0 & 21.5 \\
\hline $06-20-00$ & 9.0 & 8.2 & 8.5 & nd & nd & 6.8 & 6.6 & 112 & 108 & 110 & 22.5 & 20.5 & 21.5 \\
\hline $06-21-00$ & 9.0 & 8.1 & 8.6 & nd & nd & 6.8 & 6.6 & 114 & 110 & 112 & 22.0 & 21.0 & 21.5 \\
\hline $06-22-00$ & 8.7 & 8.1 & 8.4 & nd & nd & 6.8 & 6.7 & 116 & 113 & 115 & 22.5 & 21.5 & 22.0 \\
\hline $06-23-00$ & 9.3 & 7.9 & 8.5 & nd & nd & 7.1 & 6.7 & 118 & 114 & 116 & 24.5 & 22.0 & 23.0 \\
\hline $06-24-00$ & 9.0 & 7.7 & 8.2 & nd & nd & 7.0 & 6.6 & 123 & 117 & 120 & 24.0 & 22.5 & 23.0 \\
\hline $06-25-00$ & 8.8 & 6.8 & 8.1 & nd & nd & 7.0 & 6.4 & 131 & 113 & 124 & 24.5 & 23.0 & 23.5 \\
\hline $06-26-00$ & 9.1 & 6.8 & 8.0 & nd & nd & 6.9 & 6.5 & 135 & 117 & 127 & 26.0 & 24.0 & 24.5 \\
\hline $06-27-00$ & 8.7 & 6.6 & 8.1 & nd & nd & 7.3 & 6.7 & 130 & 121 & 125 & 25.5 & 24.0 & 25.0 \\
\hline $06-28-00$ & 8.9 & 6.4 & 8.0 & nd & nd & 7.3 & 6.8 & 126 & 108 & 122 & 27.5 & 24.5 & 25.0 \\
\hline $06-29-00$ & 8.1 & 7.3 & 7.7 & nd & nd & 7.0 & 6.8 & 135 & 124 & 129 & 25.0 & 24.5 & 24.5 \\
\hline $06-30-00$ & 9.1 & 7.4 & 8.3 & nd & nd & 7.5 & 6.6 & 135 & 107 & 127 & 25.0 & 23.5 & 24.0 \\
\hline $07-01-00$ & 10.1 & 6.6 & 8.4 & nd & nd & 8.5 & 6.5 & 130 & 113 & 122 & 25.5 & 22.5 & 24.0 \\
\hline $07-02-00$ & 9.6 & 5.2 & 8.4 & nd & nd & 8.1 & 6.7 & 131 & 114 & 123 & 26.0 & 22.5 & 23.5 \\
\hline $07-03-00$ & 9.5 & 5.3 & 8.2 & nd & nd & 7.9 & 6.7 & 129 & 113 & 123 & 26.0 & 22.5 & 24.0 \\
\hline 07-04-00 & 9.2 & 6.3 & 7.7 & nd & nd & 8.0 & 6.7 & 133 & 116 & 125 & 26.5 & 23.5 & 24.5 \\
\hline $07-05-00$ & 10.3 & 5.5 & 8.1 & nd & nd & 8.5 & 6.8 & 138 & 119 & 129 & 27.0 & 24.0 & 25.5 \\
\hline $07-06-00$ & 9.1 & 6.4 & 7.9 & nd & nd & 7.6 & 6.7 & 137 & 123 & 132 & 28.0 & 24.0 & 25.5 \\
\hline $07-07-00$ & 9.9 & 6.5 & 8.1 & nd & nd & 8.4 & 6.7 & 140 & 128 & 134 & 26.5 & 23.0 & 24.5 \\
\hline $07-08-00$ & 9.3 & 6.3 & 7.6 & nd & nd & 7.6 & 6.7 & 141 & 132 & 137 & 25.5 & 22.0 & 23.5 \\
\hline 07-09-00 & 9.0 & 6.0 & 7.4 & nd & nd & 7.2 & 6.6 & 149 & 133 & 144 & 25.0 & 22.5 & 23.5 \\
\hline $07-10-00$ & 8.9 & 6.2 & 7.5 & nd & nd & 7.2 & 6.6 & 148 & 139 & 143 & 25.5 & 22.5 & 23.5 \\
\hline $07-11-00$ & 9.5 & 5.8 & 7.4 & nd & nd & 8.1 & 6.6 & 150 & 139 & 144 & 25.5 & 22.0 & 23.5 \\
\hline $07-12-00$ & 9.2 & 5.6 & 7.1 & nd & nd & 7.9 & 6.7 & 153 & 141 & 147 & 26.0 & 22.0 & 24.0 \\
\hline $07-13-00$ & 8.8 & 5.4 & 6.9 & nd & nd & 7.5 & 6.7 & 153 & 144 & 148 & 26.5 & 22.5 & 24.0 \\
\hline $07-14-00$ & -- & -- & -- & nd & nd & -- & 6.7 & -- & 145 & -- & 30.0 & 21.5 & 24.0 \\
\hline $07-15-00$ & -- & -- & -- & nd & nd & -- & -- & 155 & -- & -- & 24.5 & 21.5 & 23.0 \\
\hline $07-16-00$ & -- & -- & -- & nd & nd & -- & -- & -- & 70 & -- & 25.0 & 19.5 & 23.0 \\
\hline $07-17-00$ & -- & -- & -- & nd & nd & -- & -- & 153 & -- & -- & 28.0 & 21.5 & 24.5 \\
\hline
\end{tabular}


Appendix 4. Continuous water-quality monitor data and estimated maximum rates of instream metabolic processes at station 01127000 Quinebaug River at Jewett City, Conn.-Continued

[mg/L, milligrams per liter; $\mathrm{P}_{\max }$ (maximum rate of productivity) and $\mathrm{R}_{\max }$ (maximum rate of respiration) in grams of oxygen per cubic meter per hour $\left(\mathrm{g} \mathrm{O}_{2} / \mathrm{m}^{3} / \mathrm{hr}\right.$ ) estimated from diel changes in dissolved oxygen concentrations; $\mu \mathrm{S} / \mathrm{cm}$, microsiemens per centimeter at 25 degrees Celsius; --, data not available due to partial record; nd, not determined due to equipment malfunction or changes in dissolved oxygen concentration that result from rapid changes in streamflow]

\begin{tabular}{|c|c|c|c|c|c|c|c|c|c|c|c|c|c|}
\hline \multirow{2}{*}{ Date } & \multicolumn{3}{|c|}{$\begin{array}{l}\text { Dissolved oxygen } \\
(\mathrm{mg} / \mathrm{L})\end{array}$} & \multicolumn{2}{|c|}{$\begin{array}{l}\text { Productivity/ } \\
\text { respiration }\end{array}$} & \multicolumn{2}{|c|}{$\begin{array}{c}\mathrm{pH} \\
\text { (standard units) }\end{array}$} & \multicolumn{3}{|c|}{$\begin{array}{l}\text { Specific conductance } \\
(\mu \mathrm{S} / \mathrm{cm})\end{array}$} & \multicolumn{3}{|c|}{$\begin{array}{l}\text { Water temperature } \\
\text { (degrees Celsius) }\end{array}$} \\
\hline & Max & Min & Mean & Pmax & Rmax & Max & Min & Max & Min & Mean & Max & Min & Mean \\
\hline $07-18-00$ & -- & -- & -- & nd & nd & -- & -- & -- & 65 & -- & 26.0 & 23.0 & 24.5 \\
\hline 07-19-00 & -- & -- & -- & nd & nd & -- & -- & -- & -- & -- & 24.5 & 22.0 & 23.5 \\
\hline $07-20-00$ & -- & -- & -- & nd & nd & -- & -- & -- & -- & -- & 25.0 & 21.5 & 23.0 \\
\hline $07-21-00$ & 9.9 & -- & -- & nd & nd & 6.9 & -- & 151 & 138 & 145 & -- & 21.0 & -- \\
\hline $07-22-00$ & 11.3 & 7.1 & 9.5 & nd & nd & 7.1 & 6.4 & 156 & 143 & 149 & 25.5 & 22.5 & 23.5 \\
\hline $07-23-00$ & 14.1 & 8.5 & 10.8 & nd & nd & 8.4 & 6.5 & 160 & 147 & 154 & 25.0 & 22.0 & 23.5 \\
\hline $07-24-00$ & 14.4 & 8.9 & 12.3 & nd & nd & 8.9 & 6.8 & 164 & 151 & 157 & 26.0 & 23.0 & 24.0 \\
\hline $07-25-00$ & 14.6 & 10.4 & 12.6 & nd & nd & 8.9 & 7.1 & 164 & 156 & 161 & 24.0 & 22.5 & 23.0 \\
\hline $07-26-00$ & 14.1 & 9.9 & 11.5 & nd & nd & 8.5 & 7.0 & 165 & 142 & 154 & 23.5 & 22.0 & 22.5 \\
\hline $07-27-00$ & 12.4 & 9.6 & 10.9 & nd & nd & 7.3 & 6.6 & 153 & 117 & 137 & 22.5 & 21.5 & 22.0 \\
\hline $07-28-00$ & 11.1 & 9.7 & 10.4 & nd & nd & 6.7 & 6.6 & 155 & 121 & 142 & 22.0 & 21.0 & 21.5 \\
\hline $07-29-00$ & 11.4 & 10.0 & 10.9 & nd & nd & 6.7 & 6.6 & 159 & 153 & 156 & 21.0 & 20.5 & 20.5 \\
\hline $07-30-00$ & 12.8 & 11.3 & 12.0 & nd & nd & 7.1 & 6.7 & 160 & 140 & 154 & 22.0 & 21.0 & 21.5 \\
\hline $07-31-00$ & 11.8 & 11.2 & 11.5 & nd & nd & 6.9 & 6.7 & 142 & 124 & 132 & 21.5 & 21.5 & 21.5 \\
\hline 08-01-00 & 11.3 & 10.8 & 11.1 & nd & nd & 6.7 & 6.6 & 130 & 120 & 124 & 21.5 & 21.0 & 21.0 \\
\hline $08-02-00$ & 11.4 & 10.2 & 10.7 & nd & nd & 6.7 & 6.5 & 127 & 102 & 117 & 22.0 & 21.0 & 21.5 \\
\hline $08-03-00$ & 10.6 & 9.8 & 10.2 & nd & nd & 6.7 & 6.5 & 121 & 93 & 116 & 23.0 & 21.5 & 22.0 \\
\hline $08-04-00$ & 10.4 & 8.6 & 9.6 & nd & nd & 6.9 & 6.3 & 119 & 92 & 114 & 24.0 & 22.5 & 23.0 \\
\hline $08-05-00$ & 9.2 & 7.4 & 8.3 & nd & nd & 7.0 & 6.5 & 129 & 95 & 114 & 25.0 & 22.5 & 23.5 \\
\hline 08-06-00 & -- & -- & -- & nd & nd & 6.8 & 6.5 & 129 & 104 & 117 & 24.5 & 23.0 & 23.5 \\
\hline 08-07-00 & -- & -- & -- & nd & nd & 6.8 & 6.3 & 133 & 101 & 118 & 24.5 & 23.0 & 23.5 \\
\hline 08-08-00 & -- & -- & -- & nd & nd & 6.9 & 6.5 & 131 & 105 & 117 & 26.5 & 23.5 & 24.5 \\
\hline 08-09-00 & -- & -- & -- & nd & nd & 6.9 & 6.6 & 137 & 113 & 125 & 26.0 & 24.0 & 24.5 \\
\hline $08-10-00$ & -- & -- & -- & nd & nd & 7.8 & 6.5 & 134 & 90 & 114 & 27.0 & 24.0 & 25.5 \\
\hline $08-11-00$ & -- & -- & -- & nd & nd & 7.1 & 6.6 & 134 & 106 & 121 & 27.5 & 25.0 & 26.0 \\
\hline $08-12-00$ & -- & -- & -- & nd & nd & 7.2 & 6.6 & 138 & 113 & 123 & 25.5 & 23.5 & 24.5 \\
\hline $08-13-00$ & -- & -- & -- & nd & nd & 6.9 & 6.6 & 140 & 114 & 126 & 24.0 & 22.5 & 23.5 \\
\hline $08-14-00$ & -- & -- & -- & nd & nd & 6.8 & 6.7 & 139 & 116 & 129 & 23.0 & 22.0 & 22.5 \\
\hline $08-15-00$ & -- & -- & -- & nd & nd & 6.9 & 6.6 & 136 & 116 & 124 & 23.0 & 21.5 & 22.0 \\
\hline $08-16-00$ & 9.4 & 8.1 & -- & nd & nd & 7.0 & 6.5 & 136 & 95 & 114 & 24.0 & 21.5 & 22.5 \\
\hline $08-17-00$ & 9.6 & 7.6 & 8.8 & nd & nd & 7.3 & 6.9 & 138 & 113 & 127 & 22.5 & 20.5 & 21.5 \\
\hline $08-18-00$ & 11.4 & 7.5 & 8.3 & nd & nd & 7.2 & 6.9 & 143 & 119 & 133 & 21.5 & 20.5 & 21.0 \\
\hline 08-19-00 & -- & -- & -- & nd & nd & 7.4 & 6.9 & 145 & 128 & 137 & 22.5 & 20.0 & 21.5 \\
\hline $08-20-00$ & -- & -- & -- & nd & nd & 7.4 & 6.8 & 142 & 127 & 136 & 24.0 & 20.5 & 21.5 \\
\hline $08-21-00$ & -- & -- & -- & nd & nd & 7.8 & 6.8 & 141 & 125 & 136 & 23.5 & 19.0 & 21.0 \\
\hline $08-22-00$ & -- & -- & -- & nd & nd & 7.5 & 6.8 & 144 & 131 & 138 & 22.5 & 19.5 & 21.0 \\
\hline $08-23-00$ & -- & -- & -- & nd & nd & 7.3 & 6.6 & 146 & 134 & 140 & 21.5 & 19.0 & 20.0 \\
\hline $08-24-00$ & -- & -- & -- & nd & nd & 7.3 & 6.6 & 145 & 132 & 140 & 24.5 & 20.0 & 21.5 \\
\hline $08-25-00$ & -- & -- & -- & nd & nd & 8.0 & 6.7 & 152 & 135 & 144 & 25.5 & 20.5 & 22.5 \\
\hline $08-26-00$ & -- & -- & -- & nd & nd & 7.8 & 6.6 & 153 & 138 & 146 & 24.5 & 21.0 & 22.0 \\
\hline $08-27-00$ & -- & -- & -- & nd & nd & 7.8 & 6.6 & 157 & 140 & 149 & 24.0 & 20.5 & 21.5 \\
\hline $08-28-00$ & -- & -- & -- & nd & nd & 7.3 & 6.5 & 153 & 143 & 147 & 24.5 & 22.0 & 23.0 \\
\hline 08-29-00 & -- & -- & -- & nd & nd & 8.3 & 6.6 & 158 & 145 & 149 & 26.0 & 22.0 & 23.0 \\
\hline $08-30-00$ & 10.3 & -- & -- & nd & nd & 8.0 & 6.5 & 161 & 145 & 155 & 24.0 & 21.5 & 22.5 \\
\hline $08-31-00$ & 11.0 & 4.1 & 8.1 & nd & nd & 7.6 & 6.8 & 166 & 147 & 158 & 24.5 & 22.5 & 23.0 \\
\hline 09-01-00 & 11.2 & 5.8 & 8.2 & nd & nd & 7.4 & 6.7 & 169 & 153 & 160 & 25.5 & 22.5 & 23.0 \\
\hline
\end{tabular}


Appendix 4. Continuous water-quality monitor data and estimated maximum rates of instream metabolic processes at station 01127000 , Quinebaug River at Jewett City, Conn.-Continued

$\left[\mathrm{mg} / \mathrm{L}\right.$, milligrams per liter; $\mathrm{P}_{\max }$ (maximum rate of productivity) and $\mathrm{R}_{\max }$ (maximum rate of respiration) in grams of oxygen per cubic meter per hour $\left(\mathrm{g} \mathrm{O}_{2} / \mathrm{m}^{3} / \mathrm{hr}\right.$ ) estimated from diel changes in dissolved oxygen concentrations; $\mu \mathrm{S} / \mathrm{cm}$, microsiemens per centimeter at 25 degrees Celsius; --, data not available due to partial record; nd, not determined due to equipment malfunction or changes in dissolved oxygen concentration that result from rapid changes in streamflow]

\begin{tabular}{|c|c|c|c|c|c|c|c|c|c|c|c|c|c|}
\hline \multirow[t]{2}{*}{ Date } & \multicolumn{3}{|c|}{$\begin{array}{l}\text { Dissolved oxygen } \\
\text { (mg/L) }\end{array}$} & \multicolumn{2}{|c|}{$\begin{array}{l}\text { Productivity/ } \\
\text { respiration }\end{array}$} & \multicolumn{2}{|c|}{$\begin{array}{c}\mathrm{pH} \\
\text { (standard units) }\end{array}$} & \multicolumn{3}{|c|}{$\begin{array}{c}\text { Specific conductance } \\
(\mu \mathrm{S} / \mathrm{cm})\end{array}$} & \multicolumn{3}{|c|}{$\begin{array}{l}\text { Water temperature } \\
\text { (degrees Celsius) }\end{array}$} \\
\hline & Max & Min & Mean & Pmax & Rmax & Max & Min & Max & Min & Mean & Max & Min & Mean \\
\hline $09-02-00$ & 10.0 & 4.4 & 7.6 & nd & nd & 7.1 & 6.6 & 162 & 111 & 142 & 24.5 & 23.0 & 24.0 \\
\hline 09-03-00 & 10.4 & 4.6 & 8.6 & nd & nd & 7.5 & 6.6 & 132 & 109 & 125 & 24.5 & 23.0 & 24.0 \\
\hline 09-04-00 & 10.7 & 4.4 & 8.9 & nd & nd & 7.6 & 6.8 & 133 & 124 & 128 & 25.5 & 23.5 & 24.0 \\
\hline $09-05-00$ & 12.1 & 6.1 & 10.1 & nd & nd & 7.8 & 6.8 & 153 & 124 & 134 & 23.5 & 21.0 & 22.5 \\
\hline 09-06-00 & 12.4 & 8.7 & 10.6 & nd & nd & 7.2 & 6.7 & 152 & 118 & 130 & 24.0 & 20.0 & 21.5 \\
\hline 09-07-00 & 12.8 & 9.1 & 10.6 & nd & nd & 7.4 & 6.8 & 140 & 123 & 133 & 23.0 & 19.5 & 21.0 \\
\hline 09-08-00 & 13.0 & 8.9 & 10.7 & nd & nd & 7.4 & 6.8 & 159 & 131 & 146 & 23.0 & 19.5 & 21.0 \\
\hline 09-09-00 & 12.8 & 7.3 & 10.0 & nd & nd & 7.3 & 6.7 & 151 & 130 & 142 & 22.5 & 20.0 & 21.0 \\
\hline $09-10-00$ & 12.2 & 7.5 & 10.5 & nd & nd & 7.3 & 6.7 & 155 & 117 & 129 & 24.5 & 21.0 & 22.0 \\
\hline $09-11-00$ & 12.3 & 7.4 & 10.5 & nd & nd & 7.4 & 6.8 & 157 & 113 & 126 & 24.0 & 21.0 & 22.0 \\
\hline $09-12-00$ & 11.8 & 8.5 & 10.1 & nd & nd & 7.3 & 6.8 & 142 & 115 & 125 & 24.0 & 21.5 & 22.5 \\
\hline $09-13-00$ & 11.6 & 8.4 & 9.6 & nd & nd & 7.3 & 6.7 & 139 & 115 & 127 & 24.5 & 22.0 & 23.0 \\
\hline 09-14-00 & 11.8 & 8.3 & 10.2 & nd & nd & 7.7 & 6.8 & 161 & 125 & 139 & 25.0 & 21.5 & 22.5 \\
\hline $09-15-00$ & 11.3 & 5.7 & 9.2 & nd & nd & 7.7 & 6.6 & 144 & 99 & 124 & 22.5 & 21.5 & 22.0 \\
\hline $09-16-00$ & 11.0 & 8.9 & 10.2 & nd & nd & 7.8 & 6.7 & 147 & 98 & 127 & 22.5 & 21.0 & 21.5 \\
\hline $09-17-00$ & 11.2 & 8.5 & 9.6 & nd & nd & 7.9 & 6.8 & 148 & 101 & 117 & 21.5 & 19.5 & 20.0 \\
\hline $09-18-00$ & 10.8 & 7.2 & 9.1 & nd & nd & 8.2 & 6.7 & 149 & 104 & 119 & 21.0 & 19.0 & 20.0 \\
\hline 09-19-00 & 10.1 & 6.8 & 8.1 & nd & nd & 8.2 & 6.7 & 151 & 111 & 127 & 20.5 & 19.5 & 20.0 \\
\hline $09-20-00$ & -- & -- & -- & nd & nd & 9.0 & 6.7 & 145 & 105 & 124 & 22.0 & 20.0 & 21.0 \\
\hline $09-21-00$ & -- & -- & -- & nd & nd & 8.9 & 7.0 & 142 & 110 & 128 & 21.0 & 20.0 & 20.5 \\
\hline $09-22-00$ & -- & -- & -- & nd & nd & 8.0 & 7.0 & 143 & 105 & 126 & 22.0 & 19.5 & 20.5 \\
\hline $09-23-00$ & -- & -- & -- & nd & nd & 7.7 & 6.9 & 141 & 111 & 122 & 20.0 & 19.0 & 19.5 \\
\hline $09-24-00$ & -- & -- & -- & nd & nd & 7.4 & 6.9 & 140 & 112 & 122 & 20.5 & 19.0 & 19.5 \\
\hline $09-25-00$ & -- & -- & -- & nd & nd & 7.7 & 7.0 & 141 & 115 & 124 & 20.0 & 18.0 & 19.0 \\
\hline $09-26-00$ & -- & -- & -- & nd & nd & 7.7 & 7.0 & 140 & 119 & 130 & 18.5 & 17.0 & 17.5 \\
\hline $09-27-00$ & -- & -- & -- & nd & nd & 7.7 & 6.9 & 149 & 119 & 132 & 19.5 & 16.0 & 17.0 \\
\hline $09-28-00$ & -- & -- & -- & nd & nd & 8.6 & 6.9 & 149 & 124 & 135 & 17.5 & 15.5 & 16.5 \\
\hline $09-29-00$ & -- & -- & -- & nd & nd & 8.1 & 7.0 & 154 & 128 & 139 & 18.0 & 14.5 & 16.0 \\
\hline $09-30-00$ & -- & -- & -- & nd & nd & 8.1 & 7.0 & 155 & 132 & 142 & 18.5 & 14.5 & 15.5 \\
\hline $10-01-00$ & 14.2 & 10.6 & 12.7 & nd & nd & 8.0 & 7.0 & 153 & 134 & 144 & 18.0 & 14.0 & 15.5 \\
\hline $10-02-00$ & 14.7 & 10.2 & 12.3 & nd & nd & 8.7 & 7.0 & 164 & 137 & 152 & 16.0 & 14.5 & 15.5 \\
\hline $10-03-00$ & 12.7 & 9.6 & 11.4 & nd & nd & 7.8 & 6.9 & 164 & 144 & 154 & 18.5 & 15.0 & 16.0 \\
\hline $10-04-00$ & 11.8 & 8.3 & 10.4 & nd & nd & 7.4 & 6.8 & 166 & 144 & 155 & 18.0 & 15.0 & 16.0 \\
\hline $10-05-00$ & 11.1 & 8.4 & 9.8 & nd & nd & 7.1 & 6.8 & 166 & 144 & 153 & 16.5 & 14.5 & 16.0 \\
\hline $10-06-00$ & 11.3 & 9.1 & 10.2 & nd & nd & 7.2 & 6.9 & 164 & 139 & 151 & 17.0 & 16.0 & 16.5 \\
\hline $10-07-00$ & 11.3 & 9.1 & 10.1 & nd & nd & 7.1 & 6.8 & 166 & 134 & 157 & 16.5 & 15.0 & 15.5 \\
\hline $10-08-00$ & 11.3 & 9.0 & 9.9 & nd & nd & 7.1 & 6.7 & 170 & 145 & 160 & 17.0 & 14.0 & 15.0 \\
\hline $10-09-00$ & 11.3 & 9.2 & 10.0 & nd & nd & 7.0 & 6.7 & 171 & 148 & 158 & 14.0 & 12.5 & 13.5 \\
\hline $10-10-00$ & 11.3 & 9.4 & 10.3 & nd & nd & 7.1 & 6.8 & 173 & 152 & 166 & 13.5 & 12.0 & 12.5 \\
\hline $10-11-00$ & 11.9 & 9.5 & 10.6 & nd & nd & 7.3 & 6.9 & 183 & 161 & 173 & 15.0 & 12.0 & 13.0 \\
\hline $10-12-00$ & 12.1 & 9.6 & 10.6 & nd & nd & 7.4 & 6.9 & 182 & 165 & 172 & 15.0 & 11.0 & 12.5 \\
\hline $10-13-00$ & 12.3 & 9.4 & 10.7 & nd & nd & 7.5 & 7.0 & 180 & 161 & 172 & 15.0 & 11.0 & 12.5 \\
\hline $10-14-00$ & 11.9 & 8.9 & 10.5 & nd & nd & 7.6 & 6.9 & 177 & 161 & 168 & 16.0 & 12.0 & 13.5 \\
\hline $10-15-00$ & 11.9 & 8.7 & 10.4 & nd & nd & 7.6 & 6.9 & 174 & 157 & 166 & 15.5 & 12.5 & 14.0 \\
\hline $10-16-00$ & 10.7 & 8.2 & 9.7 & nd & nd & 7.3 & 6.9 & 178 & 143 & 166 & 14.0 & 12.5 & 13.5 \\
\hline $10-17-00$ & 10.9 & 7.9 & 9.6 & nd & nd & 7.3 & 6.8 & 175 & 123 & 168 & 13.5 & 12.0 & 13.0 \\
\hline
\end{tabular}


Appendix 4. Continuous water-quality monitor data and estimated maximum rates of instream metabolic processes at station 01127000 Quinebaug River at Jewett City, Conn.-Continued

[mg/L, milligrams per liter; $\mathrm{P}_{\max }$ (maximum rate of productivity) and $\mathrm{R}_{\max }$ (maximum rate of respiration) in grams of oxygen per cubic meter per hour $\left(\mathrm{g} \mathrm{O}_{2} / \mathrm{m}^{3} / \mathrm{hr}\right.$ ) estimated from diel changes in dissolved oxygen concentrations; $\mu \mathrm{S} / \mathrm{cm}$, microsiemens per centimeter at 25 degrees Celsius; --, data not available due to partial record; nd, not determined due to equipment malfunction or changes in dissolved oxygen concentration that result from rapid changes in streamflow]

\begin{tabular}{|c|c|c|c|c|c|c|c|c|c|c|c|c|c|}
\hline \multirow{2}{*}{ Date } & \multicolumn{3}{|c|}{$\begin{array}{l}\text { Dissolved oxygen } \\
(\mathrm{mg} / \mathrm{L})\end{array}$} & \multicolumn{2}{|c|}{$\begin{array}{l}\text { Productivity/ } \\
\text { respiration }\end{array}$} & \multicolumn{2}{|c|}{$\begin{array}{c}\mathrm{pH} \\
\text { (standard units) }\end{array}$} & \multicolumn{3}{|c|}{$\begin{array}{l}\text { Specific conductance } \\
(\mu \mathrm{S} / \mathrm{cm})\end{array}$} & \multicolumn{3}{|c|}{$\begin{array}{l}\text { Water temperature } \\
\text { (degrees Celsius) }\end{array}$} \\
\hline & Max & Min & Mean & Pmax & $R \max$ & Max & Min & Max & Min & Mean & Max & Min & Mean \\
\hline $10-18-00$ & 10.2 & 7.6 & 9.2 & nd & nd & 7.1 & 6.7 & 182 & 143 & 176 & 13.5 & 12.5 & 13.0 \\
\hline $10-19-00$ & 10.1 & 8.1 & 9.4 & nd & nd & 7.1 & 6.8 & 196 & 139 & 184 & 14.0 & 12.5 & 13.0 \\
\hline $10-20-00$ & 10.8 & 8.7 & 9.6 & nd & nd & 7.1 & 6.8 & 201 & 173 & 190 & 15.0 & 11.5 & 13.0 \\
\hline $10-21-00$ & 11.1 & 8.5 & 9.8 & nd & nd & 7.2 & 6.8 & 202 & 173 & 188 & 15.0 & 12.0 & 12.5 \\
\hline $10-22-00$ & 11.3 & 8.7 & 9.8 & nd & nd & 7.3 & 6.8 & 191 & 133 & 176 & 14.5 & 12.0 & 13.0 \\
\hline $10-23-00$ & 11.1 & 8.7 & 9.9 & nd & nd & 7.2 & 6.7 & 182 & 124 & 171 & 13.0 & 10.5 & 12.0 \\
\hline $10-24-00$ & 11.0 & 8.7 & 9.8 & nd & nd & 7.1 & 6.8 & 182 & 135 & 169 & 12.5 & 10.5 & 12.0 \\
\hline $10-25-00$ & 12.0 & 8.9 & 10.3 & nd & nd & 7.3 & 6.8 & 176 & 155 & 167 & 15.0 & 11.5 & 12.5 \\
\hline $10-26-00$ & 11.9 & 9.0 & 10.2 & nd & nd & 7.3 & 6.8 & 171 & 153 & 163 & 14.5 & 12.0 & 12.5 \\
\hline $10-27-00$ & 11.6 & 8.4 & 10.1 & nd & nd & 7.2 & 6.7 & 164 & 124 & 157 & 14.0 & 12.0 & 13.0 \\
\hline $10-28-00$ & 10.8 & 9.2 & 9.9 & nd & nd & 7.1 & 6.8 & 138 & 94 & 117 & 14.0 & 11.5 & 13.0 \\
\hline $10-29-00$ & 11.1 & 9.8 & 10.5 & nd & nd & 7.1 & 6.8 & 137 & 88 & 113 & 12.0 & 10.0 & 11.0 \\
\hline $10-30-00$ & 11.6 & 10.3 & 10.9 & nd & nd & 7.1 & 6.8 & 134 & 91 & 112 & 10.5 & 9.5 & 10.0 \\
\hline $10-31-00$ & 11.9 & 10.6 & 11.2 & nd & nd & 7.0 & 6.8 & 129 & 86 & 106 & 9.5 & 9.0 & 9.5 \\
\hline $11-01-00$ & 12.4 & 10.7 & 11.5 & nd & nd & -- & 6.7 & 99 & 85 & 90 & 11.0 & 8.5 & 9.5 \\
\hline $11-02-00$ & 12.2 & 11.2 & 11.6 & nd & nd & 7.0 & 6.6 & 140 & 80 & 98 & 11.0 & 8.5 & 9.5 \\
\hline $11-03-00$ & 12.2 & 11.2 & 11.6 & nd & nd & 7.1 & 6.7 & 130 & 91 & 104 & 10.0 & 9.0 & 9.5 \\
\hline $11-04-00$ & 12.2 & 11.1 & 11.7 & nd & nd & 7.0 & 6.7 & 130 & 85 & 113 & 11.0 & 9.0 & 9.5 \\
\hline $11-05-00$ & 12.0 & 10.8 & 11.3 & nd & nd & 6.9 & 6.6 & 132 & 84 & 111 & 9.5 & 9.0 & 9.5 \\
\hline $11-06-00$ & 12.1 & 11.1 & 11.6 & nd & nd & 7.0 & 6.6 & 134 & 92 & 106 & 9.5 & 8.5 & 9.0 \\
\hline $11-07-00$ & 12.6 & 11.4 & 11.9 & nd & nd & 7.0 & 6.7 & 149 & 93 & 110 & 10.0 & 8.5 & 9.0 \\
\hline $11-08-00$ & 12.7 & 11.3 & 11.8 & nd & nd & 7.1 & 6.7 & 138 & 95 & 108 & 10.0 & 8.5 & 9.0 \\
\hline $11-09-00$ & 12.8 & 11.4 & 12.0 & nd & nd & 7.0 & 6.7 & 142 & 97 & 120 & 10.5 & 8.5 & 9.5 \\
\hline $11-10-00$ & 12.1 & 11.1 & 11.6 & nd & nd & 7.0 & 6.7 & 138 & 100 & 120 & 9.5 & 9.5 & 9.5 \\
\hline $11-11-00$ & 12.1 & 11.4 & 11.8 & nd & nd & 7.0 & 6.9 & 149 & 135 & 140 & 9.5 & 9.0 & 9.5 \\
\hline $11-12-00$ & 11.8 & 11.1 & 11.4 & nd & nd & 7.0 & 6.8 & 158 & 143 & 149 & 10.5 & 9.5 & 10.0 \\
\hline $11-13-00$ & 11.5 & 10.5 & 11.1 & nd & nd & 6.8 & 6.7 & 144 & 105 & 131 & 9.5 & 9.5 & 9.5 \\
\hline $11-14-00$ & 11.6 & 10.9 & 11.3 & nd & nd & 6.8 & 6.6 & 153 & 107 & 135 & 10.0 & 9.0 & 9.5 \\
\hline $11-15-00$ & 11.9 & 9.5 & 11.4 & nd & nd & 6.9 & 6.6 & 155 & 120 & 142 & 9.0 & 8.5 & 9.0 \\
\hline $11-16-00$ & 12.1 & 10.8 & 11.4 & nd & nd & -- & -- & 150 & 131 & 138 & 8.5 & 8.0 & 8.5 \\
\hline $11-17-00$ & 11.4 & 9.9 & 11.0 & nd & nd & -- & -- & 140 & 128 & 138 & 8.5 & 7.5 & 8.0 \\
\hline $11-18-00$ & 11.8 & 9.7 & 11.0 & nd & nd & -- & -- & 144 & 133 & 140 & 7.5 & 6.5 & 7.0 \\
\hline $11-19-00$ & 12.5 & 9.8 & 11.4 & nd & nd & -- & -- & 146 & 134 & 141 & 8.5 & 6.5 & 7.0 \\
\hline $11-20-00$ & 11.9 & 10.1 & 11.2 & nd & nd & -- & -- & 146 & 137 & 143 & 6.5 & 5.5 & 6.0 \\
\hline $11-21-00$ & 13.2 & 11.1 & 11.9 & nd & nd & -- & -- & 150 & 139 & 145 & 7.5 & 5.0 & 5.5 \\
\hline $11-22-00$ & 13.0 & 11.1 & 11.9 & nd & nd & -- & -- & 149 & 140 & 146 & 5.0 & 3.5 & 4.5 \\
\hline $11-23-00$ & 14.0 & 11.5 & 12.4 & nd & nd & -- & -- & 147 & 141 & 145 & 6.0 & 3.0 & 4.0 \\
\hline $11-24-00$ & 13.6 & 11.4 & 12.4 & nd & nd & -- & -- & 149 & 140 & 145 & 4.5 & 2.5 & 3.0 \\
\hline $11-25-00$ & 14.3 & 11.5 & 12.8 & nd & nd & -- & -- & 150 & 144 & 148 & 4.0 & 2.5 & 3.0 \\
\hline $11-26-00$ & 13.0 & 10.4 & 11.9 & nd & nd & -- & -- & 155 & 139 & 145 & 3.5 & 2.5 & 3.0 \\
\hline $11-27-00$ & 13.4 & 9.9 & 12.8 & nd & nd & --- & -- & 144 & 128 & 141 & 3.5 & 2.0 & 2.5 \\
\hline $11-28-00$ & 13.2 & 12.4 & 12.9 & nd & nd & -- & -- & 141 & 132 & 137 & 4.0 & 2.5 & 3.0 \\
\hline $11-29-00$ & 12.9 & 11.7 & 12.5 & nd & nd & -- & -- & 133 & 119 & 129 & 4.5 & 4.0 & 4.0 \\
\hline $11-30-00$ & 12.7 & 11.9 & 12.4 & nd & nd & -- & -- & 130 & 115 & 126 & 4.5 & 4.5 & 4.5 \\
\hline $12-01-00$ & 13.0 & 11.8 & 12.5 & nd & nd & -- & -- & 132 & 116 & 128 & 4.5 & 4.0 & 4.0 \\
\hline $12-02-00$ & 13.0 & 12.2 & 12.6 & nd & nd & -- & -- & 135 & 117 & 131 & 4.0 & 3.0 & 3.5 \\
\hline
\end{tabular}


Appendix 4. Continuous water-quality monitor data and estimated maximum rates of instream metabolic processes at station 01127000 , Quinebaug River at Jewett City, Conn.-Continued

[mg/L, milligrams per liter; $\mathrm{P}_{\max }$ (maximum rate of productivity) and $\mathrm{R}_{\max }$ (maximum rate of respiration) in grams of oxygen per cubic meter per hour $\left(\mathrm{g} \mathrm{O}_{2} / \mathrm{m}^{3} / \mathrm{hr}\right.$ ) estimated from diel changes in dissolved oxygen concentrations; $\mu \mathrm{S} / \mathrm{cm}$, microsiemens per centimeter at 25 degrees Celsius; --, data not available due to partial record; nd, not determined due to equipment malfunction or changes in dissolved oxygen concentration that result from rapid changes in streamflow]

\begin{tabular}{|c|c|c|c|c|c|c|c|c|c|c|c|c|c|}
\hline \multirow[t]{2}{*}{ Date } & \multicolumn{3}{|c|}{$\begin{array}{l}\text { Dissolved oxygen } \\
\text { (mg/L) }\end{array}$} & \multicolumn{2}{|c|}{$\begin{array}{l}\text { Productivity/ } \\
\text { respiration }\end{array}$} & \multicolumn{2}{|c|}{$\begin{array}{c}\mathrm{pH} \\
\text { (standard units) }\end{array}$} & \multicolumn{3}{|c|}{$\begin{array}{c}\text { Specific conductance } \\
(\mu \mathrm{S} / \mathrm{cm})\end{array}$} & \multicolumn{3}{|c|}{$\begin{array}{l}\text { Water temperature } \\
\text { (degrees Celsius) }\end{array}$} \\
\hline & Max & Min & Mean & Pmax & Rmax & Max & Min & Max & Min & Mean & Max & Min & Mean \\
\hline $12-03-00$ & 14.0 & 12.5 & 13.0 & nd & nd & -- & -- & 134 & 115 & 130 & 4.0 & 2.5 & 2.5 \\
\hline $12-04-00$ & 13.6 & 12.3 & 13.1 & nd & nd & -- & -- & 136 & 115 & 129 & 4.0 & 2.0 & 2.5 \\
\hline $12-05-00$ & 13.8 & 12.4 & 13.2 & nd & nd & -- & -- & 140 & 120 & 132 & 3.0 & 2.0 & 2.5 \\
\hline $12-06-00$ & 14.3 & 12.6 & 13.5 & nd & nd & -- & -- & 144 & 117 & 132 & 2.5 & 1.5 & 2.0 \\
\hline $12-07-00$ & 14.0 & 12.8 & 13.4 & nd & nd & -- & -- & 143 & 120 & 132 & 3.0 & 1.5 & 2.0 \\
\hline $12-08-00$ & 14.0 & 12.9 & 13.6 & nd & nd & -- & -- & -- & 121 & 137 & 2.5 & 1.5 & 2.0 \\
\hline $04-25-01$ & -- & -- & -- & nd & nd & -- & -- & -- & -- & -- & 17.0 & -- & -- \\
\hline $04-26-01$ & 8.5 & 7.5 & 8.0 & nd & nd & 7.2 & 7.1 & 130 & 138 & 129 & 16.5 & 15.0 & 15.5 \\
\hline $04-27-01$ & 9.8 & 6.9 & 8.0 & nd & nd & 7.2 & 7.1 & 133 & 127 & 131 & 16.0 & 14.0 & 15.0 \\
\hline $04-28-01$ & 9.4 & 7.2 & 8.1 & nd & nd & 7.3 & 7.1 & 134 & 131 & 132 & 16.0 & 14.5 & 15.0 \\
\hline 04-29-01 & 8.6 & 6.7 & 7.8 & nd & nd & 7.3 & 7.2 & 135 & 132 & 134 & 16.0 & 14.5 & 15.0 \\
\hline 04-30-01 & 9.1 & 7.5 & 8.1 & nd & nd & 7.3 & 7.1 & 135 & 131 & 134 & 16.0 & 14.0 & 15.0 \\
\hline $05-01-01$ & 9.2 & 7.6 & 8.3 & nd & nd & 7.2 & 7.1 & 137 & 131 & 134 & 16.5 & 15.0 & 16.0 \\
\hline $05-02-01$ & 8.5 & 7.0 & 7.6 & nd & nd & 7.3 & 7.1 & 142 & 137 & 139 & 19.0 & 16.5 & 17.5 \\
\hline $05-03-01$ & 8.0 & 6.4 & 7.1 & nd & nd & 7.3 & 7.2 & -- & -- & -- & 20.0 & 18.0 & 18.5 \\
\hline $05-04-01$ & 9.8 & 6.2 & 7.6 & nd & nd & 7.2 & 6.7 & -- & -- & -- & 22.0 & 19.0 & 20.0 \\
\hline $05-05-01$ & -- & -- & -- & nd & nd & -- & -- & -- & -- & -- & 22.5 & 19.0 & 21.0 \\
\hline $05-19-01$ & -- & 8.8 & -- & nd & nd & -- & -- & -- & -- & -- & -- & 17.0 & -- \\
\hline $05-20-01$ & 11.4 & 8.6 & 9.8 & nd & nd & 7.5 & 6.6 & 174 & 147 & 163 & 19.5 & 16.0 & 17.0 \\
\hline $05-21-01$ & 11.2 & 8.4 & 9.8 & nd & nd & 7.4 & 6.7 & 173 & 148 & 164 & 19.0 & 15.5 & 17.5 \\
\hline $05-22-01$ & 10.6 & 7.7 & 9.3 & nd & nd & 7.2 & 6.7 & 168 & 133 & 156 & 18.0 & 17.5 & 18.0 \\
\hline $05-23-01$ & 10.0 & 8.1 & 9.3 & nd & nd & 7.0 & 6.7 & 163 & 121 & 148 & 17.5 & 17.0 & 17.5 \\
\hline $05-24-01$ & 9.4 & 8.8 & 9.1 & nd & nd & 6.8 & 6.8 & 149 & 139 & 145 & 17.0 & 16.0 & 16.5 \\
\hline $05-25-01$ & 10.0 & 9.4 & 9.8 & nd & nd & 6.9 & 6.8 & 139 & 120 & 127 & 16.5 & 15.5 & 16.0 \\
\hline $05-26-01$ & 10.2 & 9.9 & 10.0 & nd & nd & 6.9 & 6.8 & 120 & 112 & 118 & 17.0 & 16.0 & 16.5 \\
\hline $05-27-01$ & 10.4 & 9.0 & 10.1 & nd & nd & 6.9 & 6.8 & 120 & 110 & 115 & 18.0 & 16.5 & 17.5 \\
\hline $05-28-01$ & 10.0 & 9.7 & 9.9 & nd & nd & 6.9 & 6.8 & 123 & 109 & 114 & 18.5 & 18.0 & 18.0 \\
\hline $05-29-01$ & 10.0 & 9.7 & 9.8 & nd & nd & 6.8 & 6.8 & 115 & 107 & 111 & 18.5 & 17.5 & 18.0 \\
\hline $05-30-01$ & 10.5 & 9.8 & 10.1 & nd & nd & 7.0 & 6.8 & 120 & 111 & 117 & 19.0 & 18.0 & 18.5 \\
\hline $05-31-01$ & 10.8 & 9.8 & 10.3 & nd & nd & 7.0 & 6.8 & 125 & 118 & 181 & 18.0 & 17.0 & 17.5 \\
\hline $06-01-01$ & 10.8 & 7.7 & 10.3 & nd & nd & 7.0 & 6.6 & 131 & 106 & 125 & 19.0 & 17.0 & 17.5 \\
\hline $06-02-01$ & 10.9 & 10.0 & 10.6 & nd & nd & 7.0 & 6.9 & 131 & 112 & 123 & 18.0 & 17.5 & 18.0 \\
\hline 06-03-01 & 10.5 & 10.1 & 10.3 & nd & nd & 6.9 & 6.8 & 127 & 102 & 113 & 18.0 & 17.5 & 17.5 \\
\hline 06-04-01 & 10.3 & 10.1 & 10.2 & nd & nd & 6.8 & 6.7 & 106 & 99 & 103 & 19.0 & 18.0 & 18.5 \\
\hline $06-05-01$ & 10.5 & 10.2 & 10.3 & nd & nd & 6.8 & 6.7 & 115 & 105 & 111 & 19.0 & 18.0 & 18.5 \\
\hline 06-06-01 & 10.7 & 9.4 & 10.2 & nd & nd & 6.9 & 6.7 & 127 & 114 & 119 & 20.0 & 18.5 & 19.5 \\
\hline 06-07-01 & 10.5 & 8.9 & 10.1 & nd & nd & 6.9 & 6.8 & 127 & 120 & 124 & 21.5 & 19.0 & 20.0 \\
\hline 06-08-01 & 10.7 & 6.0 & 9.9 & nd & nd & 7.1 & 6.6 & 128 & 111 & 123 & 22.0 & 19.5 & 20.5 \\
\hline 06-09-01 & -- & -- & -- & nd & nd & 7.0 & 6.7 & -- & -- & -- & -- & -- & -- \\
\hline $06-10-01$ & -- & -- & -- & nd & nd & 7.1 & 6.7 & -- & -- & -- & -- & -- & -- \\
\hline 06-11-01 & -- & -- & -- & nd & nd & 6.9 & 6.7 & -- & -- & -- & -- & -- & -- \\
\hline $06-12-01$ & -- & -- & -- & nd & nd & 7.0 & 6.7 & -- & -- & -- & -- & -- & -- \\
\hline $06-13-01$ & -- & -- & -- & nd & nd & 6.9 & 6.8 & -- & -- & -- & -- & -- & -- \\
\hline 06-14-01 & -- & -- & -- & nd & nd & 7.0 & 6.8 & -- & -- & -- & -- & -- & -- \\
\hline $06-15-01$ & -- & -- & -- & nd & nd & 7.0 & 6.7 & -- & -- & -- & -- & -- & -- \\
\hline 06-16-01 & -- & -- & -- & nd & nd & 7.0 & 6.7 & -- & -- & -- & -- & -- & -- \\
\hline
\end{tabular}


Appendix 4. Continuous water-quality monitor data and estimated maximum rates of instream metabolic processes at station 01127000 , Quinebaug River at Jewett City, Conn.-Continued

[mg/L, milligrams per liter; $\mathrm{P}_{\max }$ (maximum rate of productivity) and $\mathrm{R}_{\max }$ (maximum rate of respiration) in grams of oxygen per cubic meter per hour $\left(\mathrm{g} \mathrm{O}_{2} / \mathrm{m}^{3} / \mathrm{hr}\right.$ ) estimated from diel changes in dissolved oxygen concentrations; $\mu \mathrm{S} / \mathrm{cm}$, microsiemens per centimeter at 25 degrees Celsius; --, data not available due to partial record; nd, not determined due to equipment malfunction or changes in dissolved oxygen concentration that result from rapid changes in streamflow]

\begin{tabular}{|c|c|c|c|c|c|c|c|c|c|c|c|c|c|}
\hline \multirow{2}{*}{ Date } & \multicolumn{3}{|c|}{$\begin{array}{l}\text { Dissolved oxygen } \\
\text { (mg/L) }\end{array}$} & \multicolumn{2}{|c|}{$\begin{array}{l}\text { Productivity/ } \\
\text { respiration }\end{array}$} & \multicolumn{2}{|c|}{$\begin{array}{c}\mathrm{pH} \\
\text { (standard units) }\end{array}$} & \multicolumn{3}{|c|}{$\begin{array}{l}\text { Specific conductance } \\
(\mu \mathrm{S} / \mathrm{cm})\end{array}$} & \multicolumn{3}{|c|}{$\begin{array}{l}\text { Water temperature } \\
\text { (degrees Celsius) }\end{array}$} \\
\hline & Max & Min & Mean & Pmax & $R \max$ & Max & Min & Max & Min & Mean & Max & Min & Mean \\
\hline 06-17-01 & -- & -- & -- & nd & nd & 6.9 & 6.7 & -- & -- & -- & -- & -- & -- \\
\hline 06-18-01 & -- & -- & -- & nd & nd & 6.8 & 6.6 & -- & -- & -- & -- & -- & -- \\
\hline 06-19-01 & -- & -- & -- & nd & nd & 6.7 & 6.6 & -- & -- & -- & -- & -- & -- \\
\hline 06-20-01 & -- & -- & -- & nd & nd & 6.8 & 6.6 & -- & -- & -- & -- & -- & -- \\
\hline $06-21-01$ & -- & -- & -- & nd & nd & 6.7 & 6.7 & -- & -- & -- & -- & -- & -- \\
\hline 07-06-01 & 9.2 & -- & -- & nd & nd & -- & 6.8 & -- & -- & -- & 25.0 & -- & -- \\
\hline 07-07-01 & 8.6 & 5.8 & 7.5 & nd & nd & 7.2 & 6.9 & 139 & 114 & 129 & 24.0 & 22.0 & 23.0 \\
\hline 07-08-01 & 8.3 & 5.0 & 6.8 & nd & nd & 7.1 & 6.9 & 142 & 116 & 134 & 23.0 & 22.0 & 22.5 \\
\hline 07-09-01 & 8.9 & 4.7 & 7.0 & nd & nd & 7.3 & 6.8 & 143 & 118 & 136 & 24.0 & 22.0 & 23.0 \\
\hline 07-10-01 & 9.0 & 5.1 & 7.3 & nd & nd & 7.3 & 6.8 & 143 & 114 & 135 & 24.0 & 22.0 & 23.0 \\
\hline $07-11-01$ & 9.7 & 5.3 & 7.6 & nd & nd & 8.0 & 6.9 & 143 & 122 & 139 & 25.0 & 23.0 & 24.0 \\
\hline $07-12-01$ & 8.7 & 4.4 & 7.7 & nd & nd & 7.3 & 6.9 & 145 & 114 & 139 & 24.5 & 22.5 & 23.5 \\
\hline 07-13-01 & 8.7 & 5.0 & 7.6 & nd & nd & 7.3 & 6.9 & 146 & 113 & 137 & 24.5 & 22.0 & 23.0 \\
\hline 07-14-01 & 9.2 & 5.4 & 7.4 & nd & nd & 7.5 & 6.8 & 145 & 117 & 134 & 24.5 & 21.5 & 23.0 \\
\hline $07-15-01$ & 9.7 & 5.2 & 7.6 & nd & nd & 7.9 & 6.8 & 148 & 122 & 136 & 25.5 & 21.5 & 23.0 \\
\hline 07-16-01 & 9.6 & 5.1 & 6.9 & nd & nd & 7.6 & 6.8 & 149 & 124 & 139 & 25.5 & 22.0 & 23.5 \\
\hline $07-17-01$ & 8.9 & 4.7 & 6.6 & nd & nd & 7.4 & 6.7 & 151 & 127 & 142 & 23.5 & 22.5 & 23.0 \\
\hline 07-18-01 & 10.0 & 4.8 & 7.9 & nd & nd & 7.8 & 6.8 & 152 & 120 & 139 & 26.0 & 22.5 & 23.5 \\
\hline 07-19-01 & 9.9 & 5.5 & 8.2 & nd & nd & 7.6 & 6.8 & 154 & 129 & 141 & 25.5 & 22.5 & 23.5 \\
\hline 07-20-01 & 11.2 & 5.3 & 7.7 & nd & nd & 8.4 & 6.8 & 154 & 132 & 145 & 25.5 & 21.5 & 23.5 \\
\hline $07-21-01$ & 10.2 & 6.5 & 8.6 & nd & nd & 8.4 & 6.9 & 160 & 138 & 148 & 27.0 & 22.0 & 23.5 \\
\hline 07-22-01 & 11.4 & 5.3 & 8.2 & nd & nd & 8.9 & 6.8 & 160 & 141 & 150 & 26.0 & 21.5 & 23.5 \\
\hline 07-23-01 & 10.8 & 6.4 & 8.7 & nd & nd & 9.0 & 6.9 & 160 & 142 & 151 & 27.5 & 22.5 & 24.5 \\
\hline $07-24-01$ & 10.5 & 6.9 & 9.0 & nd & nd & 9.1 & 7.1 & 163 & 147 & 155 & 28.0 & 23.5 & 25.5 \\
\hline $07-25-01$ & 10.2 & 6.8 & 8.5 & nd & nd & 9.4 & 7.2 & 167 & 149 & 157 & 29.0 & 24.5 & 26.5 \\
\hline 07-26-01 & 10.0 & 6.1 & 7.7 & nd & nd & 9.5 & 7.2 & 165 & 129 & 146 & 26.0 & 24.5 & 25.5 \\
\hline $07-27-01$ & 9.8 & 6.8 & 7.8 & nd & nd & 9.3 & 7.1 & 163 & 126 & 137 & 27.0 & 23.0 & 25.0 \\
\hline 07-28-01 & 8.9 & 6.5 & 7.5 & nd & nd & 8.7 & 6.9 & 165 & 129 & 142 & 26.5 & 23.0 & 24.0 \\
\hline 07-29-01 & 8.9 & 6.2 & 7.3 & nd & nd & 7.5 & 6.9 & 170 & 135 & 144 & 26.0 & 22.5 & 23.5 \\
\hline $07-30-01$ & 9.0 & 5.8 & 7.3 & nd & nd & 7.6 & 6.8 & 170 & 141 & 150 & 27.0 & 22.0 & 24.0 \\
\hline $07-31-01$ & 9.2 & 5.5 & 7.1 & nd & nd & 8.3 & 6.9 & 175 & 147 & 156 & 26.0 & 22.0 & 24.0 \\
\hline 08-01-01 & 8.6 & 5.8 & 7.0 & nd & nd & 7.8 & 6.8 & 183 & 155 & 163 & 28.0 & 22.0 & 24.0 \\
\hline $08-02-01$ & -- & 5.6 & -- & nd & nd & -- & 6.9 & -- & 158 & -- & -- & 23.0 & -- \\
\hline $08-15-01$ & 8.9 & -- & -- & nd & nd & 7.1 & 6.8 & 141 & 109 & 127 & 24.5 & 23.0 & -- \\
\hline 08-16-01 & 9.1 & 4.5 & 7.2 & nd & nd & 7.1 & 6.7 & 138 & 110 & 128 & 25.5 & 23.0 & 23.5 \\
\hline 08-17-01 & 8.8 & 4.1 & 7.3 & nd & nd & 7.1 & 6.7 & 132 & 112 & 123 & 25.5 & 23.0 & 24.0 \\
\hline 08-18-01 & 9.2 & 3.5 & 6.7 & nd & nd & 7.3 & 6.6 & 134 & 118 & 126 & 26.0 & 23.5 & 24.5 \\
\hline 08-19-01 & 8.8 & 5.0 & 7.2 & nd & nd & 7.1 & 6.7 & 143 & 124 & 132 & 26.5 & 23.5 & 24.5 \\
\hline 08-20-01 & 9.1 & 4.1 & 6.6 & nd & nd & 7.4 & 6.7 & 144 & 96 & 132 & 25.5 & 24.0 & 24.5 \\
\hline 08-21-01 & 9.0 & 5.1 & 7.1 & nd & nd & 7.4 & 6.8 & 136 & 96 & 115 & 26.0 & 24.5 & 25.0 \\
\hline $08-22-01$ & 8.8 & 5.5 & 7.2 & nd & nd & 7.4 & 6.8 & 142 & 98 & 119 & 26.5 & 24.5 & 25.0 \\
\hline 08-23-01 & 8.3 & 5.3 & 7.0 & nd & nd & 7.2 & 6.8 & 147 & 105 & 122 & 26.5 & 24.5 & 25.0 \\
\hline 08-24-01 & 9.6 & 4.3 & 6.6 & nd & nd & 8.2 & 6.7 & 148 & 106 & 124 & 26.5 & 24.5 & 25.0 \\
\hline $08-25-01$ & 8.6 & 5.0 & 6.6 & nd & nd & 7.3 & 6.6 & 152 & 117 & 128 & 27.0 & 23.5 & 25.0 \\
\hline 08-26-01 & 8.0 & 4.5 & 6.5 & nd & nd & 7.1 & 6.6 & 157 & 123 & 135 & 26.5 & 23.0 & 24.5 \\
\hline $08-27-01$ & 8.1 & 3.0 & 5.9 & nd & nd & 7.1 & 6.6 & 165 & 130 & 144 & 25.5 & 23.0 & 24.0 \\
\hline
\end{tabular}


Appendix 4. Continuous water-quality monitor data and estimated maximum rates of instream metabolic processes at station 01127000 , Quinebaug River at Jewett City, Conn.-Continued

$\left[\mathrm{mg} / \mathrm{L}\right.$, milligrams per liter; $\mathrm{P}_{\max }$ (maximum rate of productivity) and $\mathrm{R}_{\max }$ (maximum rate of respiration) in grams of oxygen per cubic meter per hour $\left(\mathrm{g} \mathrm{O}_{2} / \mathrm{m}^{3} / \mathrm{hr}\right.$ ) estimated from diel changes in dissolved oxygen concentrations; $\mu \mathrm{S} / \mathrm{cm}$, microsiemens per centimeter at 25 degrees Celsius; --, data not available due to partial record; nd, not determined due to equipment malfunction or changes in dissolved oxygen concentration that result from rapid changes in streamflow]

\begin{tabular}{|c|c|c|c|c|c|c|c|c|c|c|c|c|c|}
\hline \multirow{2}{*}{ Date } & \multicolumn{3}{|c|}{$\begin{array}{l}\text { Dissolved oxygen } \\
\text { (mg/L) }\end{array}$} & \multicolumn{2}{|c|}{$\begin{array}{l}\text { Productivity/ } \\
\text { respiration }\end{array}$} & \multicolumn{2}{|c|}{$\begin{array}{c}\mathrm{pH} \\
\text { (standard units) }\end{array}$} & \multicolumn{3}{|c|}{$\begin{array}{l}\text { Specific conductance } \\
(\mu \mathrm{S} / \mathrm{cm})\end{array}$} & \multicolumn{3}{|c|}{$\begin{array}{l}\text { Water temperature } \\
\text { (degrees Celsius) }\end{array}$} \\
\hline & Max & Min & Mean & Pmax & $R \max$ & Max & Min & Max & Min & Mean & Max & Min & Mean \\
\hline $08-28-01$ & 8.2 & 2.8 & 5.8 & nd & nd & 7.3 & 6.7 & 155 & 136 & 145 & 27.0 & 24.0 & 25.0 \\
\hline 08-29-01 & 8.0 & 5.5 & 6.8 & nd & nd & 7.4 & 6.9 & 159 & 149 & 153 & 27.0 & 23.5 & 25.0 \\
\hline 08-30-01 & 8.3 & 5.1 & 6.8 & nd & nd & 7.5 & 6.9 & 168 & 154 & 159 & 26.5 & 23.5 & 24.5 \\
\hline 08-31-01 & 8.2 & 4.3 & 6.3 & nd & nd & 7.2 & 6.8 & 177 & 163 & 166 & 26.0 & 23.5 & 24.5 \\
\hline 09-01-01 & 8.2 & 2.5 & 5.5 & 0.60 & -0.54 & 7.2 & 6.7 & 175 & 161 & 167 & 26.5 & 23.5 & 24.5 \\
\hline 09-02-01 & 8.6 & 3.6 & 6.4 & 1.34 & -.44 & 7.6 & 6.7 & 173 & 160 & 167 & 26.0 & 22.0 & 23.5 \\
\hline 09-03-01 & 8.2 & 4.7 & 6.3 & .87 & .36 & 7.2 & 6.7 & 169 & 163 & 166 & 25.5 & 21.5 & 23.0 \\
\hline 09-04-01 & 8.5 & 3.6 & 6.4 & .53 & -.59 & 7.4 & 6.7 & 174 & 162 & 168 & 24.5 & 21.0 & 22.5 \\
\hline 09-05-01 & 9.6 & 4.1 & 6.8 & .43 & -.38 & 7.7 & 6.7 & 177 & 164 & 169 & 25.0 & 21.0 & 22.5 \\
\hline 09-06-01 & 10.0 & 5.9 & 7.7 & nd & -.49 & 7.9 & 7.0 & 180 & 157 & 171 & 25.5 & 20.5 & 22.0 \\
\hline 09-07-01 & 9.6 & 5.9 & 7.8 & .70 & -.54 & 7.6 & 7.0 & 186 & 174 & 178 & 24.5 & 20.5 & 22.0 \\
\hline 09-08-01 & 9.7 & 5.6 & 7.4 & .50 & -.51 & 7.7 & 6.9 & 188 & 180 & 183 & 24.5 & 20.5 & 22.0 \\
\hline 09-09-01 & 9.5 & 5.2 & 7.3 & .68 & nd & 7.6 & 6.9 & 197 & 180 & 187 & 25.0 & 21.0 & 22.5 \\
\hline 09-10-01 & 9.5 & 5.4 & 7.2 & .53 & -.37 & 7.6 & 6.9 & 193 & 183 & 188 & 25.0 & 21.5 & 23.0 \\
\hline 09-11-01 & 10.6 & 5.6 & 7.8 & 1.13 & -.37 & 9.2 & 6.9 & 192 & 178 & 183 & 26.0 & 22.0 & 23.5 \\
\hline 09-12-01 & 10.8 & 5.5 & 8.1 & .43 & -.79 & 9.4 & 7.4 & 193 & 184 & 187 & 26.0 & 21.5 & 23.0 \\
\hline 09-13-01 & 10.1 & 5.4 & 7.8 & .71 & -.42 & 9.1 & 7.5 & 195 & 187 & 190 & 25.5 & 21.0 & 23.0 \\
\hline 09-14-01 & 9.0 & 4.0 & 7.5 & .84 & -.42 & 8.6 & 7.3 & 194 & 183 & 187 & 22.0 & 20.0 & 21.0 \\
\hline $09-15-01$ & 10.6 & 6.1 & 8.3 & nd & -.54 & 8.8 & 7.1 & 195 & 185 & 189 & 23.0 & 19.0 & 20.5 \\
\hline 09-16-01 & 10.4 & 6.3 & 8.2 & .77 & -.53 & 8.4 & 7.2 & 202 & 191 & 194 & 23.5 & 19.0 & 20.5 \\
\hline 09-17-01 & 10.9 & 5.5 & 8.1 & 1.53 & -.40 & 8.3 & 7.1 & 197 & 194 & 195 & 23.0 & 18.5 & 20.0 \\
\hline 09-18-01 & 11.3 & 6.0 & 8.6 & .84 & -.52 & 8.3 & 7.1 & 198 & 193 & 195 & 23.5 & 18.5 & 20.5 \\
\hline 09-19-01 & 11.0 & 5.7 & 8.1 & .53 & -.61 & 8.9 & 7.0 & 206 & 195 & 198 & 23.5 & 19.0 & 20.5 \\
\hline 09-20-01 & 9.8 & 3.9 & 7.3 & 1.72 & -.37 & 7.7 & 6.9 & 211 & 196 & 202 & 21.0 & 19.0 & 20.0 \\
\hline 09-21-01 & 8.8 & 5.9 & 7.3 & nd & nd & 7.3 & 6.9 & 209 & 168 & 186 & 21.0 & 19.5 & 20.0 \\
\hline $09-22-01$ & 9.7 & 6.8 & 8.1 & nd & nd & 7.9 & 7.1 & 175 & 167 & 171 & 22.0 & 20.0 & 20.5 \\
\hline 09-23-01 & 9.8 & 7.2 & 8.3 & nd & nd & 8.8 & 7.3 & 171 & 160 & 168 & 23.5 & 20.5 & 21.5 \\
\hline 09-24-01 & 10.1 & 4.7 & 7.8 & nd & nd & 8.6 & 7.0 & 203 & 162 & 175 & 22.0 & 21.0 & 21.0 \\
\hline 09-25-01 & 9.1 & 4.6 & 6.6 & nd & nd & 7.4 & 6.9 & 183 & 162 & 171 & -- & -- & -- \\
\hline
\end{tabular}


Nutrient Enrichment, Phytoplankton Algal Growth, and Rates of Metabolism in the Quinebaug River Basin, Conn.

Appendix 5 
Appendix 5. Seston algal abundance by taxa in water samples collected from the Quinebaug River Basin, Connecticut, water years 2000 and 2001.

[Algal identification and enumeration of all samples was performed by Connecticut Department of Environmental Protection using Sedgwick-Rafter cell count as per American Public Health Association, 1992; numbers may not add to totals because of independent rounding. Bacillariophyceae, centric, pennate, and other diatoms; Chlorophyceae, flagellated, filamentous and non-filamentous green algae;

Chrysophyceae, gold, brown, and gold-brown pigmented algae; Cyanophyceae, filamentous and non-filamentous blue-green algae (currently considered to be bacteria due to lack of a distinct cellular nucleus); Dinophyceae, dinoflagellates]

\begin{tabular}{|c|c|c|c|c|c|c|c|}
\hline \multirow{2}{*}{$\begin{array}{l}\text { Station } \\
\text { name }\end{array}$} & \multirow{2}{*}{ Date } & \multicolumn{6}{|c|}{ Taxon and density (algal cells per milliliter), rounded } \\
\hline & & Bacillariophyceae & Chlorophyceae & Chrysophyceae & Cyanophyceae & Dinophyceae & Total algal count \\
\hline \multirow{6}{*}{$\begin{array}{l}\text { Quinebaug River at } \\
\text { Quinebaug, Conn. }\end{array}$} & $05 / 22 / 2000$ & 140 & 0 & 0 & 0 & 0 & 140 \\
\hline & $07 / 24 / 2000$ & 70 & 0 & 0 & 0 & 0 & 70 \\
\hline & $09 / 26 / 2000$ & 0 & 0 & 0 & 0 & 0 & 0 \\
\hline & $06 / 11 / 2001$ & 70 & 0 & 0 & 210 & 0 & 280 \\
\hline & $08 / 6 / 2001$ & 70 & 0 & 0 & 0 & 0 & 70 \\
\hline & 09/10/2001 & 140 & 0 & 0 & 0 & 0 & 140 \\
\hline \multirow{6}{*}{$\begin{array}{l}\text { Quinebaug River at } \\
\text { West Thompson, Conn. }\end{array}$} & $05 / 22 / 2000$ & 910 & 0 & 0 & 0 & 0 & 910 \\
\hline & $07 / 24 / 2000$ & 70 & 2,200 & 0 & 2,000 & 140 & 4,400 \\
\hline & $09 / 26 / 2000$ & 2,900 & 0 & 0 & 1,100 & 0 & 4,000 \\
\hline & $06 / 11 / 2001$ & 280 & 0 & 0 & 1,300 & 0 & 1,600 \\
\hline & 08/06/2001 & 1,200 & 3,900 & 0 & 13,000 & 0 & 18,000 \\
\hline & 09/10/2001 & 770 & 1,800 & 0 & 19,000 & 70 & 22,000 \\
\hline \multirow{6}{*}{$\begin{array}{l}\text { French River near } \\
\text { North Grosvenordale, } \\
\text { Conn. }\end{array}$} & $05 / 22 / 2000$ & 490 & 0 & 0 & 70 & 0 & 560 \\
\hline & $07 / 24 / 2000$ & 210 & 1,900 & 0 & 0 & 0 & 2,100 \\
\hline & $09 / 26 / 2000$ & 7,700 & 840 & 0 & 420 & 0 & 9,000 \\
\hline & $06 / 11 / 2001$ & 0 & 0 & 0 & 630 & 0 & 630 \\
\hline & 08/06/2001 & 350 & 210 & 0 & 420 & 70 & 1,100 \\
\hline & 09/10/2001 & 280 & 1,200 & 0 & 8,000 & 0 & 9,500 \\
\hline \multirow{6}{*}{$\begin{array}{l}\text { Little River at } \\
\text { Putnam, Conn. }\end{array}$} & $05 / 23 / 2000$ & 630 & 0 & 0 & 0 & 0 & 630 \\
\hline & $07 / 25 / 2000$ & 420 & 0 & 0 & 61,000 & 70 & 62,000 \\
\hline & $09 / 26 / 2000$ & 0 & 1,200 & 350 & 0 & 0 & 1,500 \\
\hline & $06 / 12 / 2001$ & 1,300 & 140 & 0 & 1,100 & 0 & 2,500 \\
\hline & 080/6/2001 & 840 & 0 & 0 & 0 & 0 & 840 \\
\hline & 09/11/2001 & 140 & 210 & 0 & 210 & 0 & 560 \\
\hline \multirow{6}{*}{$\begin{array}{l}\text { Quinebaug River at } \\
\text { Putnam, Conn. }\end{array}$} & $05 / 23 / 2000$ & 630 & 560 & 0 & 0 & 0 & 1,200 \\
\hline & $07 / 25 / 2000$ & 140 & 1,300 & 0 & 2,500 & 0 & 4,000 \\
\hline & 09/27/2000 & 2,500 & 1,300 & 0 & 0 & 0 & 3,800 \\
\hline & $06 / 12 / 2001$ & 210 & 420 & 0 & 910 & 0 & 1,500 \\
\hline & 08/07/2001 & 350 & 70 & 0 & 1,500 & 0 & 1,900 \\
\hline & 09/11/2001 & 280 & 2,500 & 0 & 15,000 & 70 & 18,000 \\
\hline
\end{tabular}


[Algal identification and enumeration of all samples was performed by Connecticut Department of Environmental Protection using Sedgwick-Rafter cell count as per American Public Health Association, 1992; numbers may not add to totals because of independent rounding. Bacillariophyceae, centric, pennate, and other diatoms; Chlorophyceae, flagellated, filamentous and non-filamentous green algae;

Chrysophyceae, gold, brown, and gold-brown pigmented algae; Cyanophyceae, filamentous and non-filamentous blue-green algae (currently considered to be bacteria due to lack of a distinct cellular nucleus); Dinophyceae, dinoflagellates]

\begin{tabular}{|c|c|c|c|c|c|c|c|}
\hline \multirow{2}{*}{$\begin{array}{l}\text { Station } \\
\text { name }\end{array}$} & \multirow{2}{*}{ Date } & \multicolumn{6}{|c|}{ Taxon and density (algal cells per milliliter), rounded } \\
\hline & & Bacillariophyceae & Chlorophyceae & Chrysophyceae & Cyanophyceae & Dinophyceae & Total algal count \\
\hline \multirow{7}{*}{$\begin{array}{l}\text { Quinebaug River at } \\
\text { Cotton Bridge Rd. near } \\
\text { Pomfret Landing, Conn. }\end{array}$} & $05 / 23 / 2000$ & 0 & 0 & 0 & 0 & 0 & 0 \\
\hline & $07 / 26 / 2000$ & 280 & 3,200 & 0 & 8,400 & 0 & 12,000 \\
\hline & $08 / 23 / 2000$ & 560 & 0 & 0 & 0 & 0 & 560 \\
\hline & $09 / 27 / 2000$ & 700 & 420 & 0 & 70 & 0 & 1,200 \\
\hline & $06 / 12 / 2001$ & 700 & 70 & 0 & 840 & 0 & 1,600 \\
\hline & 08/07/2001 & 140 & 70 & 0 & 2,000 & 0 & 2,200 \\
\hline & 09/12/2001 & 210 & 1,200 & 0 & 24,000 & 0 & 25,000 \\
\hline \multirow{6}{*}{$\begin{array}{l}\text { Five Mile River at } \\
\text { Danielson, Conn. }\end{array}$} & $05 / 24 / 2000$ & 70 & 0 & 0 & 0 & 0 & 70 \\
\hline & $07 / 26 / 2000$ & 0 & 560 & 0 & 0 & 0 & 560 \\
\hline & $08 / 23 / 2000$ & 0 & 0 & 0 & 0 & 0 & 0 \\
\hline & $09 / 28 / 2000$ & 0 & 0 & 0 & 0 & 0 & 0 \\
\hline & 08/08/2001 & 0 & 0 & 0 & 70 & 0 & 70 \\
\hline & 09/12/2001 & 0 & 0 & 0 & 0 & 0 & 0 \\
\hline \multirow{7}{*}{$\begin{array}{l}\text { Quinebaug River at } \\
\text { Danielson, Conn. }\end{array}$} & $05 / 24 / 2000$ & 630 & 280 & 0 & 0 & 0 & 910 \\
\hline & 07/26/2000 & 560 & 1,300 & 0 & 0 & 0 & 1,900 \\
\hline & $08 / 23 / 2000$ & 70 & 70 & 0 & 0 & 0 & 140 \\
\hline & $09 / 28 / 2000$ & 0 & 70 & 0 & 47,000 & 0 & 47,000 \\
\hline & 06/13/2001 & 420 & 0 & 70 & 1,100 & 0 & 1,600 \\
\hline & 08/08/2001 & 350 & 70 & 0 & 2,500 & 0 & 2,900 \\
\hline & $09 / 12 / 2001$ & 1,100 & 5,200 & 0 & 71,000 & 0 & 77,000 \\
\hline \multirow{6}{*}{$\begin{array}{l}\text { Moosup River at } \\
\text { Plainfield, Conn. }\end{array}$} & $05 / 24 / 2000$ & 490 & 0 & 0 & 0 & 0 & 490 \\
\hline & 07/26/2000 & 0 & 0 & 0 & 0 & 0 & 0 \\
\hline & $08 / 24 / 2000$ & 140 & 0 & 0 & 0 & 0 & 140 \\
\hline & $09 / 28 / 2000$ & 70 & 0 & 0 & 0 & 0 & 70 \\
\hline & 08/09/2001 & 140 & 0 & 0 & 0 & 0 & 140 \\
\hline & 09/13/2001 & 0 & 0 & 0 & 0 & 0 & 0 \\
\hline
\end{tabular}


Appendix 5. Seston algal abundance by taxa in water samples collected from the Quinebaug River Basin, Connecticut, water years 2000 and 2001.—Continued

[Algal identification and enumeration of all samples was performed by Connecticut Department of Environmental Protection using Sedgwick-Rafter cell count as per American Public Health Association, 1992; numbers may not add to totals because of independent rounding. Bacillariophyceae, centric, pennate, and other diatoms; Chlorophyceae, flagellated, filamentous and non-filamentous green algae;

Chrysophyceae, gold, brown, and gold-brown pigmented algae; Cyanophyceae, filamentous and non-filamentous blue-green algae (currently considered to be bacteria due to lack of a distinct cellular nucleus); Dinophyceae, dinoflagellates]

\begin{tabular}{|c|c|c|c|c|c|c|c|}
\hline \multirow{2}{*}{$\begin{array}{c}\text { Station } \\
\text { name }\end{array}$} & \multirow{2}{*}{ Date } & \multicolumn{6}{|c|}{ Taxon and density (algal cells per milliliter), rounded } \\
\hline & & Bacillariophyceae & Chlorophyceae & Chrysophyceae & Cyanophyceae & Dinophyceae & Total algal count \\
\hline \multirow{7}{*}{$\begin{array}{l}\text { Quinebaug River at } \\
\text { Butts Bridge Rd. near } \\
\text { Clayville, Conn. }\end{array}$} & $05 / 25 / 2000$ & 420 & 0 & 70 & 0 & 0 & 490 \\
\hline & $07 / 27 / 2000$ & 0 & 910 & 0 & 0 & 0 & 910 \\
\hline & $08 / 24 / 2000$ & 140 & 70 & 0 & 0 & 0 & 210 \\
\hline & $09 / 29 / 2000$ & 700 & 280 & 0 & 0 & 0 & 980 \\
\hline & $06 / 14 / 2001$ & 770 & 0 & 0 & 770 & 0 & 1,500 \\
\hline & $08 / 09 / 2001$ & 0 & 6,200 & 0 & 8,900 & 0 & 15,000 \\
\hline & 09/13/2001 & 70 & 490 & 0 & 85,000 & 0 & 85,000 \\
\hline \multirow{7}{*}{$\begin{array}{l}\text { Pachaug River at } \\
\text { Jewett City, Conn. }\end{array}$} & $05 / 25 / 2000$ & 0 & 280 & 0 & 0 & 0 & 280 \\
\hline & $07 / 27 / 2000$ & 1,500 & 0 & 0 & 2,500 & 0 & 4,000 \\
\hline & $08 / 25 / 2000$ & 70 & 0 & 0 & 0 & 140 & 210 \\
\hline & $09 / 29 / 2000$ & 0 & 0 & 70 & 70 & 0 & 140 \\
\hline & $06 / 14 / 2001$ & 560 & 420 & 140 & 840 & 0 & 2,000 \\
\hline & 08/09/2001 & 910 & 140 & 0 & 8,800 & 0 & 9,800 \\
\hline & $09 / 13 / 2001$ & 70 & 0 & 0 & 2,200 & 0 & 2,300 \\
\hline \multirow{7}{*}{$\begin{array}{l}\text { Quinebaug River at } \\
\text { Jewett City, Conn. }\end{array}$} & $05 / 25 / 2000$ & 700 & 280 & 0 & 0 & 0 & 980 \\
\hline & $07 / 27 / 2000$ & 1,600 & 2,700 & 0 & 560 & 0 & 4,900 \\
\hline & $08 / 25 / 2000$ & 1,800 & 0 & 0 & 0 & 0 & 1,800 \\
\hline & $09 / 28 / 2000$ & 1,100 & 420 & 0 & 280 & 0 & 1,800 \\
\hline & $06 / 15 / 2001$ & 1,200 & 280 & 0 & 1,900 & 0 & 3,400 \\
\hline & 08/10/2001 & 2,100 & 140 & 0 & 19,000 & 0 & 21,000 \\
\hline & 09/14/2001 & 1,900 & 420 & 0 & 56,000 & 0 & 59,000 \\
\hline
\end{tabular}


